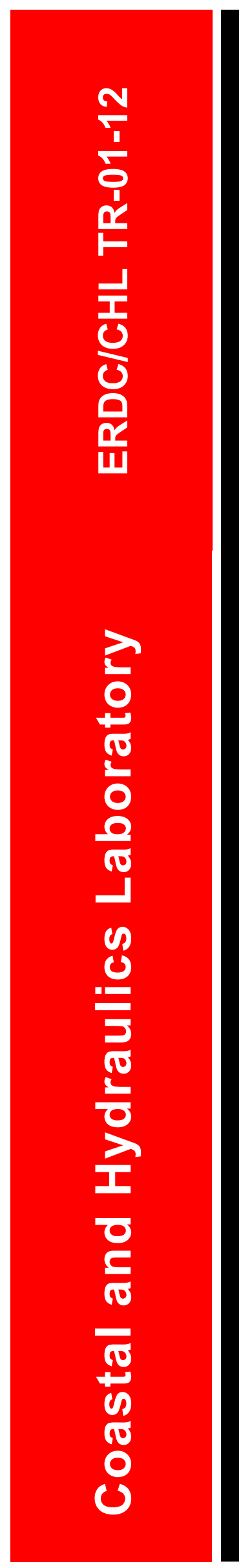

Beach Erosion and Sediment Processes Study, North East Marina, Erie County, Pennsylvania

Andrew Morang and Jeffrey Melton

June 2001 
The contents of this report are not to be used for advertising, publication, or promotional purposes. Citation of trade names does not constitute an official endorsement or approval of the use of such commercial products.

The findings of this report are not to be construed as an official Department of the Army position, unless so designated by other authorized documents. 


\section{Beach Erosion and Sediment Processes Study, North East Marina, Erie County, Pennsylvania}

by Andrew Morang, Jeffrey Melton

Coastal and Hydraulics Laboratory

U.S. Army Engineer Research and Development Center

3909 Halls Ferry Road

Vicksburg, MS 39180-6199

Final report

Approved for public release; distribution is unlimited 


\section{Contents}

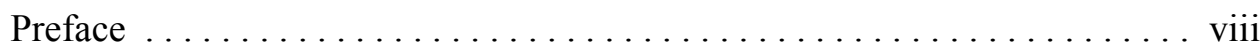

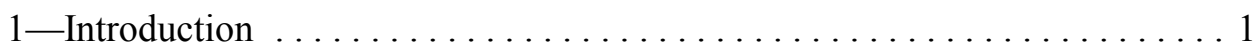

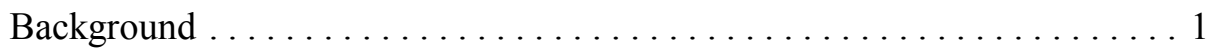

Study Objectives and Study Plan $\ldots \ldots \ldots \ldots \ldots \ldots \ldots \ldots \ldots \ldots \ldots \ldots \ldots \ldots$

2 - Study Area and Physical Setting $\ldots \ldots \ldots \ldots \ldots \ldots \ldots \ldots \ldots \ldots \ldots \ldots \ldots \ldots \ldots$

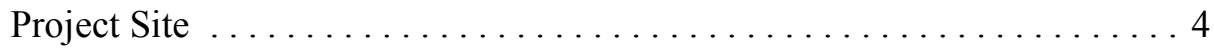

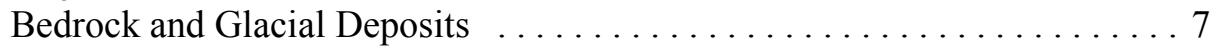

Wave Climate . . . . . . . . . . . . . . . . . . . . 13

Lake Level ............................. 18

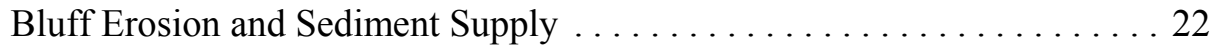

Manmade Structures . . . . . . . . . . . . . . . . . . 28

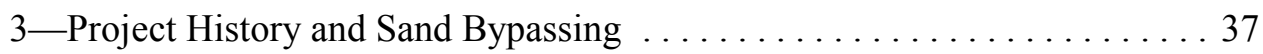

4-September 1999 Field Study $\ldots \ldots \ldots \ldots \ldots \ldots \ldots \ldots \ldots \ldots \ldots \ldots$

Side-Scan Sonar $\ldots \ldots \ldots \ldots \ldots \ldots \ldots \ldots \ldots \ldots \ldots \ldots \ldots \ldots . \ldots \ldots$

Diver, Video, and Visual Observation $\ldots \ldots \ldots \ldots \ldots \ldots \ldots \ldots \ldots 4$

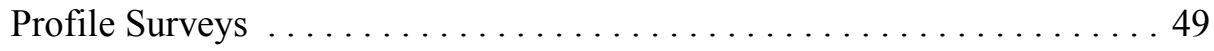

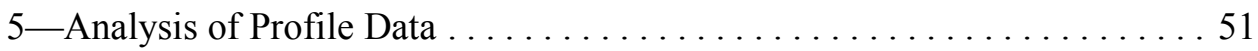

Procedure Used to Compute Profile Volumes $\ldots \ldots \ldots \ldots \ldots \ldots \ldots$. . . . 51

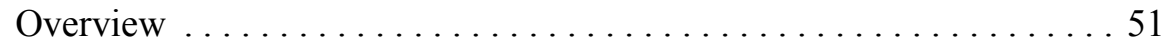

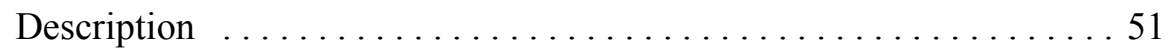

Limits used for volume computations $\ldots \ldots \ldots \ldots \ldots \ldots \ldots \ldots$

Results - Profile Volumes Based on Topographic Surveys . . . . . . . . 55

6-Summary of Geological and Physical Process Findings $\ldots \ldots \ldots \ldots 60$ 
7-Sediment Management Alternatives at North East Marina . . . . . . . 63

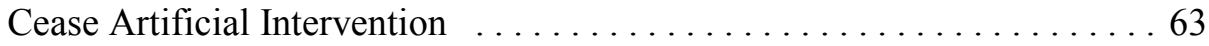

Change Geometry of Shore or Structures . . . . . . . . . . . 66

Alter the marina ............................66 66

Addition of fixed structures . . . . . . . . . . . . . . . 67

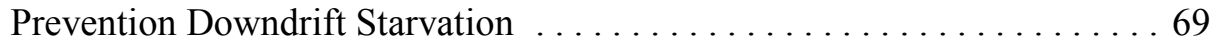

External beach fill ........................... 69

Sand bypassing options using material from west beach fillet

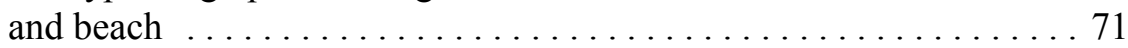

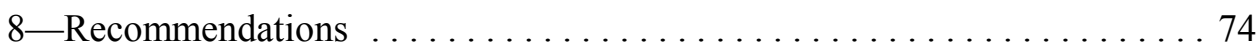

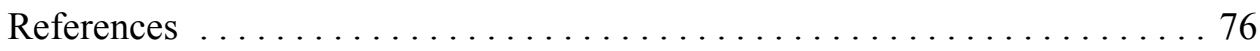

Appendix A: Chronological List of Events and Engineering Activities ... A1

Appendix B: Inventory of Site Photographs $\ldots \ldots \ldots \ldots \ldots \ldots \ldots \ldots$ B1

Appendix C: Inventory of Topographic Profile Surveys $\ldots \ldots \ldots \ldots \ldots$ C1

Appendix D: Profile Survey Procedures and Establishment of Baseline .... D1

Appendix E: Field Notes from 10 October 1999 Data Collection Effort . . . . E1

SF 298

\section{List of Figures}

Figure 1. Study area, Lake Erie $\ldots \ldots \ldots \ldots \ldots \ldots \ldots \ldots \ldots \ldots$

Figure 2. Physical features of North East Marina study site and surrounding area $\ldots \ldots \ldots \ldots \ldots \ldots \ldots \ldots \ldots \ldots \ldots \ldots \ldots \ldots$

Figure 3. Topographic map of Lake Erie shore west of the study area, near Erie, PA ....................... 7

Figure 4. Topographic map of Lake Erie shore west of North East, PA, with $1-\mathrm{km}$ reaches used for shoreline erosion statistics $\ldots \ldots .8$

Figure 5. Lake Erie shore. Reaches 141, 142, and 143 span the North East Marina study area $\ldots \ldots \ldots \ldots \ldots \ldots \ldots \ldots$

Figure 6. Oblique aerial photograph of marina looking southeast, April 1999 ................................ 10 
Figure 7. Vertical aerial photograph, October $15,1999 \ldots \ldots \ldots \ldots 11$

Figure 8. Spilling waves on west side of North East Marina, 22 September 1999 ....................... 15

Figure 9. Ice armor along beach, 29 January $1999 \ldots \ldots \ldots \ldots$

Figure 10. Mean monthly water temperature, averaged from daily readings at the Buffalo, NY, water intake . . . . . . . . . . . . . 17

Figure 11. Mean annual Lake Erie water level from 1865 to present with high-low range shown with vertical bars $\ldots \ldots \ldots \ldots \ldots 20$

Figure 12. Lake Erie monthly mean water level, $1988-2001 \ldots \ldots \ldots \ldots 21$

Figure 13. Sand beach west of Twentymile Creek, 1 August 1999 . . . . . 22

Figure 14. Best fit curve and modeled beach profile for Profile line E1800.

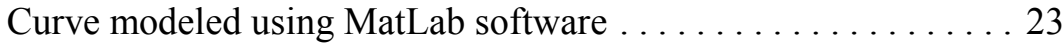

Figure 15. Variation of beach width at Profile Line E1800 corresponding to water level changes during the 1990 s . . . . . . . . . . . 24

Figure 16. Armoring structures along the shore east of North East Marina . . 29

Figure 17. Concrete block wall about 200 m east of marina, 17 May 1991 . . 30

Figure 18. Exposed seawall March 1991, view east ............. 31

Figure 19. House protected with gabions, concrete, and concrete-filled

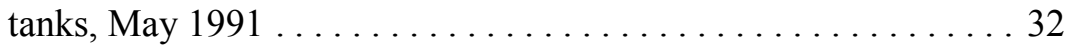

Figure 20. Gravel and sand beach below same structures shown in

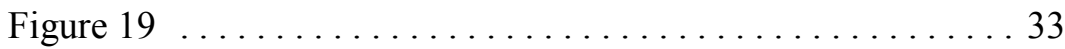

Figure 21. Gabion wall east of property shown in previous photographs, 17 May 1991 ............................. 34

Figure 22. Cottage with protective concrete blocks east of the location shown in previous figures, 17 May $1991 \ldots \ldots \ldots \ldots \ldots . \ldots 35$

Figure 23. Seawall made of concrete-filled tanks west of North East

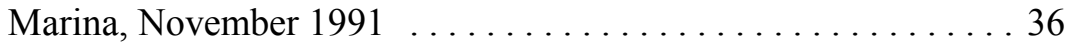

Figure 24. Bypassing at North East Marina . . . . . . . . . . . . . . . 39

Figure 25. West fillet sediment being loaded into dump trucks, 17 November 1998 . . . . . . . . . . . . . . . . . . . . . . . . . . . . 40 
Figure 26. Backhoe removing sand and gravel from updrift fillet, 17 November $1998 \ldots \ldots \ldots \ldots \ldots \ldots \ldots \ldots \ldots \ldots \ldots$

Figure 27. Temporary road along base and bluffs east of marina, 17 November $1998 \ldots \ldots \ldots \ldots \ldots \ldots \ldots \ldots \ldots \ldots \ldots \ldots . \ldots \ldots$

Figure 28. Sonograph immediately off marina wall, approximately halfway between east and west corners ............... 45

Figure 29. Sonograph, SW of the marina wall, shows additional bedrock jointing and bedding exposed on lake bed, with no evidence

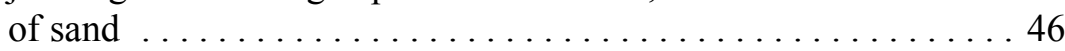

Figure 30. September 1999 profiles. State plane coordinate system, Pennsylvania North Zone, NAD 83, units in feet . . . . . . . . 49

Figure 31. Determination of volumetric difference between two profiles . . 52

Figure 32. Example of profile from sandy environment $\ldots \ldots \ldots \ldots \ldots$

Figure 33. Computation of sand volume for 5-30-90 preproject profile

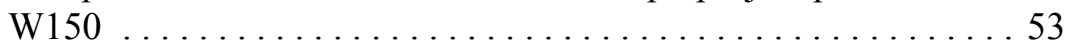

Figure 34. Extension of 5-30-90 from original shale line to location of shale line on $9-24-99$ profile $\ldots \ldots \ldots \ldots \ldots \ldots \ldots \ldots$

Figure 35. Volume measurement for $\mathrm{W} 150$ profiles . . . . . . . . . 55

Figure 36. Profile volume for lines W025 to W600 west of marina west

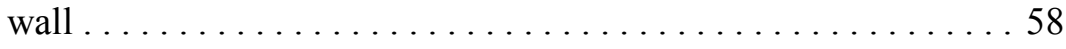

Figure 37. Profile volumes east of marina $\ldots \ldots \ldots \ldots \ldots \ldots \ldots \ldots$

Figure 38. Total volume for west and east beaches $\ldots \ldots \ldots \ldots \ldots$

Figure 39. Flow chart of mitigation alternatives $\ldots \ldots \ldots \ldots 6$

\section{List of Tables}

Table 1. Bluff Composition, Erie to North East, PA .......... 12

Table 2. $\quad 32-$ Year Hindcast Wave Statistics for WIS Station E21 . . . . . 14

Table 3. Recession Rate Statistics for 1-km Reaches, Lake Erie, PA . . . 25

Table 4. Annual Volume Bypassed by PFBC at North East Marina ... . . 40 
Table 5. Side-scan Sonar Specifications, 22 September 1999 Field

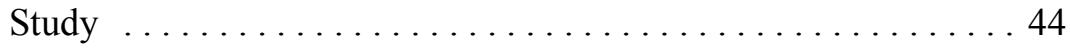

Table $6 . \quad$ Summary of VisualObservations $\ldots \ldots \ldots \ldots \ldots \ldots$

Table 7. Profile Volumes ......................... 56

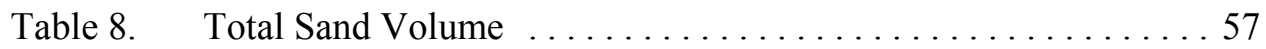

Table 9. Alternative Engineering and Management Solutions,

North East Marina . . . . . . . . . . . . . . . . . . 64 


\section{Preface}

The investigation summarized in this report was conducted by the U.S. Army Engineer Research and Development Center, Waterways Experiment Station (WES), Coastal and Hydraulics Laboratory (CHL). Work was performed under the general supervision of Ms. Joan Pope, Chief, Coastal Evaluation and Design Branch (CEERD-HC-S) and Mr. Thomas W. Richardson, Acting Director, CHL.

This report was written by Drs. Andrew Morang and Jeffrey Melton. The earlier Phase I report was reviewed by Dr. Jack Davis and Ms. Joan Pope (all of CEERD-HC-S), Mr. Thomas Bender (U.S. Army Engineer District (USAED), Buffalo) and Mr. Don Guy (Ohio Geological Survey).

This project was sponsored by U.S. Army Engineer District, Pittsburgh. Project managers at the Pittsburgh District were Messrs. James Cianciosi and Albert Rogalla.

Field data at the study site were collected by the following organizations/ contractors: topographic data, GRW Aerial Surveys, Inc. (Mr. Edward Rinehart); dive and video observations, the Buffalo District (Mr. Thomas Bender); sidescan sonar, Ohio Geological Survey (Dr. Scudder Mackey and Mr. Dale Liebenthal); aerial photographs, various contractors, coordinated by the Buffalo District (Mr. Thomas Bender).

The following representatives of the Pennsylvania Fish \& Boat Commission provided valuable field support and supplied historical charts and data:

Messrs. Gary Moore, Richard Mulfinger, and James Young.

Photographs and data were also supplied by the Buffalo District: Messrs. Thomas Bender, Richard Gorecki,, Richard Griffith, and Michael Mohr.

A detailed report prepared by Taylor and Buyce (1994) and discussions with Professor Buyce (Mercyhurst College, Erie, PA) provided much useful information. 
At time of publication of this report, Dr. James R. Houston was Director of ERDC, and Mr. Armando J. Roberto, Jr., was Commander.

The contents of this report are not to be used for advertising, publication, or promotional purposes. Citation of trade names does not constitute an official endorsement or approval of the use of such commercial products. 


\section{Introduction}

\section{Background}

In the mid- to late-1980s, a private developer planned a recreational boating facility on the shore of Lake Erie in North East Township, Erie County, in the northwestern corner of Pennsylvania. The facility was to have lake access with boat ramps, recreation sites, a marina with boat storage, and an administration building. In May 1990, permits for the construction of the facility, hereafter referred to as the North East Marina, were approved and endorsed by the U.S. Army Engineer District, Buffalo, and the Pennsylvania Fish and Boat Commission (PFBC), formerly the Pennsylvania Fish Commission.

The marina consists of an L-shaped concrete breakwater extending northwest from the shoreline about $150 \mathrm{~m}$. The breakwater then curves eastward paralleling the shore about $200 \mathrm{~m}$. An entrance to the marina is located at the eastern end of the breakwater. A second breakwater then continues back southeast toward shore about $150 \mathrm{~m}$. The exterior of the breakwater is protected with a stone riprap.

Following the completion of North East Marina in 1991, the original developer was unable to comply with the terms of the permit after a number of attempts to bypass sediment by truck and by using a hydraulic jet pump. After declaring bankruptcy, he transferred the marina and the operating permit to the PFBC in September 1993.

During the early years of operation, a dispute arose between several homeowners on the downdrift (east) side of the project and the operators of the marina regarding interruption of littorally-transported sediment. The homeowners challenged the PFBC's compliance with the conditions of the permit, and maintained that the U.S. Army Corps of Engineers abused its discretion by not enforcing the terms of the permit. In an effort to avoid protracted litigation, the U.S. District Court for the Western District of Pennsylvania issued an order confirming a stipulation between the parties. Excerpts of the agreement are as follows:

1. The Fish Commission will replenish not less than four thousand $(4,000)$ cubic yards of material from the west side of the North East Marina to the east side for the purposes of protecting the beaches east of 
the marina from the western property line of Edward Boll to at least fifty (50) yards past the eastern property line of Gerald Von Vreckin. The Parties specifically agree that it is their intent that sufficient material be moved so as to protect the aforementioned properties to the east of the Marina during the winter and early springs of 1998-1999. The Fish Commission shall insure that both the vertical and horizontal beaches are rebuilt. The Fish Commission shall begin moving material not later than November 9, 1998 and to complete the movement not later than December 15, 1998. The Fish Commission will move the same amount of material each spring and fall during their normal biannual movements until completion of the WES Study. Movements are contingent upon lake conditions.

2. The Corps of Engineers Waterways Experiment Station (WES) shall submit a study plan and/or a progress report for the restoration of the beaches east of the Marina to the Plaintiffs, the Fish Commission and the Corps of Engineers, Pittsburgh District, not later than March 31, 1999 as long as funding is secured to contract with WES. ...

5. The Plan should include the structures, if any, to be used to stabilize the beaches, the quantity of material to be moved, the quality of material to be moved, the method of moving, the method of restoring the beaches, the method to fully replenish and maintain the beaches each year and such other information as WES shall deem relevant. ...

Hence, the purpose of the study outlined in this report is to satisfy the court order and stipulation of the Federal court, and comply with the Corps' permit conditions by identifying and investigating alternative solutions to the beach erosion problem. This investigation was conducted by the U.S. Army Engineer Research and Development Center (ERDC), Coastal and Hydraulics Laboratory (CHL), under the sponsorship of the U.S. Army Engineer District, Pittsburgh, and the Pennsylvania Fish and Boat Commission. During the preparation of this report, the Pittsburgh District had permit authority for the Pennsylvania shore of Lake Erie.

\section{Study Objectives and Study Plan}

This study was designed to address the following issues:

a. Evaluate sediment processes in and near North East Marina.

b. Document historical behavior of the beaches near the marina to the extent possible given the available historical topographic data.

c. Evaluate several sediment management scenarios. 
d. Recommend an optimum sediment management process to maintain the natural flow of sediment along the shore in this vicinity.

This investigation has been divided into two phases, each subdivided into tasks. This report describes the results of both Phases 1 and 2 .

Phase 1 consisted of three tasks designed to determine and quantify the degree of beach accretion and erosion that are attributable to the marina. Task 1 consisted of data collection and preliminary analysis. Task 2 identified additional data to be acquired at the project site. Task 3 identified the impacts of the marina on the local sediment processes. The first task included acquiring and organizing historical data and photographs from the project site. Appendix A provides a chronological listing of events, historical and recent aerial photographs are reproduced in Appendix B, and all known cross-shore profiles are reproduced in Appendix C.

Phase 2 developed recommendations and alternative solutions for the project and outlined the advantages and disadvantages of each. This analysis also includes a discussion of actions that could restore the shoreline to conditions prior to the construction of the marina (if necessary), and a description of actions to prevent further damage to the existing shoreline. 


\section{Study Area and Physical Setting}

\section{Project Site}

North East Marina is located on the Pennsylvania shore of Lake Erie in North East Township, Erie County (Figures 1 and 2). The marina is immediately north of State Road 89, about $3 \mathrm{~km}$ east of the intersection of State Roads 5 and 89 and about $2 \mathrm{~km}$ from the New York state line. The countryside in this part of Pennsylvania consists of gently rolling hills and fields, largely planted with grapes. Private homes and summer cottages face the lake, and a number of former estates are used as schools or monasteries. The general shoreline azimuth along this reach of Lake Erie, from Erie to the New York state line, is $70 \mathrm{deg}$ (Figures 3, 4, and 5). The marina provides the only safe harbor of refuge between Erie, PA, and Barcelona, NY, a distance of $48 \mathrm{~km}$.

The marina is situated in a shallow $1,600 \mathrm{~m}$-long $(5,300 \mathrm{ft})$ embayment (Figure 6). The west end of the embayment is a headland that appears to be bedrock-controlled. The headland is triangular-shaped, and shale outcrops and loose boulders can be seen immediately offshore. A minor stream, known as Peck Run, emerges at the headland. The stream carries minimal sediment load because the bed is rocky and there is little sand at the mouth. The headland to the east appears to consist of sand deposited by Twentymile Creek. The terrain drained by these creeks is mostly used for grape cultivation. These fields are not plowed annually, and the land is carefully drained to minimize erosion. Therefore, in contrast to farms planted with more traditional crops, there is much less soil runoff. Twentymile Creek does appear to carry some sediment because the bar at the mouth changes size and shape over time (see photographs in Appendix B). Also, the side-scan sonar surveys imaged a broad sand accumulation in 6-8 $\mathrm{m}$ water depth off the headland.

Near the marina, the bluffs are about 5-8 $\mathrm{m}$ high (above the water level), with a crest elevation about 175-183 m (580-600 ft) International Great Lakes Datum 1985 (IGLD85). Lake Erie low water (chart) datum is $173.5 \mathrm{~m} \mathrm{(569.2} \mathrm{ft)}$ IGLD 85. 


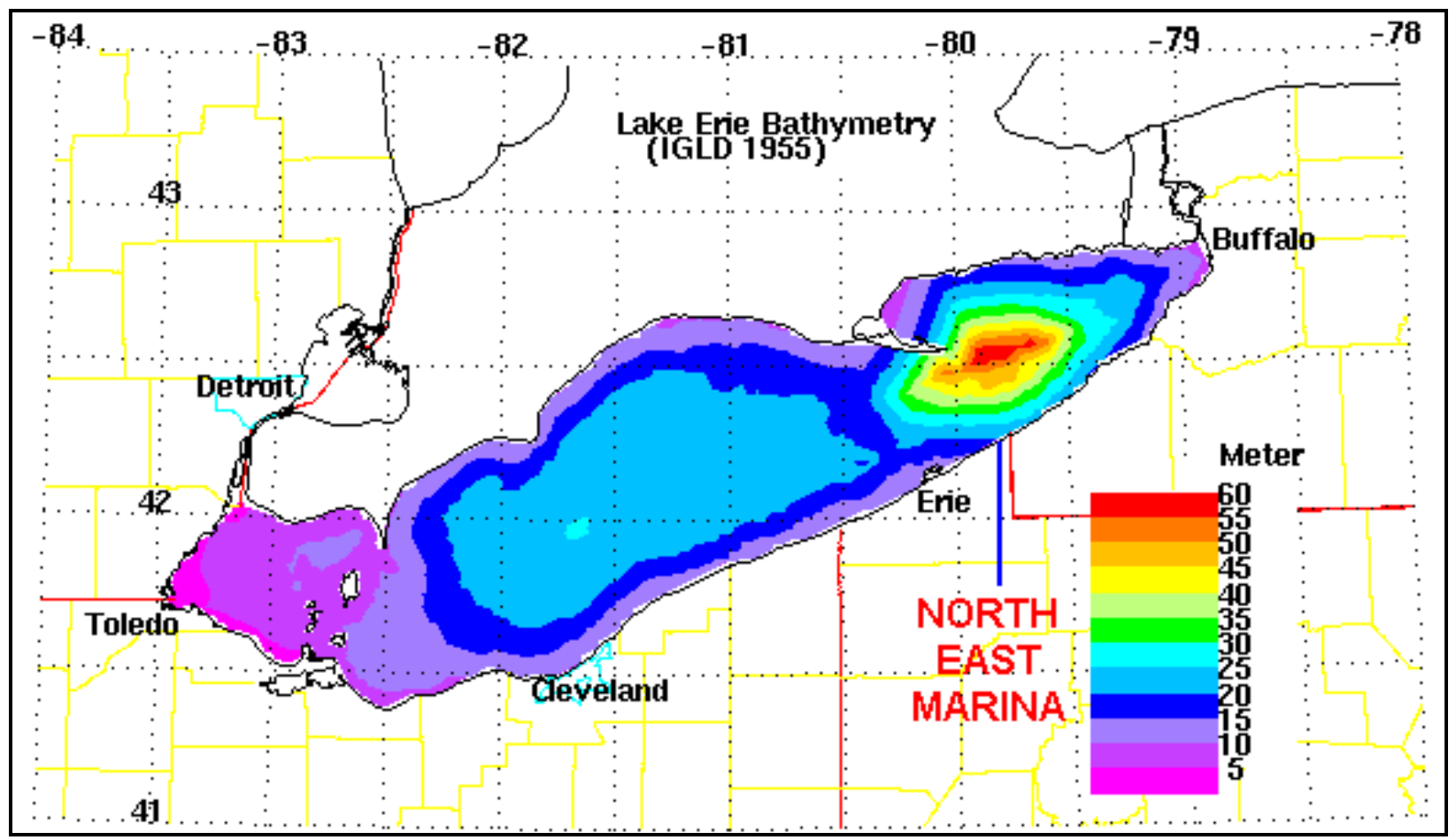

Figure 1. Study area, Lake Erie. North East Marina is east of city of Erie, near New York Pennsylvania border. Lake Erie contains three basins, with the study site facing deepest, eastern basin (map from U.S. Geological Survey)

At the shoreline next to the marina, the interface between rock and glacial deposits is about $0.5-1.0 \mathrm{~m}$ below the November 2000 water level of $174 \mathrm{~m}$. The shale extends offshore as a series of flat-topped shale terraces, which can be seen in aerial photographs (Figure 7). The surface of the shale undulates along the shore. The marina was built on a high portion, and the bedrock surface drops off about $0.5 \mathrm{~m}$ at a distance of $150 \mathrm{~m}$ to the east and west. The bedrock surface rises again about $300 \mathrm{~m}$ west, where exposed slabs can be seen on the beach and immediately offshore. The next high portion occurs another $300 \mathrm{~m}$ west, at the headland.

East of the marina, some of the shore is armored with various forms of structures installed by homeowners, including vertical concrete or steel seawalls, gabions, and rock or concrete rubble. Some structures can be seen in the 1974 aerial photographs, indicating that erosion has been a continuing problem in this area for many years.

Four interacting factors are largely responsible for the morphology of the Lake Erie coast and for the presence (or absence) of sediment on the shore. These factors are as follows: 


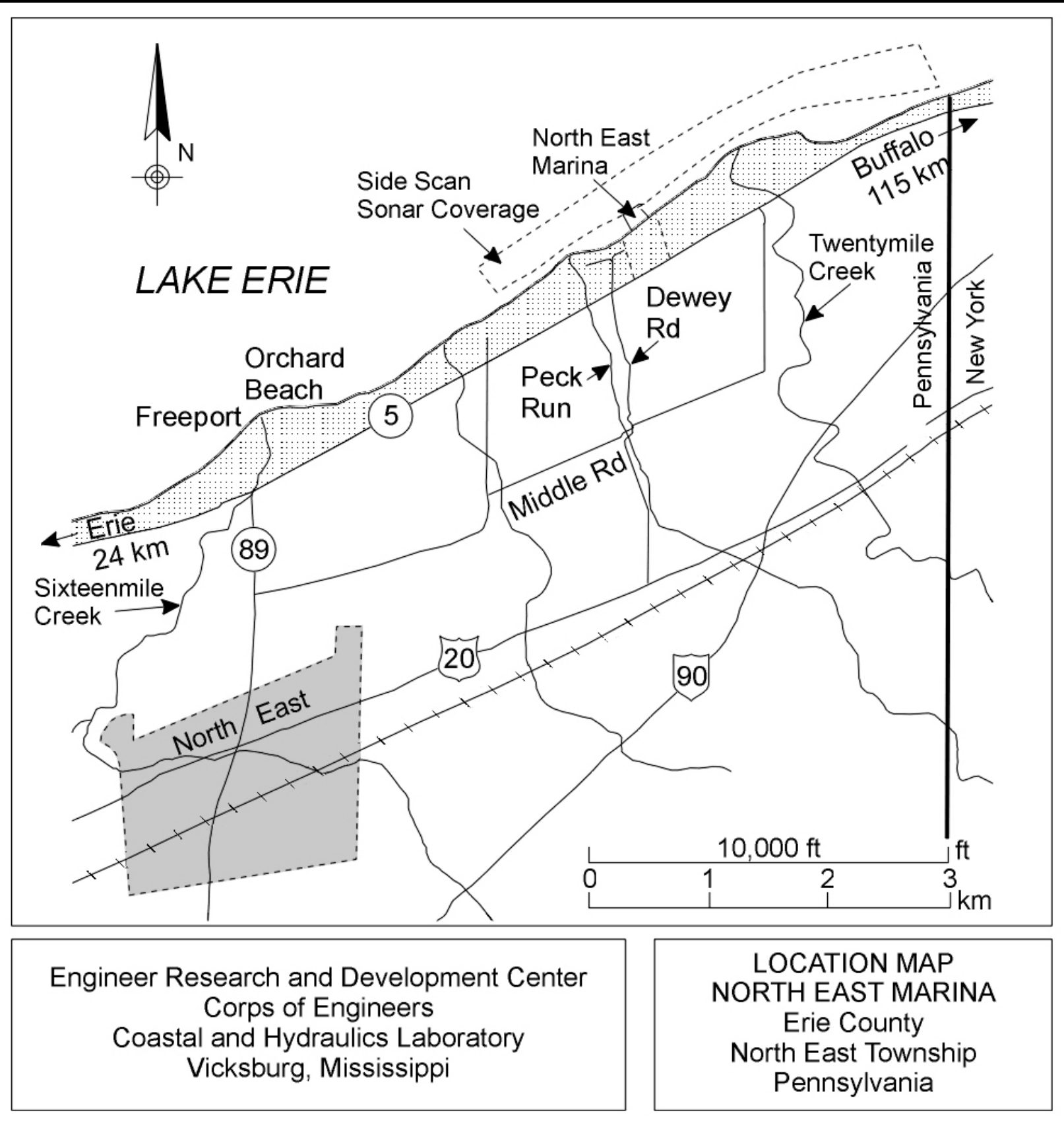

Figure 2. Physical features of North East Marina study site and surrounding area
a. Bedrock and glacial deposits.
b. Wave climate.
c. Lake level. 


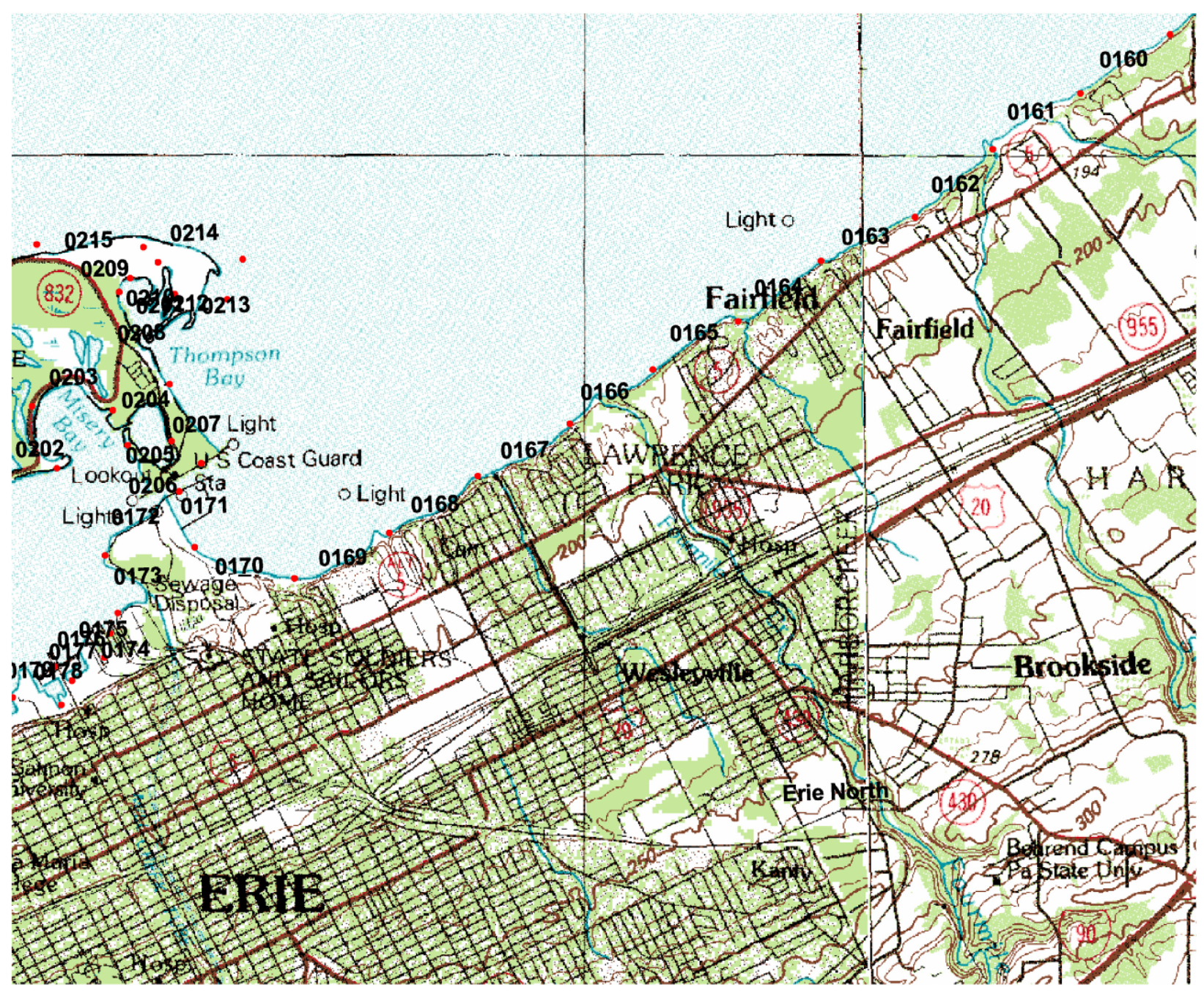

Figure 3. Topographic map of Lake Erie shore west of the study area, near Erie, PA. Small numbers along shore show 1-km reaches used for Lower Great Lakes Erosion Study. Maps courtesy of U.S. Army Engineer District, Detroit

d. Bluff erosion and sediment supply.

e. Manmade structures (usually built in response to these conditions).

\section{Bedrock and Glacial Deposits}

Most of the Pennsylvania shore of Lake Erie consists of low glacial bluffs, usually less than $10 \mathrm{~m}$ high, that lie above shale and siltstone bedrock. The elevation of the bedrock/till interface is one of the important factors that shapes and molds the morphology of the Pennsylvania shore. Typically, where the interface is above the water level, the lake reaches right up to near-vertical bluffs that are devoid of beaches. Occasional catastrophic failures do occur when large blocks of the bluffs collapse, but for the most part, these exposed bedrock 


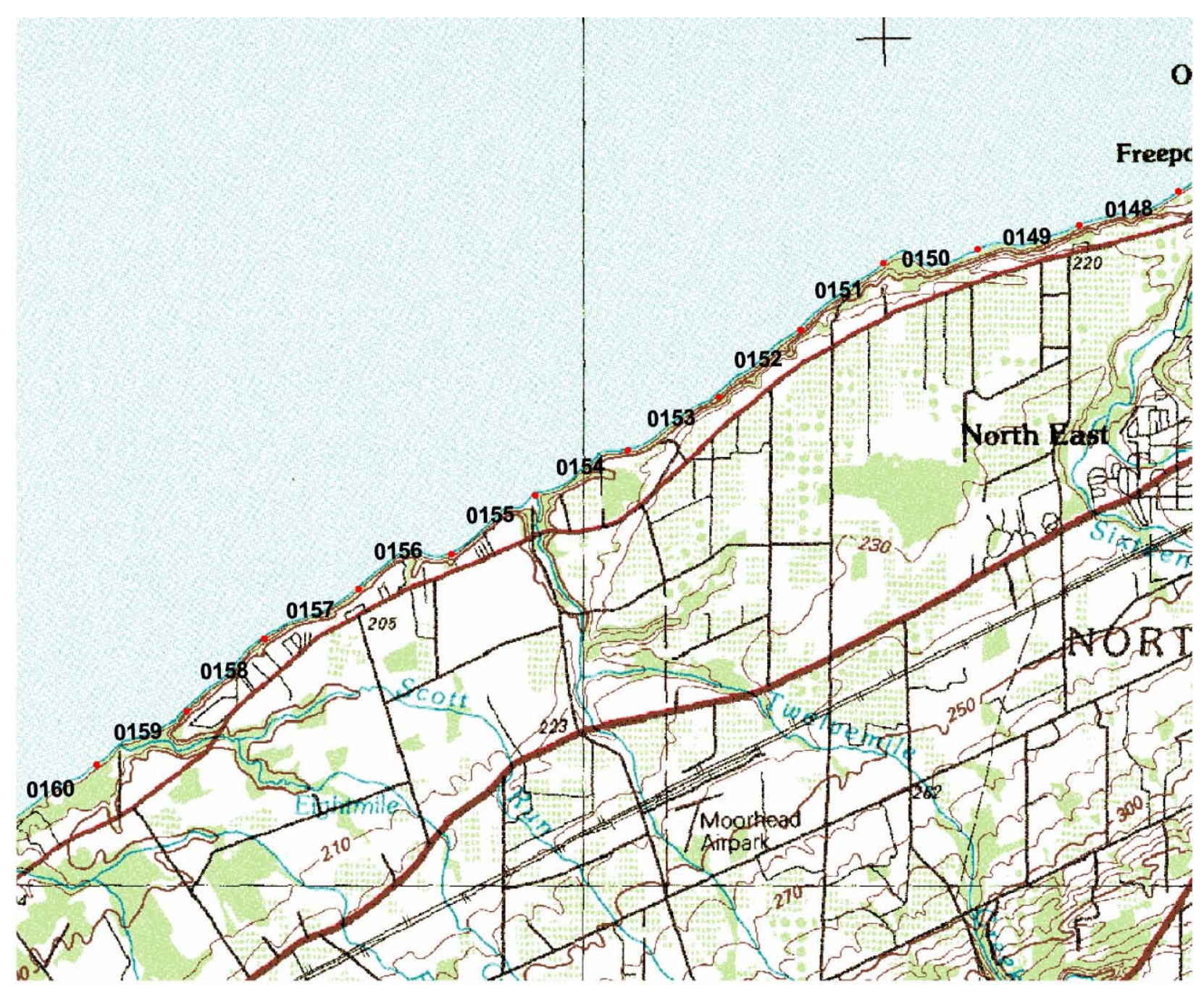

Figure 4. Topographic map of Lake Erie shore west of North East, PA, with 1-km reaches used for shoreline erosion statistics

sections resist erosion. An example of the resistant bluffs can be seen $3 \mathrm{~km}$ west of the project site, at Sixteenmile Creek, where the shale rises to about $3 \mathrm{~m}$ above the water level. At the mouth of Sixteenmile Creek, enough sand has accumulated to be used for a public bathing beach, but only $200 \mathrm{~m}$ east or west, the beach disappears and the lake reaches the bluff.

In contrast, at areas where the interface is at or below the water level, the bluffs are composed of much more vulnerable unconsolidated glacial till, and a sand/gravel beach often exists at the base of the bluff. These beaches are formed from both locally-derived sediment and material moved alongshore in the littoral drift. The fact that material does move from west to east along the Pennsylvania shore over great distances is verified by irregular-shaped rubber blocks with characteristic protrusions that can be seen at North East Marina and further east. The rubber came from a landfill at Erie, PA, that collapsed, dumping debris into Lake Erie. Within a few years, the rubber blocks had moved east over $30 \mathrm{~km}$. 


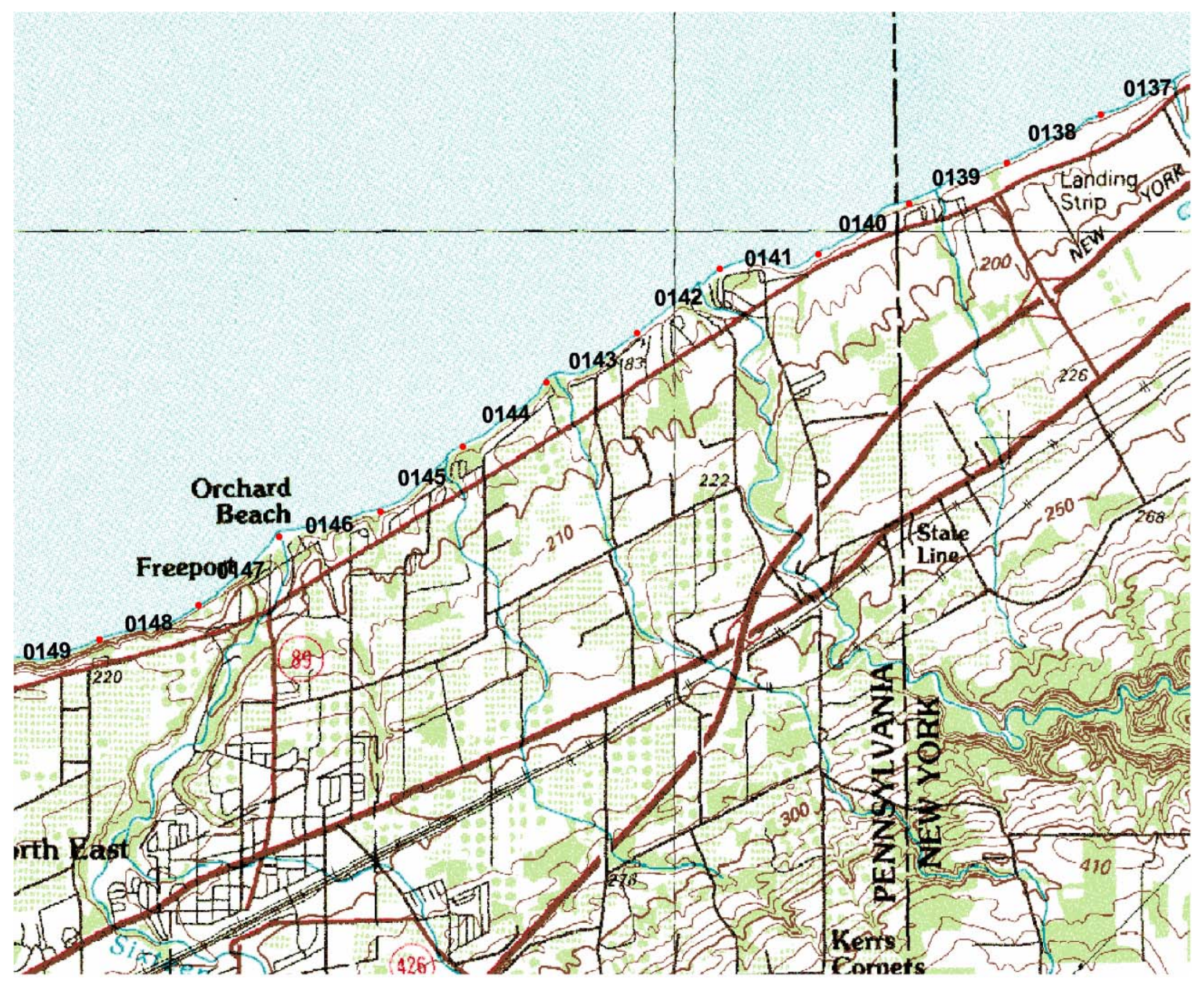

Figure 5. Lake Erie shore. Reaches 141, 142, and 143 span the North East Marina study area

Geier and Calkin (1983) concluded that the most important single control of erosion rates along unprotected stretches of the New York shore was the composition of the material in the bluffs and the height of the bedrock. The areas where the bedrock extended four or more meters above lake level had statistically lower erosion rates than the areas where till bluffs were accessible to storm wave attack.

The bedrock consists of interbedded layers of siltstone and shale belonging to the Upper Devonian North East Shale (Taylor and Buyce 1994). The bedrock layers dip about $5 \mathrm{deg}$ to the southwest and are fractured by irregular joints. Because of the joints, offshore bedrock exposures resemble a series of flat terraces with irregular edges. Joints within the flat units are enlarged over time as they fill with cobbles and boulders that serve as an abrasive agent. Aprons of debris, eroded from the crumbling edges of the terraces, are seen at the base of many of the steps. 


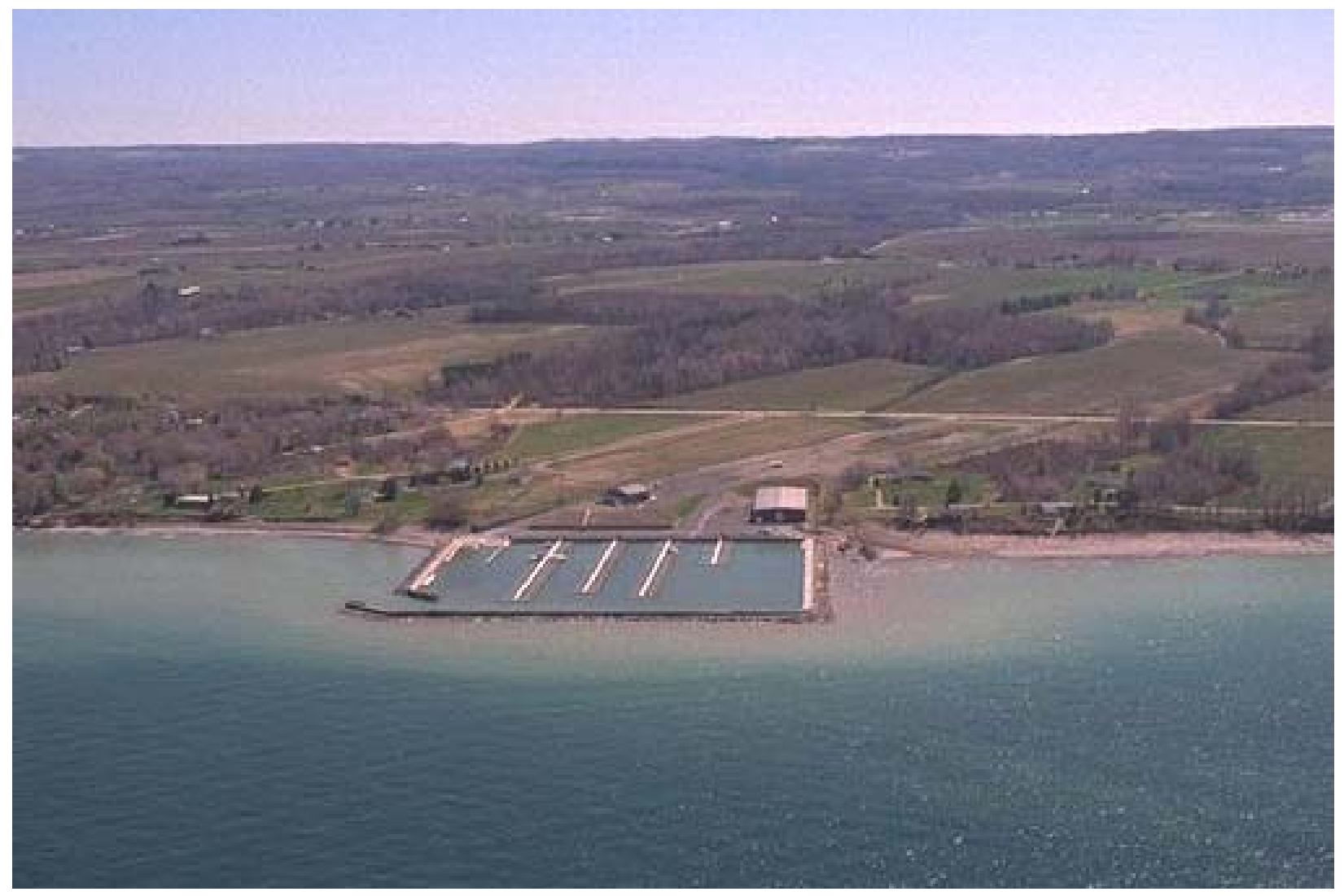

Figure 6. Oblique aerial photograph of marina looking southeast, April 1999. PFBC's spring bypassing operation is in progress, and a backhoe and truck are in the fillet on the right side of the marina. Photograph courtesy Buffalo District

Bedrock on the beach and in the shallow nearshore are a source of cobbles and coarse gravel beach sediment. During storms or possibly during ice movement, pieces of shale break off from the edges of the terraces. Some of these loose chunks move onto the beach, becoming part of the coarse cobble that is often found along the shore. Over time, the angular blocks of shale are broken down into smaller and smaller pieces, eventually becoming sand-sized. Examination of beach sand near North East Marina using a hand-held magnifier revealed that the sediment has been sorted alongshore. The brown, fine-grain sand on the beach west of the west wall was mostly well-rounded quartz with various dark minerals. But, the sand at the mouth of Twentymile Creek was gray and much coarser, consisting of about 50 percent shale fragments.

Pleistocene glacial deposits overlie the Devonian shale and siltstone. These deposits include unconsolidated tills composed of cobble in a matrix of sand, silt, and clay, overlaid by lacustrine sands (Taylor and Buyce 1994). Often the lower portions of the till contain large stones from the local bedrock, up to 80 percent by volume (Geier and Calkin 1983). The till bluffs vary greatly in composition along the shore between Erie and the New York state line and are highly susceptible to wave erosion compared to the bedrock. In 1985, the Buffalo District collected a series of samples from the bluffs and conducted 


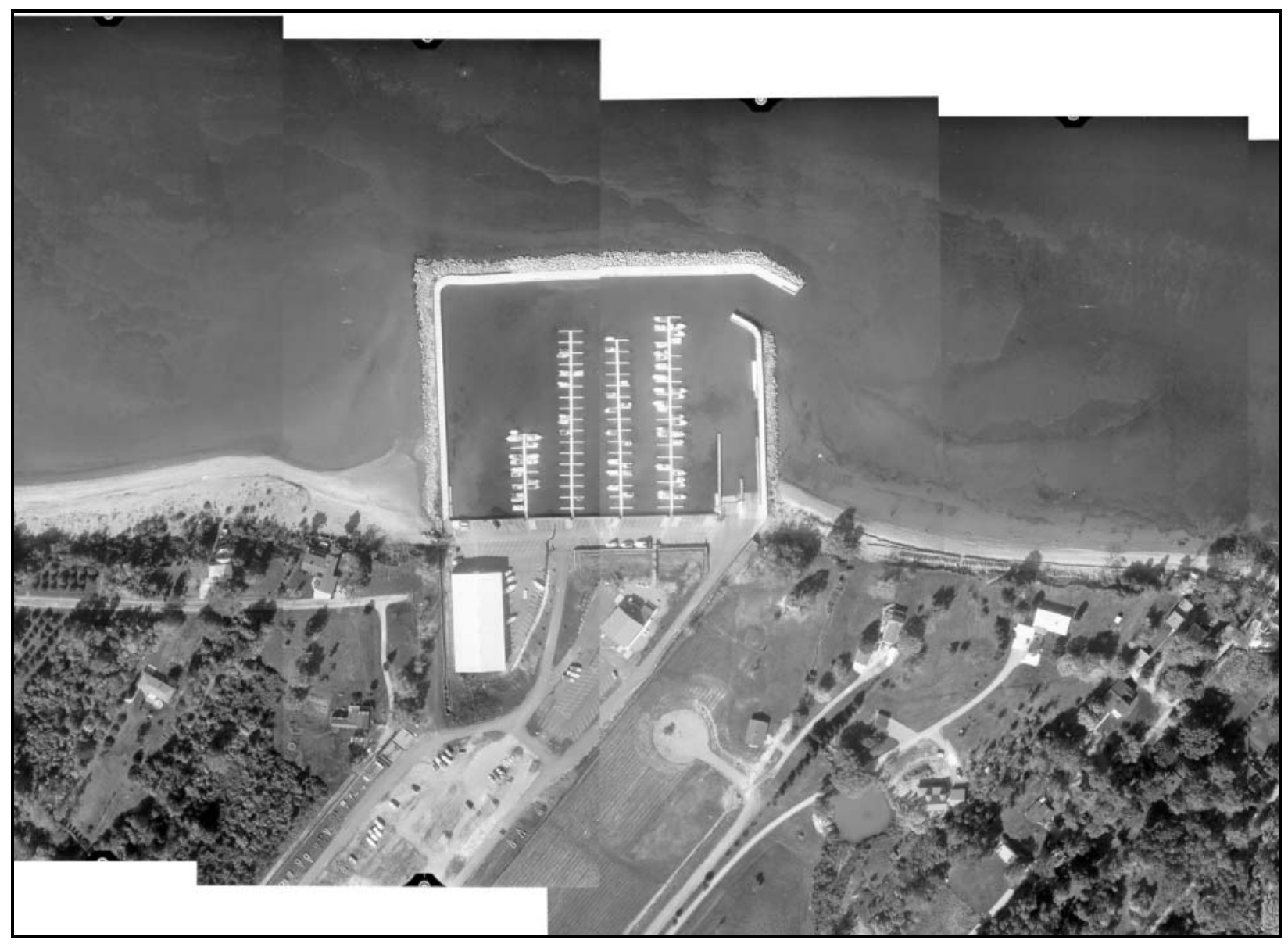

Figure 7. Vertical aerial photograph, October 15, 1999. Shale ledges can be seen through water east (to the right) and lakeward of marina. Bulge in shore west (left) of the marina is accretion on private property that PFBC is unable to mine during biannual bypassing operations

geotechnical tests (summarized in Table 1). The clastic (sand and gravel) content of the till bluffs ranges from 11 to 67 percent. Similar samples collected by Geier and Calkin (1983) in New York State found that the sand and gravel content of the bluffs ranged from zero to 39 percent.

The till bluffs along much of the Lake Erie shoreline have been eroding since the Pleistocene glaciers receded and the present lake was formed. Erosion is caused by a combination of factors:

a. Wave attack at the base of the till bluffs during storms. Storm waves can break directly at the toe of the bluffs, causing erosion and undercutting. The till is either washed away in situ or large blocks of the bluff fail and slump down onto the beach, where the material is broken up by waves.

The frequency at which bluffs may be subject to direct wave attack is a function of water level and sand supply (i.e., beach width). 


\begin{tabular}{|c|c|c|c|c|c|}
\hline \multicolumn{6}{|c|}{$\begin{array}{l}\text { Table } 1 \\
\text { Bluff Composition, Erie to North East, PA }\end{array}$} \\
\hline Sample & Location & $\begin{array}{l}\text { Amt. of bluff } \\
\text { similar to sample } \\
\text { (height, } \mathrm{m} \text { ) }\end{array}$ & $\begin{array}{l}\text { Description and } \\
\text { classification }\end{array}$ & $\begin{array}{l}\text { Percent } \\
\text { sand }\end{array}$ & $\begin{array}{l}\text { Percent } \\
\text { gravel }\end{array}$ \\
\hline 1 & $\begin{array}{l}\text { Lakeside cemetery, } \\
\text { Erie }\end{array}$ & 14 & Sandy clay (CL) & 22 & 7 \\
\hline 2 & Franklin Ave., Erie & 9 & $\begin{array}{l}\text { Weathered shale, } \\
\text { brownish gray }\end{array}$ & none & none \\
\hline 3 & Lawrence Park & 3 & $\begin{array}{l}\text { Sandy clayey gravel } \\
\text { (GC) }\end{array}$ & 22 & 52 \\
\hline $4 \mathrm{~A}$ & \multirow[t]{3}{*}{ Fairfield } & \multirow[t]{3}{*}{8} & Gravelly silty sand (SM) & 36 & 30 \\
\hline $4 \mathrm{~B}$ & & & Clay (CL) & 11 & 1 \\
\hline $4 C$ & & & Clay (CL) & 10 & 1 \\
\hline 5 & $\begin{array}{l}\text { Just west of Sixmile } \\
\text { Creek }\end{array}$ & 9 & $\begin{array}{l}\text { Clayey sandy gravel } \\
\text { (GC) }\end{array}$ & 24 & 61 \\
\hline $6 \mathrm{~A}$ & \multirow{3}{*}{$\begin{array}{l}\text { Just west of } \\
\text { Eightmile Creek, } \\
\text { near town of } \\
\text { Harborcreek }\end{array}$} & \multirow[t]{3}{*}{7} & $\begin{array}{l}\text { Gravelly sandy clay } \\
\text { (SC) }\end{array}$ & 32 & 27 \\
\hline $6 B$ & & & Sandy silt (ML) & 25 & 6 \\
\hline $6 C$ & & & Sandy clay $(C L)$ & 35 & 12 \\
\hline 7 & $\begin{array}{l}\text { Near Highmyer } \\
\text { Road }\end{array}$ & 7 & Sandy silt (ML) & 26 & 5 \\
\hline $8 \mathrm{~A}$ & \multirow{2}{*}{$\begin{array}{l}\text { Just east of } \\
\text { Twelvemile Creek }\end{array}$} & \multirow[t]{2}{*}{7} & Sandy silt (ML) & 35 & 13 \\
\hline $8 B$ & & & $\begin{array}{l}\text { Gravelly clayey sand } \\
\text { (SC) }\end{array}$ & 37 & 15 \\
\hline $9 \mathrm{~A}$ & \multirow[t]{2}{*}{$\begin{array}{l}\text { Near Brickyard } \\
\text { Road, North East }\end{array}$} & \multirow[t]{2}{*}{7} & $\begin{array}{l}\text { Gravelly clayey sand } \\
\text { (SC) }\end{array}$ & 33 & 20 \\
\hline $9 \mathrm{~B}$ & & & Sandy clay (CL) & 18 & 7 \\
\hline $12 \mathrm{~A}$ & \multirow{2}{*}{$\begin{array}{l}1,500 \mathrm{~m} \text { east of } \\
\text { Sixteenmile Creek }\end{array}$} & \multirow[t]{2}{*}{1.5} & Sandy silty gravel (GM) & 32 & 35 \\
\hline $12 B$ & & & Sandy silty gravel (GM) & 38 & 44 \\
\hline
\end{tabular}

b. Geotechnical failures caused by groundwater freeze-thaw cycles and seepage. In locations where the shale is above the lake level, groundwater flows along the impermeable surface, forming a lubricated slip plane. When water flows between plates of shale, freezing causes expansion and cracking. The rate of shale erosion is much less than that of till or glaciolacustrine bluffs, but nevertheless does contribute sediment to the littoral system. Many Lake Erie beaches are covered with fractured plates of shale ranging from sand-size to cobble.

c. Downcutting by rivers where they flow into the lake. 
Ice coating on the bluffs can prevent free drainage of the groundwater, causing hydrostatic pressure to build up in the bluff, prompting slope failures.

In September, 1999, we observed a section of bluff failing on the second property east of the marina. It looked like rainwater ponded near the edge of the bluff and soaked into the ground, liquifying the till. Further east, another landowner had installed catch basins and drains to carry rainwater down to the base of the bluff. Starting about $240 \mathrm{~m}$ east of the marina, a variety of artificial structures have been constructed by homeowners to reduce mass wasting and to protect the bluffs from wave attack.

\section{Wave Climate}

Lake Erie has a wave environment characterized by long periods of calm interrupted by rapidly-developing, short-lived, high-energy storms. Great Lakes storm waves are typically shorter-period (less than $\approx 6 \mathrm{sec}$ ) and steeper than ocean storm waves. Also in contrast to ocean coasts, there are no long-period swell waves. Lake Erieís wave climate has a seasonal component. The highest energy storms usually occur in autumn, during October, November, and December, before the lake freezes, and in the spring (March and April), after the ice breaks up. During some winters, the lake does not freeze, and then the storm season lasts over six months. The summer months normally are characterized by moderate to low waves.

The strongest winds, associated with the passage of atmospheric lows, are from the southwest and west. Because this dominant wind direction corresponds to the long axis of the lake, wave energy flux is also a maximum from the southwest/west (Taylor and Buyce 1994). Therefore, the predominant sediment transport direction along the Pennsylvania shore is from west to east. However, at times the waves come from the north and northeast, causing some westwarddirected sediment movement, although the amount is minor compared to the eastward-directed transport. Figure B6, from April 1999, shows distinct wave crests from the north.

Wave statistics for Lake Erie have been hindcast by the Coastal and Hydraulics Laboratory based on historical wind fields as part of the Corps of Engineersí Wave Information Study (WIS) (Driver, Rinehard, and Hubertz 1991). The WIS station closest to North East Marina is sta 21 at $42.45^{\circ} \mathrm{N}$ and $79.77^{\circ}$ W. Table 2 lists summary statistics for the 32-year period from 1956 to 1987 for sta 21 . The most frequent wave direction was from the west/southwest $(247.5 \infty)$ and mean peak period was only $4.2 \mathrm{sec}$. Hindcast wave statistics are not available for the 1990s.

During May and June of 1994, observers collected Littoral Environmental Observations (LEO) data at stations east and west of the marina (Taylor and Buyce 1994). Breaker heights were in the range of $0.3-0.8 \mathrm{~m}$, with periods of 2.2 to $4.8 \mathrm{sec}$. The observers noted that the character of the breakers was different east and west of the marina. To the west, where there was a flatter 


\begin{tabular}{|c|c|c|}
\hline \multicolumn{3}{|c|}{$\begin{array}{l}\text { Table } 2 \\
32-Y e a r \text { Hindcast Wave Statistics for WIS Station E21 }\left(42.45^{\circ} \mathrm{N} \text {, }\right. \\
\left.79.77^{\circ} \mathrm{W}\right)\end{array}$} \\
\hline Statistic & Value & Unit \\
\hline Mean significant wave height $\left(\mathrm{H}_{\mathrm{s}}\right)$ & 0.9 & $\mathrm{~m}$ \\
\hline Mean peak wave period $\left(T_{p}\right)$ & 4.2 & $\mathrm{sec}$ \\
\hline $\begin{array}{l}\text { Most frequent } 22.5 \text { deg (center) direction band (i.e., direction } \\
\text { from where waves are coming) }\end{array}$ & 247.5 & $\operatorname{deg}$ \\
\hline Standard deviation of wave $\mathrm{H}_{\mathrm{s}}$ & 0.7 & $\mathrm{~m}$ \\
\hline Standard deviation of wave $T_{p}$ & 1.3 & sec \\
\hline Largest wave $\mathrm{H}_{\mathrm{s}}$ & 5.9 & $\mathrm{~m}$ \\
\hline Wave $T_{p}$ associated with largest wave $H_{s}$ & 10.0 & sec \\
\hline Average direction associated with largest wave $H_{s}$ & 264.0 & $\operatorname{deg}$ \\
\hline Date of largest $\mathrm{H}_{\mathrm{s}}$ occurrence & \multicolumn{2}{|c|}{ 01-25-1972 05:18 } \\
\hline Period of record & \multicolumn{2}{|r|}{$1956-1987$} \\
\hline Input wind stations & \multicolumn{2}{|c|}{$\begin{array}{l}\text { Buffalo, Cleveland, Erie, } \\
\text { Toledo, Point Pelee, Simcoe }\end{array}$} \\
\hline $\begin{array}{l}\text { Source: Driver, Rinehard and Hubertz } 1991 \\
\text { For additional information on wave terminology and statistic } \\
\text { (1984) or Morang, Larson, and Gorman (1997a). }\end{array}$ & Chomo & Manual \\
\hline
\end{tabular}

offshore sand platform, the surf zone was 20-50 m wide and the waves were dissipative in character. The waves broke in deep water and propagated towards shore as spilling breakers, sometimes even reforming and breaking again close to shore. We observed this same phenomena during the September 1999 field study (Figure 8). Dissipative beaches are characterized by waves that break by spilling and dissipating progressively across a wide surf zone, finally becoming very small at the upper portion of the foreshore (Wright and Short 1984). The spilling breakers enhance the shoreward transport of sediment and the growth of the fillet. This process is seen at sandy ocean beaches, where the dissipative stage is analogous to the "storm" or "winter beach" profile. Storm beaches recover as waves move sand onshore during milder conditions.

In contrast, Taylor and Buyce (1994) recorded that the width of the surf zone east of the marina was typically less than 5-10 m. Because of the lack of an offshore sand platform, incident waves broke immediately adjacent to the beach in the form of plunging or surging breakers. Because the surf zone is narrow and wave energy is concentrated in a narrow band along the beach, this area is more reflective than the west beach. Here, the plunging or surging breakers enhance erosion and sediment transport along the shore. Sediment in the littoral drift typically remains in transit because too much energy is concentrated on the foreshore for much material to accumulate. In 1999, the east beach for the most part was still reflective except for a 100-m zone west of the mouth of Twentymile Creek, where a broad, fine sand beach has formed since 1998 (coinciding with the rapid fall in lake levels). 


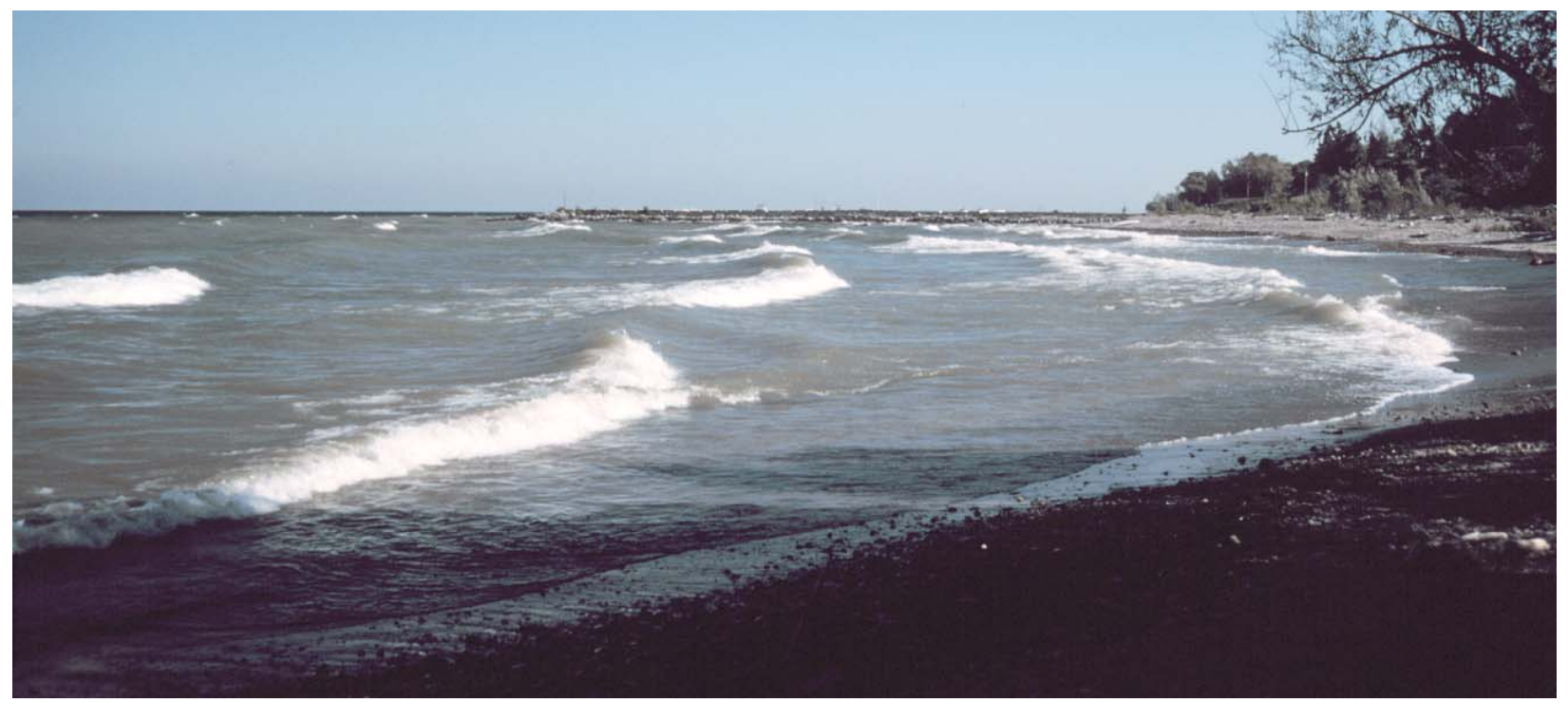

Figure 8. Spilling waves on west side of North East Marina, 22 September 1999. Surf zone was 20-40 m wide, and outer line of breakers formed approximately along a line extending from marina outer wall to west headland

Ice cover greatly affects wave energy reaching the shore. Lake Erie, the shallowest of the five Great Lakes, with a mean depth of $19 \mathrm{~m}$, can be divided into three basins: the shallow western basin located west of Point Pelee, the deeper central basin between Point Pelee and Long Point, and the deepest eastern basin east of Long Point (Figure 1). In addition to being the shallowest lake, Erie also has the least volume of the five Great Lakes. This combination of factors allows the temperature of the lake to respond quickly to changing atmospheric conditions. The first lasting ice usually develops on the lakes during the first week of December, and the ice season ends when the last observed or analyzed ice melts, usually around the beginning of May. The dates of starting and ending vary based on the severity of the ice year. During a "normal" Great Lakes winter, the ice cover on Erie exceeds 90 percent (Driver, Reinhard, and Hubertz 1991), but coverage can vary greatly from year to year. For example, the winter of 19971998 was essentially ice-free (International Niagara Working Committee 1999).

Ice cover can have several shoreline effects:

a. High percent coverage reduces the open water available for wave generation. Therefore, during a cold winter, wave energy is significantly reduced during the time when much of the lake is frozen.

b. Shore ice can protect the shoreline even if significant storm waves develop in open water further offshore (Figure 9) .

c. During the spring breakup of the shore ice, the beach and nearshore can be gouged by blocks of ice as they overturn and are pushed by waves or 


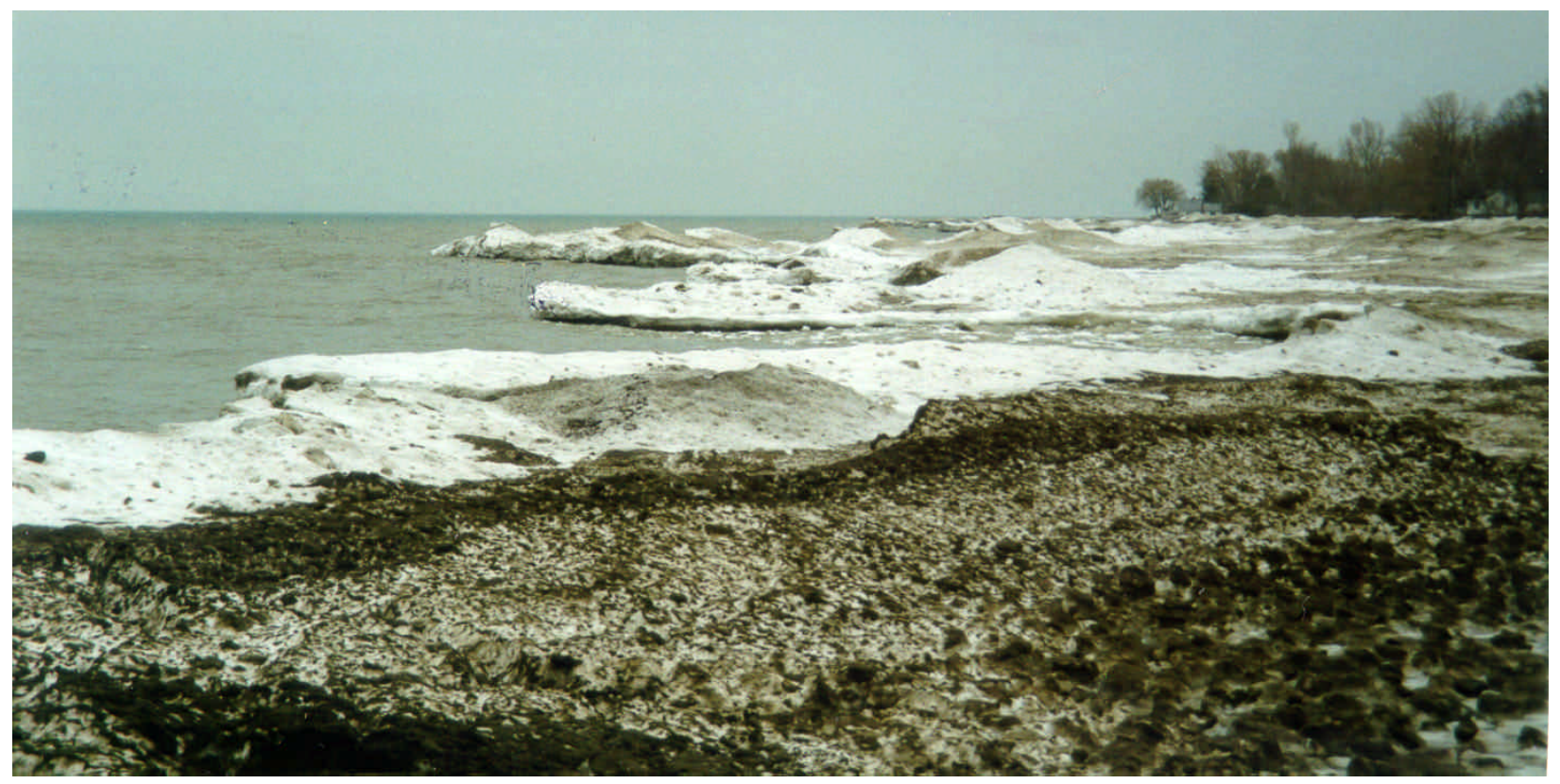

Figure 9. Ice armor along beach, 29 January 1999. During winter, ice protects shore from direct wave attack, but during spring thaw, ice blocks overturn, picking up masses of sand and gravel. View northeast towards Twentymile Creek. Photograph from Buffalo District archives

other ice blocks. Overturning ice blocks pick up sand and gravel cemented to their lower surfaces.

d. Ice blocks can damage shore structures and can move sediment.

We have insufficient data to quantify how ice cover affects sediment movement at North East. Water temperature, recorded daily at the Buffalo water intake, has been used to identify ice coverage conditions for the eastern basin of Lake Erie. The intake temperature data is used by New York Power Authority engineers to help plan the installation and removal of the Buffalo River ice boom (International Niagara Working Committee 1999).

The plotted monthly mean water temperatures show that the period that eastern Lake Erie is frozen, as indicated by a monthly average of $0^{\circ} \mathrm{C}$, varies from zero to four months (Figure 10). During most winters, at least one month is frozen, but 1993-1994 and 1995-1996 were unusually cold, with four frozen months each. During 1997-1998, the lake was ice free. Other ice-free or limited-ice winters this century have included 1952-1953, 1973-1975, 19821983, 1987-88, and 1991-1992 (International Niagara Working Committee 1999). These are the same years that the El Niño/Southern Oscillation phenomena caused major changes in water temperature and currents in the Pacific Ocean. ${ }^{1}$

${ }^{1}$ El Niño and La Niña episodes compiled by the Climate Prediction Center (NOAA): http://www.cpc.ncep.noaa.gov/products/analysis_monitoring/ensostuff/ensoyears.html (14 February 2000). 


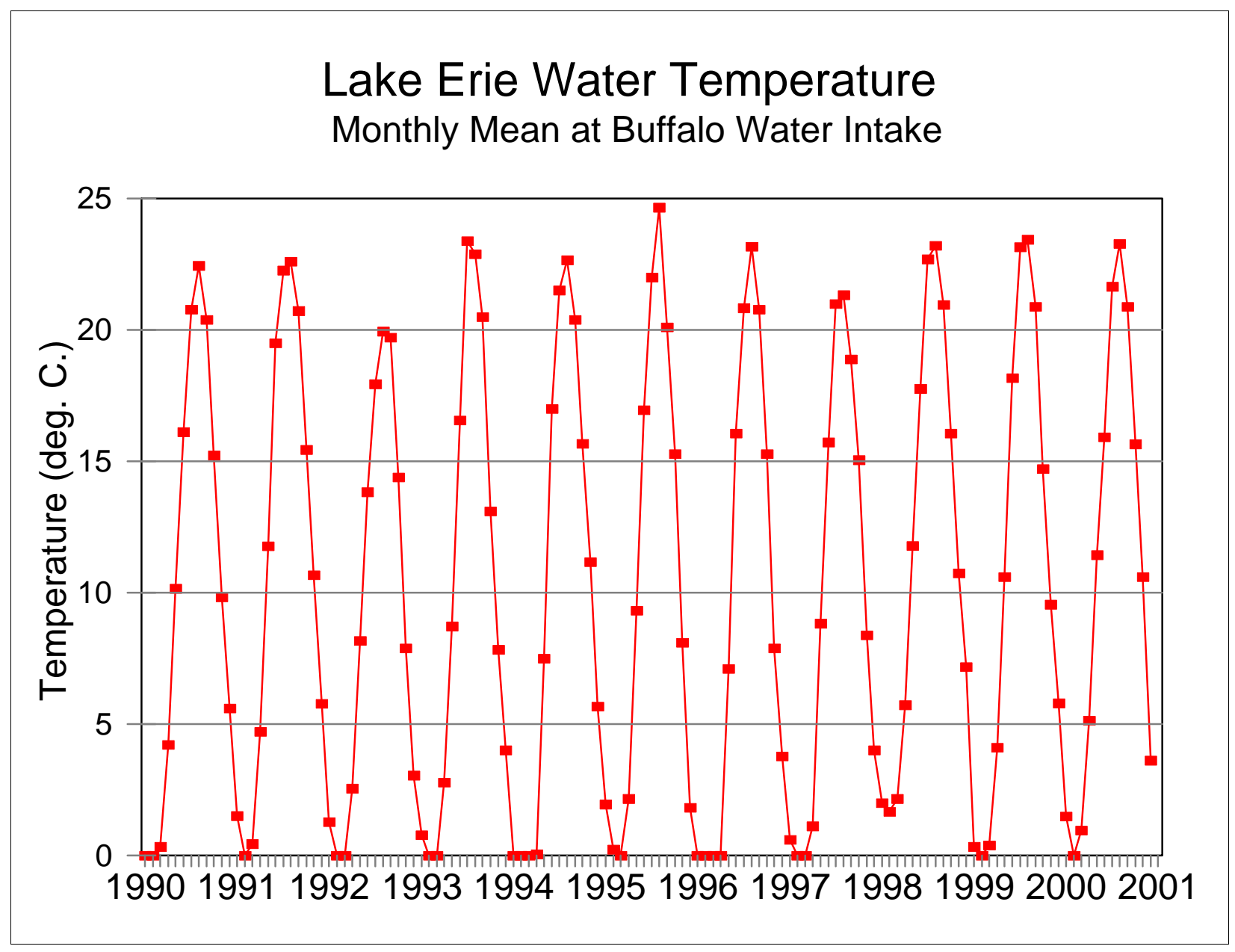

Figure 10. Mean monthly water temperature, averaged from daily readings at the Buffalo, NY, water intake. Note that the winter of 1997-1998 was ice-free (water temperature never reached $\left.0^{\circ} \mathrm{C}\right)$. Data provided by Buffalo District

The only ice-free winter since the marina was built was 1997-1998. This was also a winter of exceptionally high lake level. During 1998, PFBC bypassed the greatest annual amount of material of its 7-year management of the marina, some $24,000 \mathrm{yd}^{3}$. Whether this unusually large amount of sediment can be directly attributed to high-water level and an ice-free winter is impossible to prove, but it does appear as if a greater than normal amount of sediment moved along the coast that year and was thus available for bypassing.

Global climate patterns also influenced storminess on the Great Lakes during 1998:

Weather events across the Great Lakes in 1998 were remarkable compared to "average" years leading into the mid-1990s, with the most outstanding feature being the increased strength of storms in the area. Possibly as a direct result of El Niño-related warm conditions this past winter and spring, the atmosphere has become more volatile, especially over the past 
year. The Great Lakes experienced storms packing more wind, which created rarely seen storm rise heights on the lakes. This is illustrated by the 11-ft difference in water levels between Toledo, Ohio and Buffalo, New York that occurred on November 10, 1998. The hurricane-force winds (gusting to $94 \mathrm{mph}$ at Mackinac Island on November 10th) was the worst storm to hit the Great Lakes in 5 years and was similar in strength and path to the "Winds of November" storm of 1975 that claimed the Edmund Fitzgerald. ${ }^{1}$

\section{Lake Level}

The Great Lakes of the United States have always been subject to water-level changes that occur over irregular intervals. Five main factors are responsible, which include the following:

a. Long-term geologic changes on scales of centuries, such as crustal movements. For example, the earth's crust at the eastern end of Lake Superior is rebounding about $25 \mathrm{~cm} /$ century faster than the western end, resulting in a drop of the datums (apparent higher water) at the west end at Duluth.

b. Global climate trends over periods of decades to centuries. Long-term changes are caused by regional hydrographic conditions such as precipitation, runoff, temperature and evapo-transpiration, snow melt, and ice cover (Great Lakes Commission 1986).

c. Seasonal changes in rainfall, ice cover, and evaporation.

d. Storms and seiches. On the Great Lakes, astronomic tides have little influence on water levels. Instead, atmospheric pressure changes and winds cause most of the short-term fluctuations.

e. Manmade changes to the basins and watersheds due to navigation structures, shore and river modifications, and land use.

Aquatic plant life may also influence the exceedingly complex cycles of waterlevel changes in the Great Lakes. As a result, the concept of mean water level is not applicable to these inland Great Lakes unless it refers to a particular period, such as the mean level during a specified month or week.

\footnotetext{
${ }^{1}$ Summary of wave and water level conditions from Detroit District Web page: http://huron.lre.usace.army.mil/levels/summary/update98.html (16 Apr 2001).
} 
The following text from the Detroit District provides additional information on short-term water-level fluctuations: ${ }^{1}$

Short-term fluctuations are due to storms, wind or ice jams and usually last from a couple hours to several days. Ice jams will decrease the amount of water flowing out of a lake, which will temporarily increase its level until it is cleared. For example, ice jams have occurred in the St. Clair River delta, causing an increase in water levels upstream of the blockage and reduction in the inflow to Lake St. Clair. During this winter (1999-2000), ice conditions in this area were significantly less than normal.

Sustained high winds also can cause short-term fluctuations. High winds, especially strong from one direction, can push the water level up at one end of the lake and make the level drop by a corresponding amount at the opposite end. This is called wind setup. When the winds cease, the water will eventually return to its original position.

Seasonal fluctuations in water levels also occur throughout the Great Lakes. The Great Lakes are generally at their lowest levels in the winter months. Though the precipitation is fairly constant throughout the year, the winter snow pack does not contribute to lake level rise until the spring thaw and corresponding runoff. The combination of snow melting and rain in the spring contribute to the increase in lake levels from around March through August, depending on the lake. Evaporation is the greatest in the fall and early winter when the air above the lakes is cold and dry and the lakes are relatively warm.

Long-term fluctuations occur over a period of years and depend on how wet or dry and hot or cold the weather is. The Great Lakes system experienced extremely low levels in the late 1920s, mid-1930s and in the mid-1960s. Extremely high-water levels were experienced in the early 1950s, early 1970s, mid-1980s and mid-1990s.

During the last century and a half, Lake Erieís water level has ranged between 173 and 175 m IGLD 1985 (Figure 11). Research by Thompson and Baedke (2000) indicates that this 150 years of recorded lake levels captured most, if not all, possible lake-level extremes not associated with glacial times. Lake level was generally low during the early decades of the $20^{\text {th }}$ century, with the lowest stage of 173.4 m occurring during the dust bowl years of the Great Depression (19331935). Levels rose during the 1940s and dropped again in the 1950s, culminating in a minimum of about $173.6 \mathrm{~m}$ during the drought of 1964-1965. Thereafter, lake levels rose steadily for 10 years and then remained high for three decades.

\footnotetext{
${ }^{1}$ From Detroit District Web page:

http://huron.lre.usace.army.mil/levels/summary/1999lwl.html (30 Jan 2000).
} 


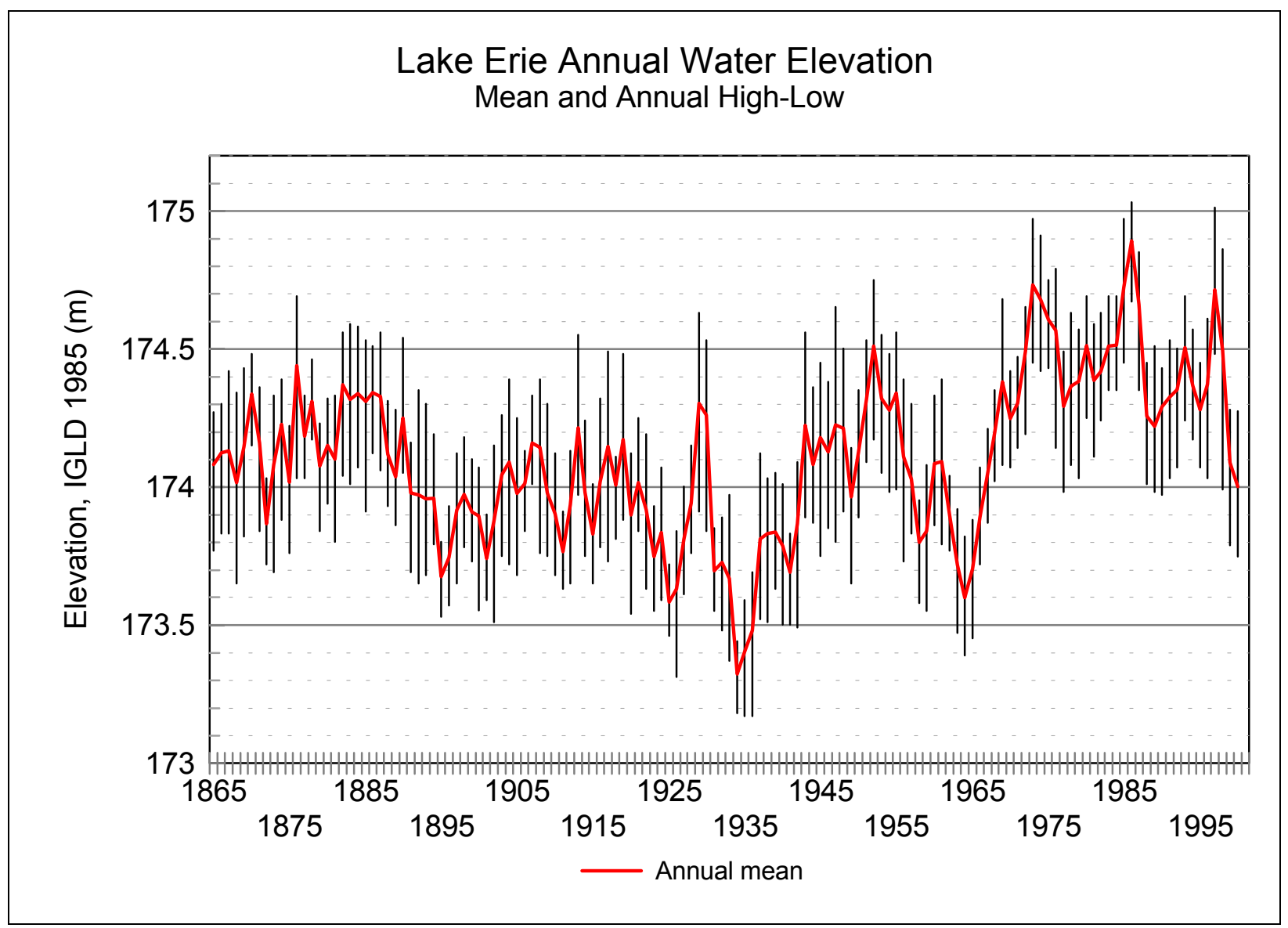

Figure 11. Mean annual Lake Erie water level from 1865 to present with high-low range shown with vertical bars. Plot clearly shows that water levels were anomalously high from late 1970s through 1998. Data from 1865-1917 are from a single measurement station, while 1918-2000 are a composite of eight stations (data from U.S. Army Engineer District, Detroit, originally from National Oceanic and Atmospheric Administration)

Accounts in the press suggest that the period of high water level in the 1980s and 1990s were marked by accelerated erosion throughout the Great Lakes. However, this was also a period of rapid residential and commercial growth on the lakes, and many homeowners, concerned by the destruction of their property, built shore protection structures of various degrees of engineering and quality. In addition, this period coincided with an era of significant inflation in the American economy, during which the lake shore property and the affluence of their owners increased greatly.

One year can make a surprising difference in water levels. In 1997 and 1998, levels were significantly above average (Figure 12). The high point was during June of 1997, when the elevation was about $0.7 \mathrm{~m}$ above the long-term (1918-1998) average. Starting in the fall of 1998, water levels began to drop to near or below average on the lakes. The winter of 1997 - 1998 was one of the mildest on record. The following year, 1998 - 1999, was near normal in terms of temperatures, but seasonal precipitation was below normal, particularly snowfall 


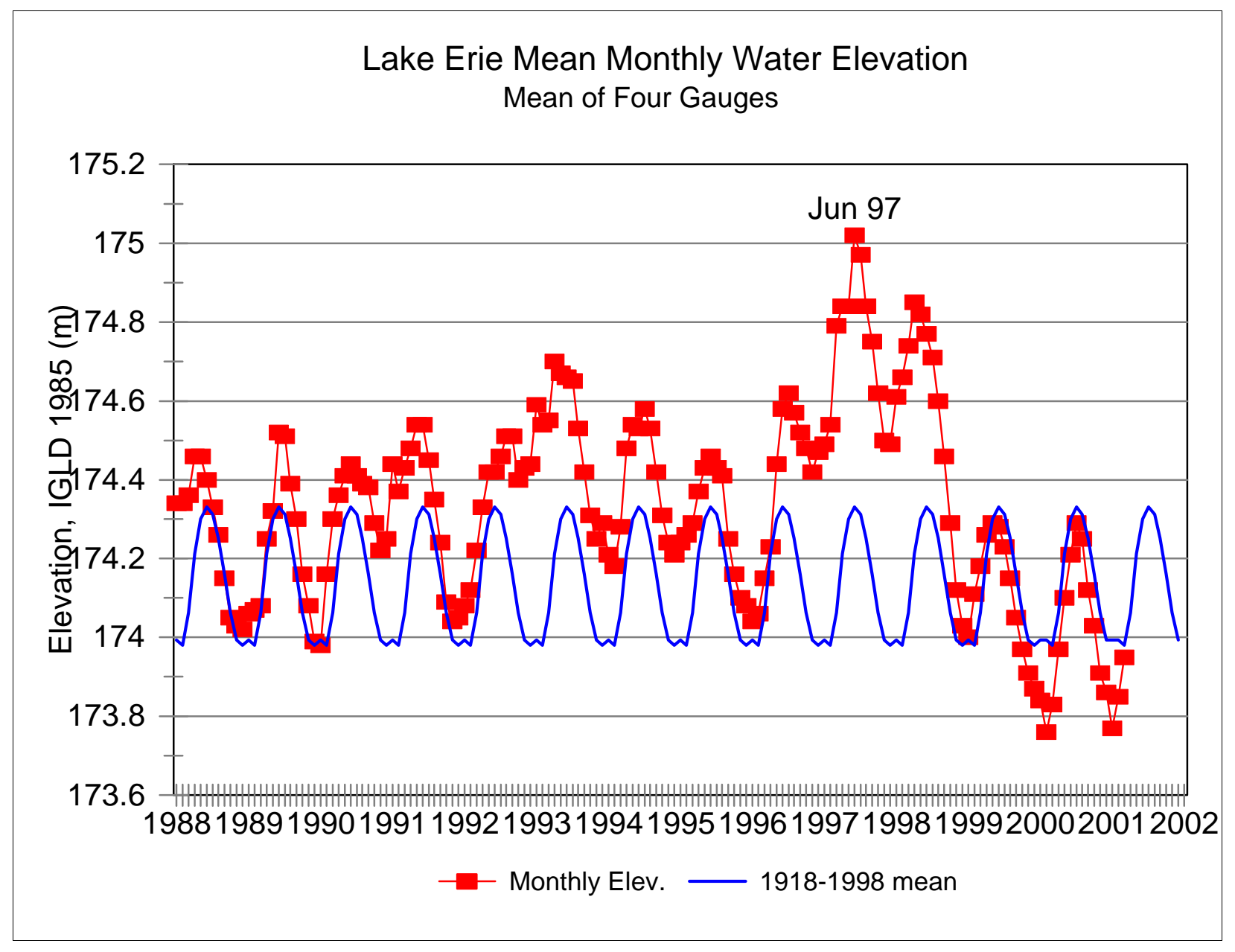

Figure 12. Lake Erie monthly mean water level, 1988-2001. Values based on gauges at Cleveland, Port Colborne, Port Stanley, and Toledo. (Monthly from Detroit District Web page: http://huron.Ire.usace.army.mil/levels/hleverie.html 1918-1998 mean: http://huron.Ire.usace.army.mil/levels/maxmin.html, 7 Feb 2000)

in the northern latitudes around Lakes Superior, Michigan, and Huron. Snowmelt is a key component of the Great Lakes hydrologic cycle that affects water levels. Water from melting snow saturates the ground or becomes overland runoff and flows into waterways and into the Great Lakes. The average monthly water level for Lake Erie in March 1999 was $0.6 \mathrm{~m}$ below what it was in March 1998 and was approximately at the long-term mean. Note that this level is still more than $1 \mathrm{~m}$ above the record low-water level for March, set in 1934. ${ }^{1}$ By January of 2000, the water level was at $173.84 \mathrm{~m}, 0.16 \mathrm{~m}$ below the longterm average and the lowest since the spring of 1967. During 2000, the level rose and then dropped back to 173.86 in January 2001. As a result, the beach east of the marina, particularly from about $250 \mathrm{~m}$ east of the east wall and extending east as far as the mouth of Twentymile Creek is wider now than it has been in about 10 years (Figure 13).

\footnotetext{
${ }^{1}$ Water level information from Detroit District Web page: http://www.lre.usace.army.mil/levels/summary/1999lwl.html
} 
the mouth of Twentymile Creek is wider now than it has been in about 10 years (Figure 13).

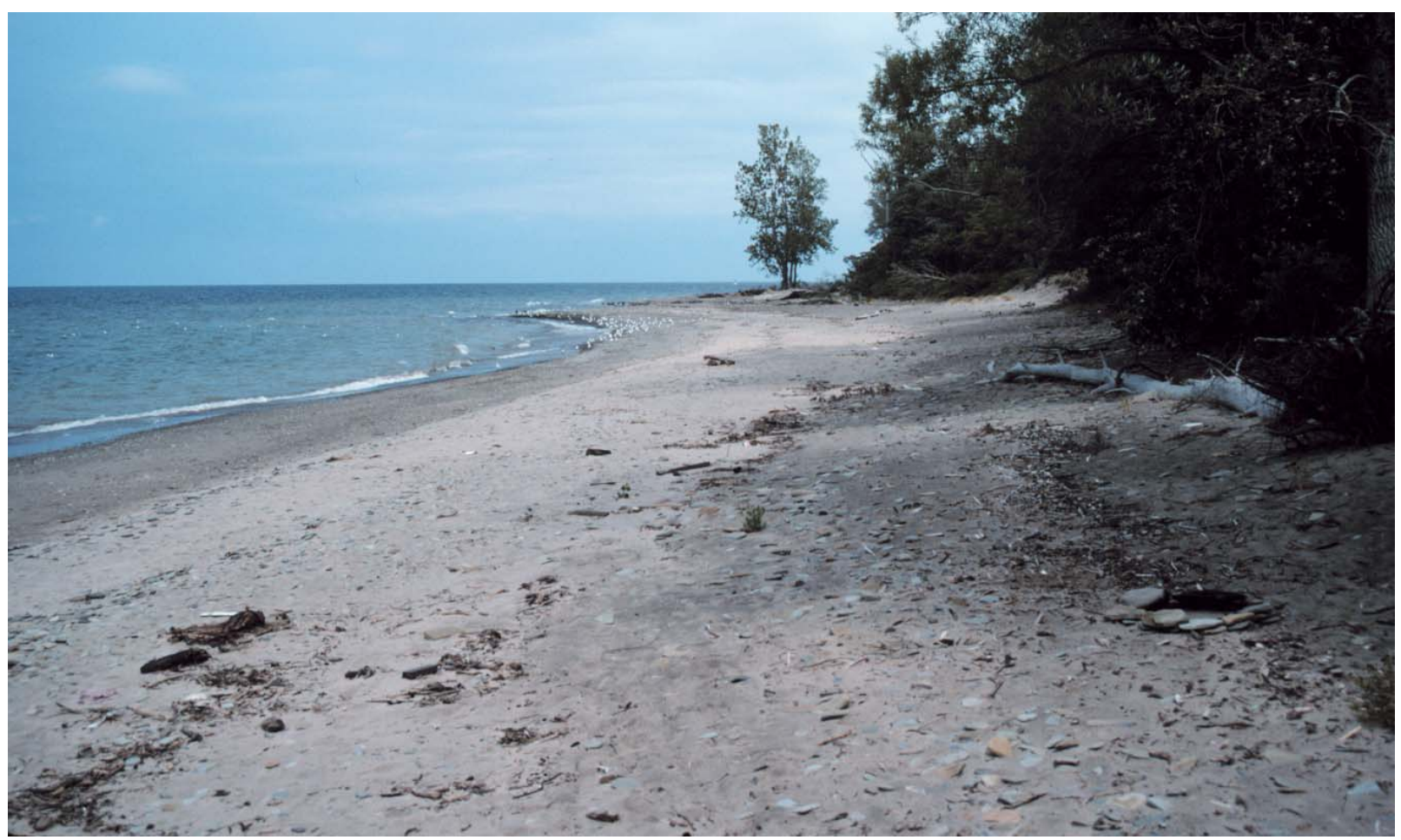

Figure 13. Sand beach west of Twentymile Creek, 1 August 1999. The expense of sand demonstrates the beneficial effect of falling lake level. This section of beach is fine sand with scattered cobble, but becomes completely cobble at the mouth of creek. Lone tree in distance is at bank of creek. PFBC employees reported that beach was widest they could recall in years

To model the effect of changing water level on beach width, a best fit curve was generated to closely match the bluffs and beach at profile line E1800 (Figure 14). The lower portion of the figure shows the width of the beach, defined from the top of the bluff to the waterís edge, in December 1999. Figure 15 shows the influence of water level on Profile E1800 during the last decade (assuming no changes in sediment, construction, or other external factors). As water level changes (upper curve), the beach shows the opposite response (lower curve). Beach width ranged from about $15.29 \mathrm{~m}$ to $36.57 \mathrm{~m}(50 \mathrm{ft}$ to $120 \mathrm{ft})$, and the rapid increase in width after April 1998, corresponding to the drop in lake water levels, is obvious in the lower curve.

\section{Bluff Erosion and Sediment Supply}

Before the industrial era, most of the Lake Erie shore had a substantial sediment supply because sediment eroded from bluffs and supplied by rivers remained in the littoral zone. When the first European settlers came to northern Ohio in 1796, the wide, continuous sandy beach of the lake was used as a road 

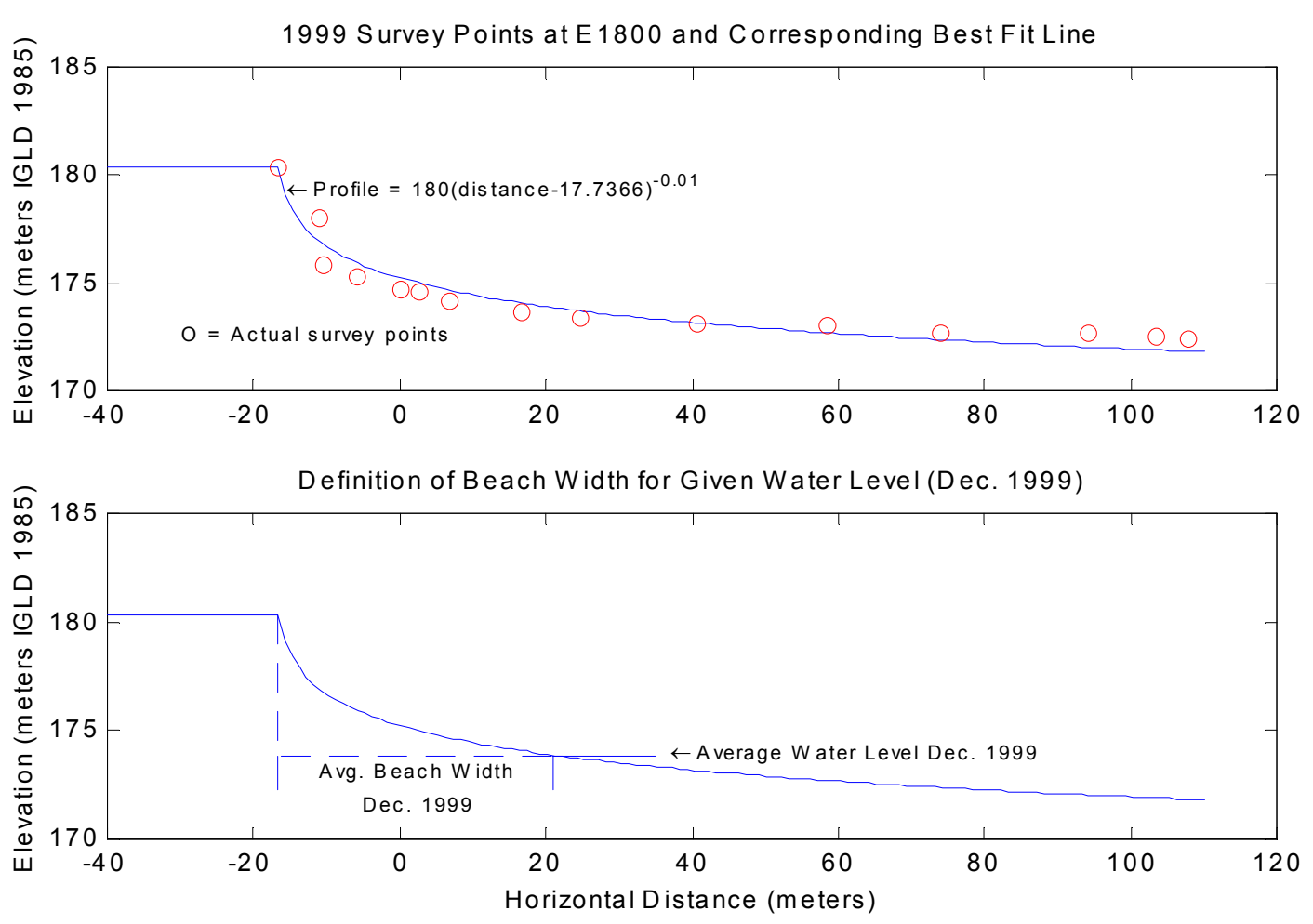

Figure 14. Best fit curve and modeled beach profile for Profile line E1800. Curve modeled using MatLab software

(Mather 1838). When lake level was high, in some areas bluffs were eroded by waves, resulting in additional sediment for the littoral system. In other areas, the beach was wide enough to protect the bluff, and sand on the shoreface was redistributed and moved along the coast. When lake level was low, sand from the lower portion of the shoreface was mobilized and became part of the littoral drift.

Today, the south shore of Lake Erie is severely sand-starved compared to the conditions that existed 200 years ago. The lack of available sediment is due to both natural and manmade causes. As the Lake Erie shore developed and became urbanized after the mid-1800s, residents, industries, and municipalities attempted to arrest bluff erosion using various forms of structures and vegetation. Some of these protection measures worked temporarily, but they aggravated the erosion problem by reducing the supply of sediment that could be reworked and transported along the shore by waves. Equally important were the jetties built at many harbors to stabilize the navigation entrances. At most of these harbors, sand accumulated in the fillets and navigation channels, from whence it was disposed in deep water, thereby further depriving the littoral system of sediment. 


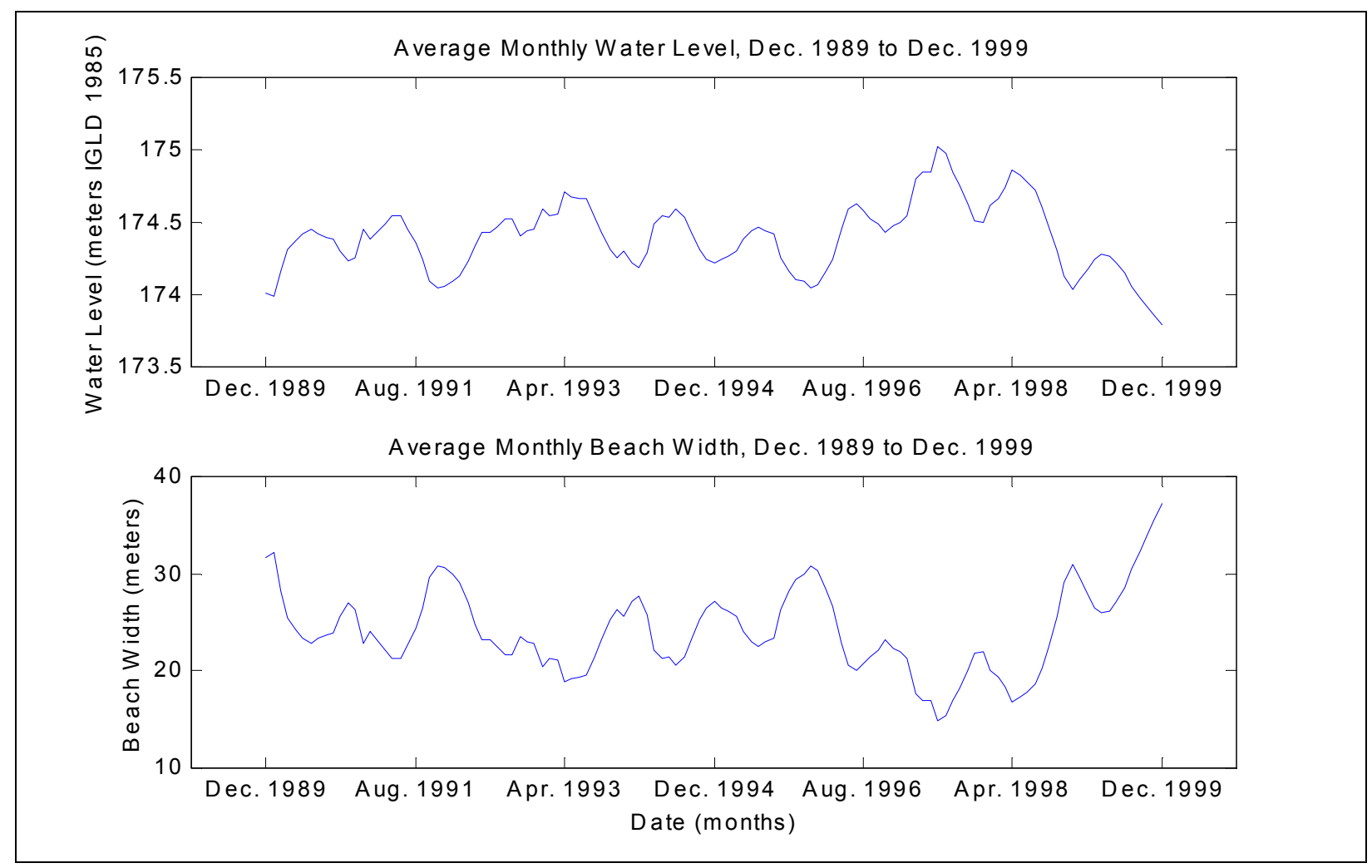

Figure 15. Variation of beach width at Profile Line E1800 corresponding to water level changes during the 1990s

The rate of bluff recession is difficult to quantify because of the varying quality of data available and the different time scales used in the computations. In 1994, the Detroit District sponsored the development of a comprehensive kilometer-by-kilometer database of recession rate data for the western U.S. Great Lakes shorelines (Stewart 1994). This database was based on all available shoreline recession rate data as of March 1994. The "Lower Great Lakes Erosion Study," currently being sponsored by Buffalo District, covers Lakes Ontario and Erie. This study did not identify any new recession data for the Pennsylvania shore (Stewart 1998).

Reaches 140 to 165 span the Pennsylvania shoreline from the New York border (140) to the east end of Erie (Figures 3, 4, and 5). Table 3 is a summary of the recession information for these reaches. For the North East Marina study site (No. 142, 143, and 144), over a period of a century, the mean recession rate in this vicinity was about $0.3 \mathrm{~m} /$ year, or a foot a year. The short-term recession rate for reach 143, where the marina is situated, computed for a 5-year period in the $1980 \mathrm{~s}$, was $0.2 \mathrm{~m} /$ year. Lake levels were generally high during the $1980 \mathrm{~s}$, so presumable this short-term recession rate might be higher than average.

Nevertheless, this short-term value is close to the 100 -year average, so it is reasonable to use $0.2 \mathrm{~m} /$ year as an average background recession rate for this region. 


\begin{tabular}{|c|c|c|c|c|c|c|}
\hline \multicolumn{7}{|c|}{\begin{tabular}{||l} 
Table 3 \\
Recession Rate Statistics for 1-km Reaches, Lake Erie, PA \\
(west to east)
\end{tabular}} \\
\hline Reach & Area $^{1}$ & $\begin{array}{l}\text { Mean recession } \\
\text { rate (m/year) }\end{array}$ & $\begin{array}{l}\text { Years of } \\
\text { record }\end{array}$ & $\begin{array}{l}\text { Data } \\
\text { type }\end{array}$ & Confidence $^{3}$ & $\begin{array}{l}\text { Original } \\
\text { source }\end{array}$ \\
\hline \multirow[t]{2}{*}{166} & \multirow[t]{2}{*}{$\begin{array}{l}\text { Lawrence } \\
\text { Park, Erie }\end{array}$} & 0.93 & $1939-1975$ & 1 & 3 & $\begin{array}{l}\text { Knuth and } \\
\text { Crowe } 1975\end{array}$ \\
\hline & & 0.37 & $1982-1986$ & 1 & 1 & Knuth 1987 \\
\hline \multirow[t]{2}{*}{165} & \multirow[t]{2}{*}{ Fairfield } & 0.09 & $1939-1975$ & 1 & 3 & $\begin{array}{l}\text { Knuth and } \\
\text { Crowe } 1975\end{array}$ \\
\hline & & 0.03 & $1982-1986$ & 1 & 1 & Knuth 1987 \\
\hline \multirow[t]{2}{*}{164} & \multirow[t]{2}{*}{ Fairfield } & 0.27 & $1939-1975$ & 1 & 3 & $\begin{array}{l}\text { Knuth and } \\
\text { Crowe } 1975\end{array}$ \\
\hline & & 0.27 & $1982-1986$ & 1 & 1 & Knuth 1987 \\
\hline \multirow[t]{2}{*}{163} & \multirow[t]{2}{*}{ E. of Fairfield } & 0.20 & $1939-1975$ & 1 & 3 & $\begin{array}{l}\text { Knuth and } \\
\text { Crowe } 1975\end{array}$ \\
\hline & & 1.10 & $1982-1986$ & 1 & 1 & Knuth 1987 \\
\hline 162 & & 0.24 & $1939-1975$ & 1 & 3 & $\begin{array}{l}\text { Knuth and } \\
\text { Crowe } 1975\end{array}$ \\
\hline 161 & & 0.27 & $1939-1975$ & 1 & 3 & $\begin{array}{l}\text { Knuth and } \\
\text { Crowe } 1975\end{array}$ \\
\hline \multirow[t]{2}{*}{160} & \multirow{2}{*}{$\begin{array}{l}\text { Between } \\
\text { Eightmile and } \\
\text { unnamed } \\
\text { creek }\end{array}$} & 0.13 & $1939-1975$ & 1 & 3 & $\begin{array}{l}\text { Knuth and } \\
\text { Crowe } 1975\end{array}$ \\
\hline & & 0.43 & $1977-1986$ & 1 & 1 & Knuth 1987 \\
\hline \multirow[t]{2}{*}{159} & \multirow{2}{*}{$\begin{array}{l}\text { Eightmile } \\
\text { Creek - Scott } \\
\text { Run }\end{array}$} & 0.30 & 100 yrs. & 4 & 4 & $\begin{array}{l}\text { Carter et al. } \\
1987\end{array}$ \\
\hline & & 0.00 & $1982-1986$ & 1 & 1 & Knuth 1987 \\
\hline \multirow[t]{2}{*}{158} & \multirow{2}{*}{$\begin{array}{l}\text { Just E. of } \\
\text { Eightmile } \\
\text { Creek }\end{array}$} & 0.13 & $1939-1975$ & 1 & 3 & $\begin{array}{l}\text { Knuth and } \\
\text { Crowe } 1975\end{array}$ \\
\hline & & 0.00 & $1982-1986$ & 1 & 1 & Knuth 1987 \\
\hline & & & & & & (Sheet 1 of 3 ) \\
\hline \multicolumn{7}{|c|}{$\begin{array}{l}1 \text { Locations of reaches shown in Figures } 3,4 \text {, and } 5 \\
2 \text { Data type: } \\
1 \text { = Linear zone range value, represents average recession within a zone along the shore. } \\
2 \text { = Point location, rate for reach was calculated at single profile location } \\
3 \text { Confidence: } \\
1=\text { "Accurate," meaning data that was acquired through direct surveying, with superior quality } \\
\text { control, and is used for state setback determinations or other planning and engineering analyses. } \\
3=\text { "Moderately certain" - data generated through analysis of moderate quality maps or air } \\
\text { photographs, with appropriate quality control. } \\
4=\text { "Reasonable inference" - data is largely judgmental, based on rescaled } 1875 \text { maps and } 1939 \\
\text { and } 1974 \text { aerial photographs } \\
\text { Source: Lower Great Lakes Erosion Study (Stewart 1998) }\end{array}$} \\
\hline
\end{tabular}




\begin{tabular}{|c|c|c|c|c|c|c|}
\hline \multicolumn{7}{|c|}{ |Table 3 (Continued) } \\
\hline Reach & Area $^{1}$ & $\begin{array}{l}\text { Mean recession } \\
\text { rate (m/year) }\end{array}$ & $\begin{array}{l}\text { Years of } \\
\text { record }\end{array}$ & $\begin{array}{l}\text { Data } \\
\text { type }\end{array}$ & Confidence $^{3}$ & $\begin{array}{l}\text { Original } \\
\text { source }\end{array}$ \\
\hline \multirow[t]{2}{*}{$\mid 157$} & & 0.13 & $1939-1975$ & 1 & 3 & $\begin{array}{l}\text { Knuth and } \\
\text { Crowe } 1975\end{array}$ \\
\hline & & 0.00 & $1982-1986$ & 1 & 1 & Knuth 1987 \\
\hline \multirow[t]{2}{*}{ ||156 } & \multirow{2}{*}{$\begin{array}{l}\text { W. of } \\
\text { Twelvemile } \\
\text { Creek }\end{array}$} & 0.07 & $1939-1975$ & 1 & 3 & $\begin{array}{l}\text { Knuth and } \\
\text { Crowe } 1975\end{array}$ \\
\hline & & 0.00 & $1982-1986$ & 1 & 1 & Knuth 1987 \\
\hline \multirow[t]{2}{*}{ ||155 } & \multirow[t]{2}{*}{$\begin{array}{l}\text { Twelvemile } \\
\text { Creek }\end{array}$} & 0.30 & 100 yrs. & 4 & 4 & $\begin{array}{l}\text { Carter et al. } \\
1987\end{array}$ \\
\hline & & 0.13 & $1982-1987$ & 1 & 1 & Knuth 1987 \\
\hline $\mid 154$ & $\begin{array}{l}\text { Just E. of } \\
\text { Twelvemile } \\
\text { Creek }\end{array}$ & 0.31 & $1939-1975$ & 1 & 3 & $\begin{array}{l}\text { Knuth and } \\
\text { Crowe } 1975\end{array}$ \\
\hline $\mid 153$ & & 0.29 & $1939-1975$ & 1 & 3 & $\begin{array}{l}\text { Knuth and } \\
\text { Crowe } 1975\end{array}$ \\
\hline $\mid 152$ & & 0.44 & $1939-1975$ & 1 & 3 & $\begin{array}{l}\text { Knuth and } \\
\text { Crowe } 1975\end{array}$ \\
\hline \multirow[t]{2}{*}{|| 151} & & 0.16 & $1939-1975$ & 1 & 3 & $\begin{array}{l}\text { Knuth and } \\
\text { Crowe } 1975\end{array}$ \\
\hline & & 0.12 & $1982-1986$ & 1 & 1 & Knuth 1987 \\
\hline \multirow[t]{2}{*}{$\mid 150$} & & 0.30 & 100 yrs. & 4 & 4 & $\begin{array}{l}\text { Carter et al. } \\
1987\end{array}$ \\
\hline & & 0.00 & $1982-1986$ & 1 & 1 & Knuth 1987 \\
\hline $\mid 149$ & & 0.21 & $1939-1975$ & 1 & 3 & $\begin{array}{l}\text { Knuth and } \\
\text { Crowe } 1975\end{array}$ \\
\hline $\mid 148$ & $\begin{array}{l}\text { W. of } \\
\text { Freeport }\end{array}$ & 0.05 & $1939-1975$ & 1 & 3 & $\begin{array}{l}\text { Knuth and } \\
\text { Crowe } 1975\end{array}$ \\
\hline \multirow[t]{2}{*}{$\mid 147$} & \multirow[t]{2}{*}{ Freeport } & 0.30 & 100 yrs. & 4 & 4 & $\begin{array}{l}\text { Carter et al. } \\
1987\end{array}$ \\
\hline & & 0.00 & $1982-1986$ & 1 & 1 & Knuth 1987 \\
\hline \multirow[t]{2}{*}{ ||146 } & \multirow{2}{*}{$\begin{array}{l}\text { Orchard } \\
\text { Beach, } \\
\text { Sixteenmile } \\
\text { Creek }\end{array}$} & 0.12 & $1939-1975$ & 1 & 3 & $\begin{array}{l}\text { Knuth and } \\
\text { Crowe } 1975\end{array}$ \\
\hline & & 0.00 & $1982-1986$ & 1 & 1 & Knuth 1987 \\
\hline \multirow[t]{2}{*}{$\mid 145$} & & 0.20 & $1939-1975$ & 1 & 3 & $\begin{array}{l}\text { Knuth and } \\
\text { Crowe } 1975\end{array}$ \\
\hline & & 0.00 & $1982-1986$ & 1 & 1 & Knuth 1987 \\
\hline
\end{tabular}




\begin{tabular}{|c|c|c|c|c|c|c|}
\hline \multicolumn{7}{|c|}{ Table 3 (Concluded) } \\
\hline Reach & Area $^{1}$ & $\begin{array}{l}\text { Mean recession } \\
\text { rate (m/year) }\end{array}$ & $\begin{array}{l}\text { Years of } \\
\text { record }\end{array}$ & $\begin{array}{l}\text { Data } \\
\text { type }\end{array}$ & Confidence $^{3}$ & $\begin{array}{l}\text { Original } \\
\text { source }\end{array}$ \\
\hline \multirow[t]{2}{*}{$\mid 144$} & \multirow[t]{2}{*}{ North East } & 0.30 & 100 yrs. & 4 & 4 & Carter et al. \\
\hline & & 0.77 & $1982-1986$ & 1 & 1 & Knuth 1987 \\
\hline \multirow[t]{2}{*}{|| 143} & \multirow[t]{2}{*}{ NE Marina } & 0.05 & $1939-1975$ & 1 & 3 & $\begin{array}{l}\text { Knuth and } \\
\text { Crowe } 1975\end{array}$ \\
\hline & & 0.20 & $1982-1986$ & 1 & 1 & Knuth 1987 \\
\hline \multirow[t]{2}{*}{|| 142} & \multirow[t]{2}{*}{$\begin{array}{l}\text { Twentymile } \\
\text { Creek }\end{array}$} & 0.30 & 100 yrs. & 4 & 4 & $\begin{array}{l}\text { Carter et al. } \\
1987\end{array}$ \\
\hline & & 0.06 & $1982-1986$ & 1 & 1 & Knuth 1987 \\
\hline $\mid 141$ & & 0.41 & $1939-1975$ & 1 & 3 & $\begin{array}{l}\text { Knuth and } \\
\text { Crowe } 1975\end{array}$ \\
\hline $\mid 140$ & $\begin{array}{l}\text { NY - PA } \\
\text { border }\end{array}$ & 0.04 & $1875-1974$ & 1 & 3 & \begin{tabular}{|l} 
Geier and \\
Calkin 1983
\end{tabular} \\
\hline \multirow[t]{2}{*}{$\mid$ ||139 } & \multirow[t]{2}{*}{$\begin{array}{l}\text { E. of NY state } \\
\text { line }\end{array}$} & 0.08 & $1875-1979$ & 1 & 3 & $\begin{array}{l}\text { NY Dep. of } \\
\text { Env. } \\
\text { Conservation }\end{array}$ \\
\hline & & 0.13 & $1875-1974$ & 1 & 1 & $\begin{array}{l}\text { Geier and } \\
\text { Calkin } 1983\end{array}$ \\
\hline
\end{tabular}

The relationship between lake level and bluff recession is complicated and very much subject to local geology and shore geometry. As long as the long-term meteorological and hydrographic factors that determine wave energy remain the same, the long-term erosion rate will remain essentially unchanged (International Joint Commission 1993). Lake level does, however, have an effect on where wave energy is dissipated on the beach profile, and thus may affect bluff recession rates over a short period.

During periods of rapidly declining water levels, a wider dry beach is exposed, and sand appears to be in ample supply. This phenomenon is not constant nor permanent. Over periods of stable water levels, even at a lower profile, beach erosion can occur, particularly during storms. However, wider beaches serve as a natural armoring feature, and therefore, under lower water level conditions, the toe of the bluff is protected from wave activity and erosion will be temporarily reduced in some areas. This condition is not universal, however, since bluff collapses occur completely independent of lake levels and wave attack. ${ }^{1}$ Bluff failures occur as a result of groundwater seepage and geotechnical failures.

Table 3 showed that at least 30 percent of most bluffs between Erie and the New York border consist of clay and silt. As the bluffs erode, the fine-grained

\footnotetext{
1 Modified from Detroit District Web page: http://huron.lre.usace.army.mil/levels/summary/1999lwl.html (30 Jan 2000).
} 
material enters the water column and is carried alongshore by currents. When waves are greater than 20 or $30 \mathrm{~cm}$, the water around North East Marina is too turbid for the bottom to be visible in aerial photographs, but on a waveless day, the water is clear enough to see the bottom 2-3 m down. One significant loss of fine-grained sediment from Lake Erie is the Niagara River, which carries about 5 million tons/year of suspended sediment (Carter 1977). Lake Erie residents state that overall water clarity has improved dramatically since the 1980s because of the proliferation of filter-feeding zebra mussels.

In summary, the bluffs along the Pennsylvania shore of Lake Erie have been retreating at least as long as maps and written records have been available. The background recession rate in the region immediately surrounding North East Marina is about $0.2 \mathrm{~m} / \mathrm{year}$ based on the long-term records summarized in Table 3. This suggests that in the 10 years since the marina was built, the bluffs in this area could be expected to have retreated about $2 \mathrm{~m}$ under "natural" conditions (i.e., without shore protection or artificially-supplied beach fill). Between Erie and North East, the background recession without stabilization structures would have ranged from $1 \mathrm{~m}$ to over $4 \mathrm{~m}$ over 10 years (see Table 3 ).

\section{Manmade Structures}

Presently, a variety of artificial structures can be seen along the shore starting about $240 \mathrm{~m}$ east of the marina (Figure 16). Before the present marina facility was built, a number of property owners in the area of the original boat ramp erected shore armoring structures, such as timber walls, gabions, and concretefilled barrels (Figures 17-22). This clearly indicates that shore and bluff retreat have been a continuing problem in this area and that homeowners felt it necessary to attempt to reduce mass wasting and protect the bluffs from wave attack. Most homes in this area were built at the top of the bluffs, but a few cottages were built either completely on the beach or on the transition zone between low bluff and the beach. One property like this is seen in Figure 21 and three more in Figure 22. When lake level was higher, the protective barrels and seawalls in front of the first cottage projected out into the lake like a peninsula (Figures 16 and 19).

Structures also existed west of the marina in the early 1990s, but these are now either covered with the sand and gravel that has accumulated in the updrift fillet or are a considerable distance from the present shore. Figure 23, taken in 1991, shows a wall made of concrete-filled grape juice tanks and a boat ramp in a view looking west from the marina. ${ }^{1}$

\footnotetext{
${ }^{1}$ Surplus steel tanks from the grape juice processing factory have been used in a number of locations between Erie and the NY border as shore protection.
} 


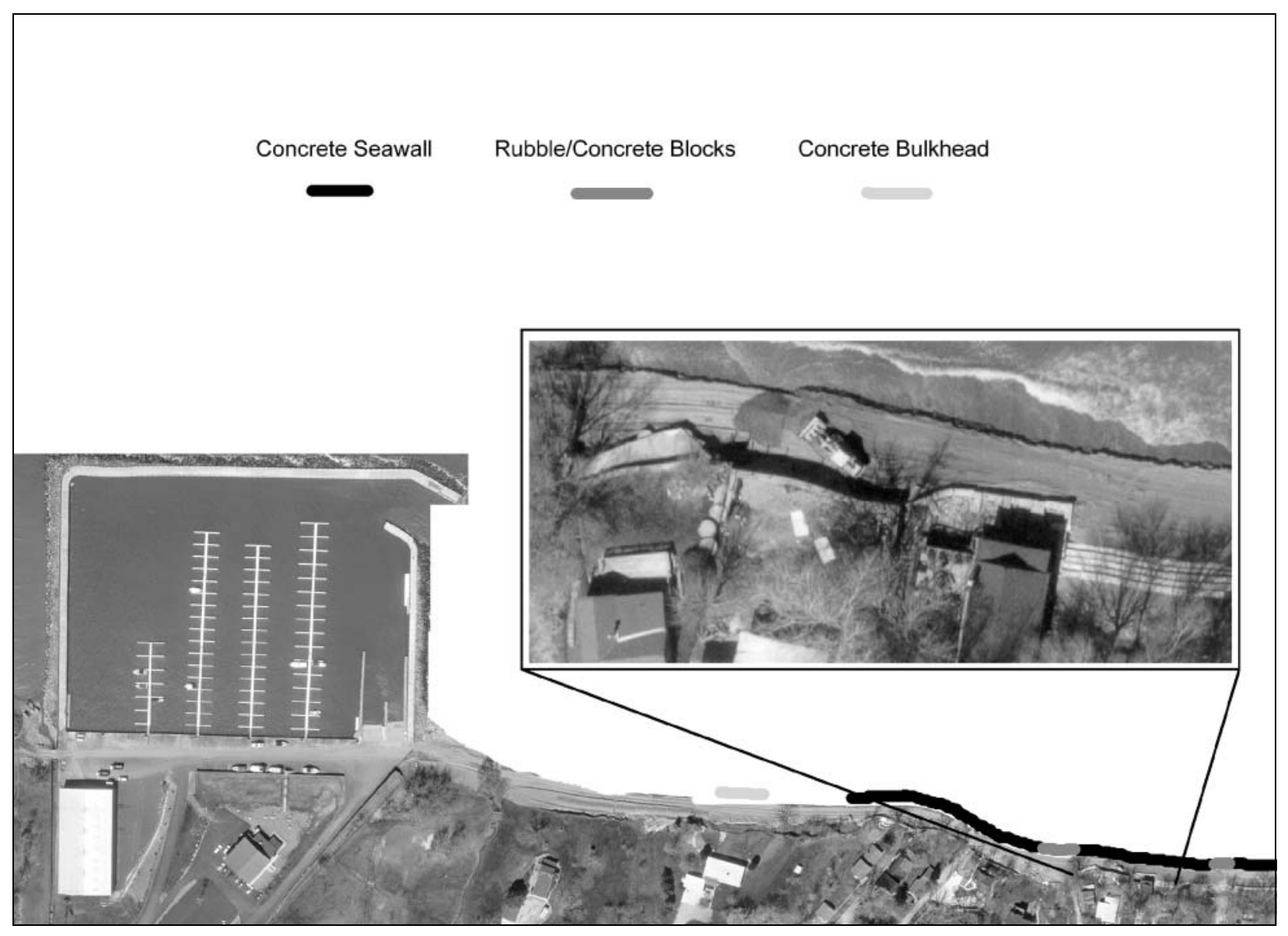

Figure 16. Armoring structures along the shore east of North East Marina (28 April 1999). All of these structures predate the marina. Insert shows a grader moving sand near one of the seawalls that project out from the bluff line 


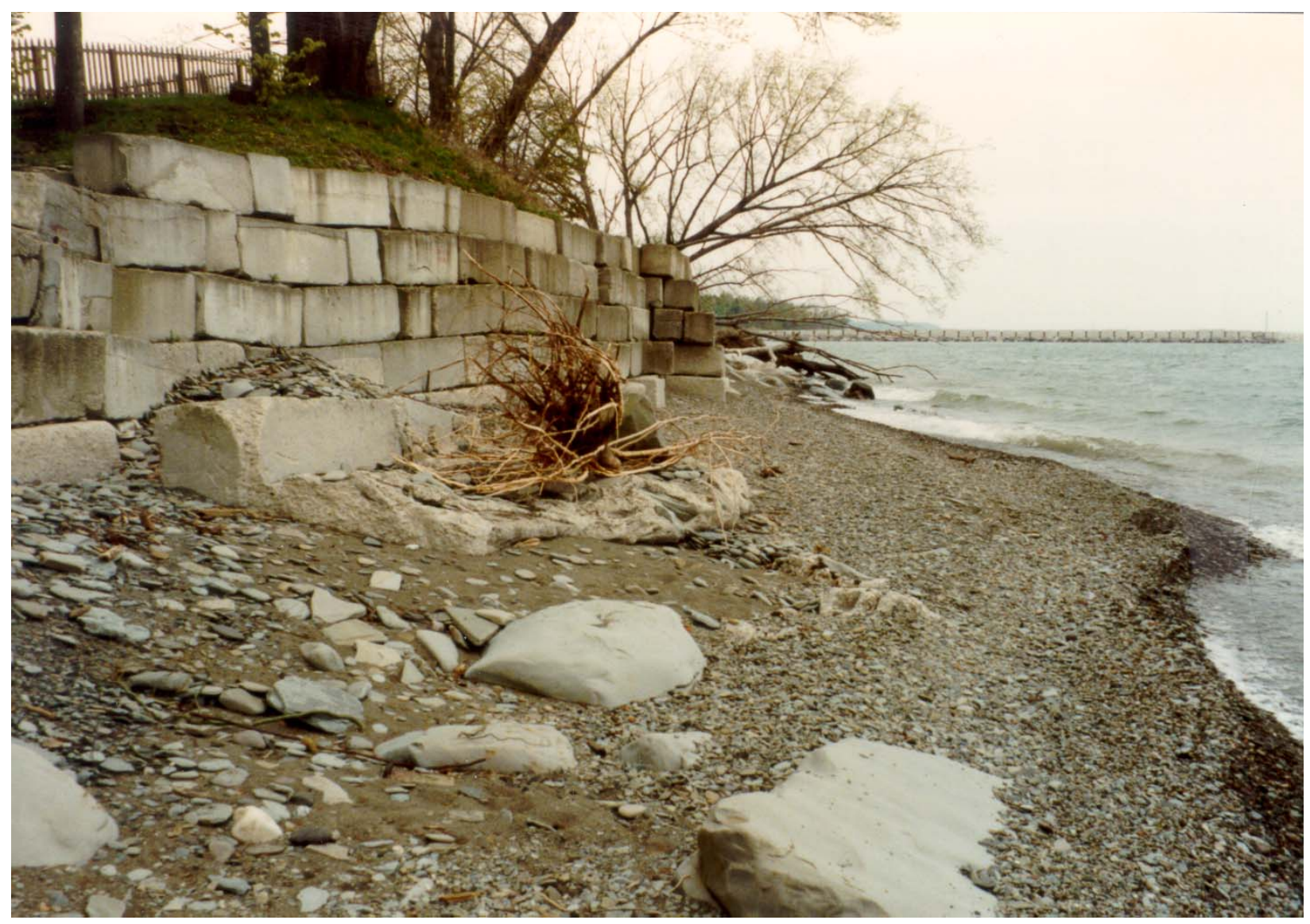

Figure 17. Concrete block wall about $200 \mathrm{~m}$ east of marina, 17 May 1991. Leaning tree is seen in subsequent figures 


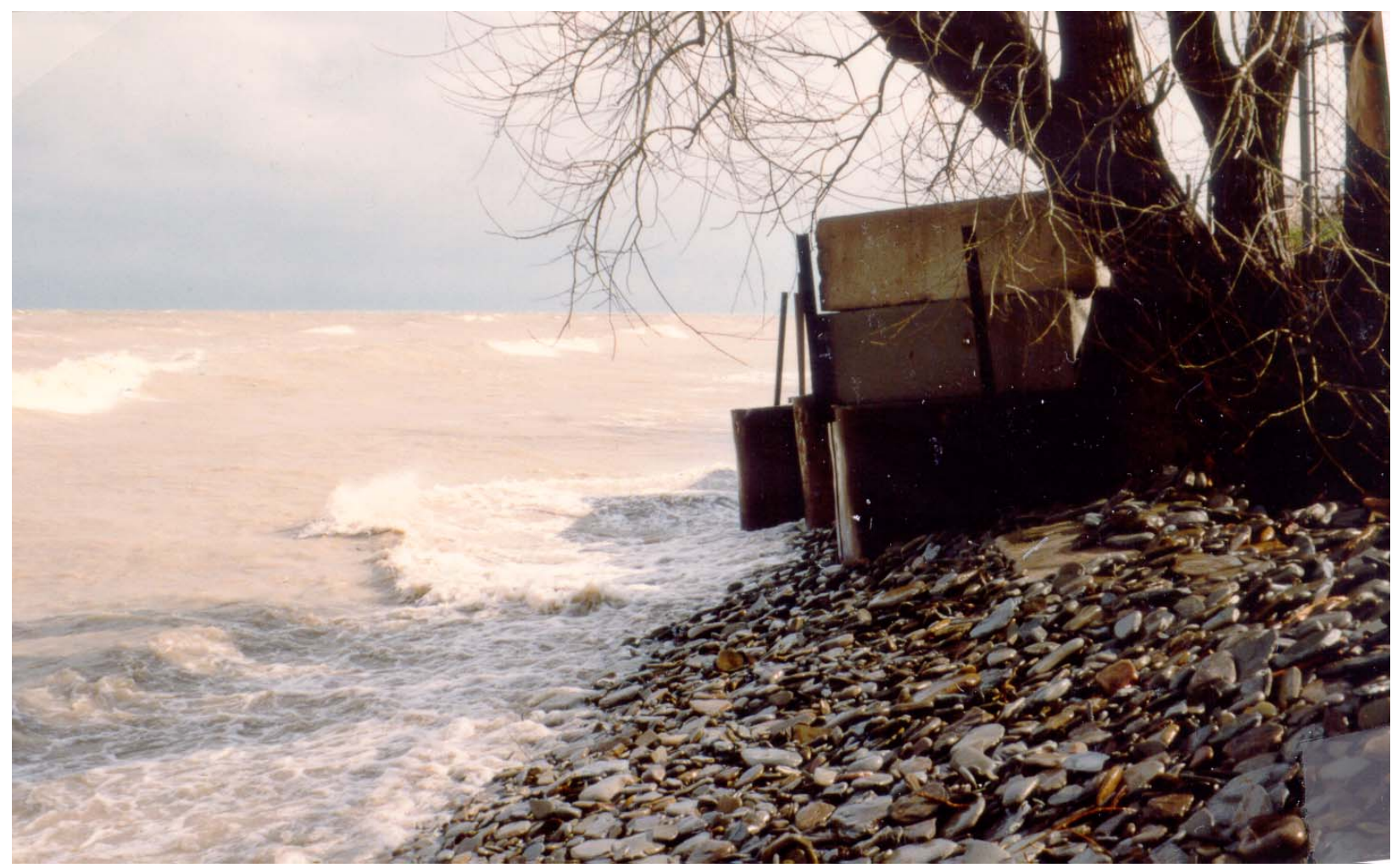

Figure 18. Exposed seawall March 1991, view east. Original photograph label states, "High water from storm just east of Kelley property" (Buffalo District archives) 


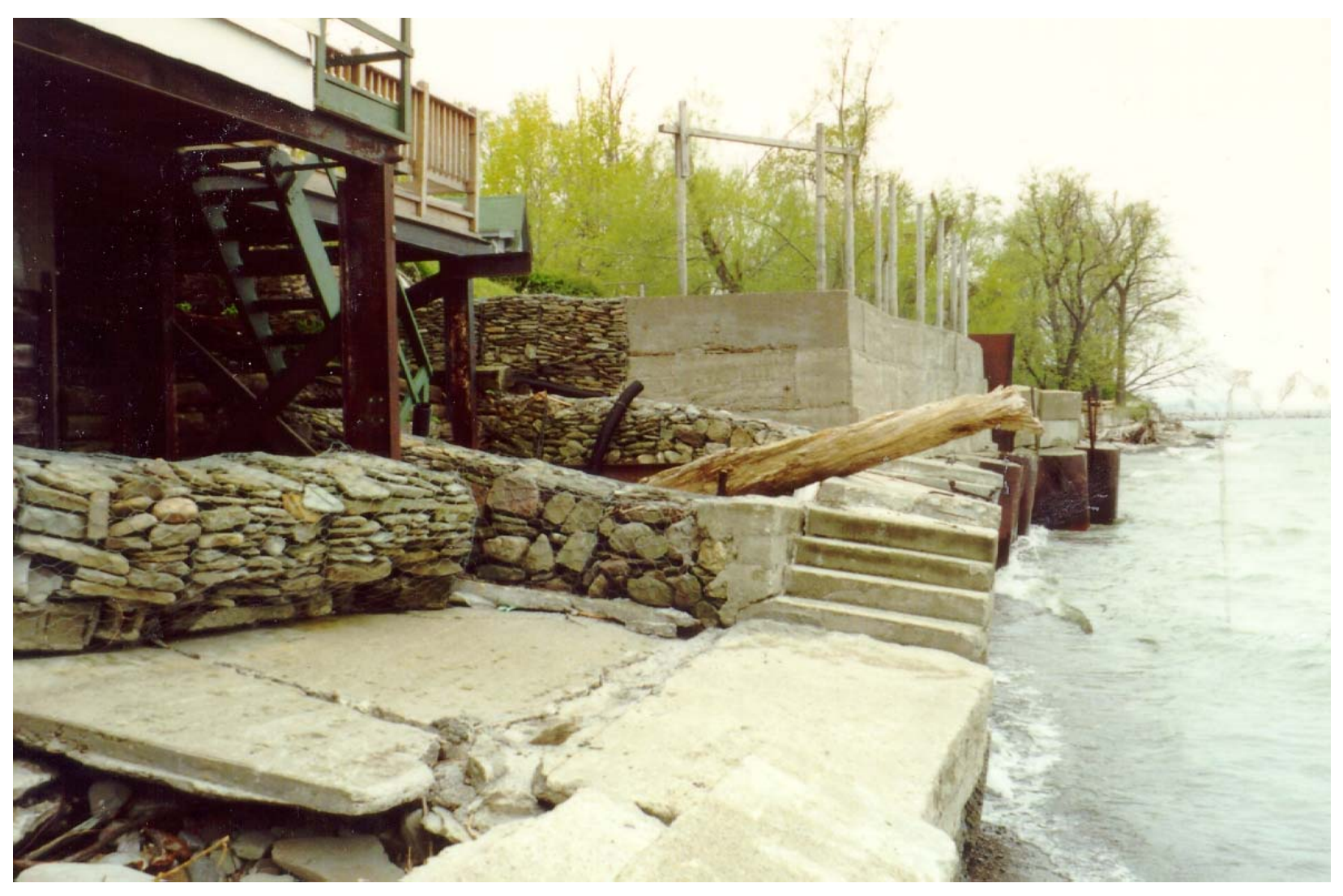

Figure 19. House protected with gabions, concrete, and concrete-filled tanks, May 1991. These structures are about $500 \mathrm{~m}$ east of marina's east wall (visible in right side of photograph). Notice tree trunk resting on wall next to steps, evidence of power of storm waves. When this photograph was taken, there was no beach at base of concrete slabs. Photograph from Buffalo District archives 


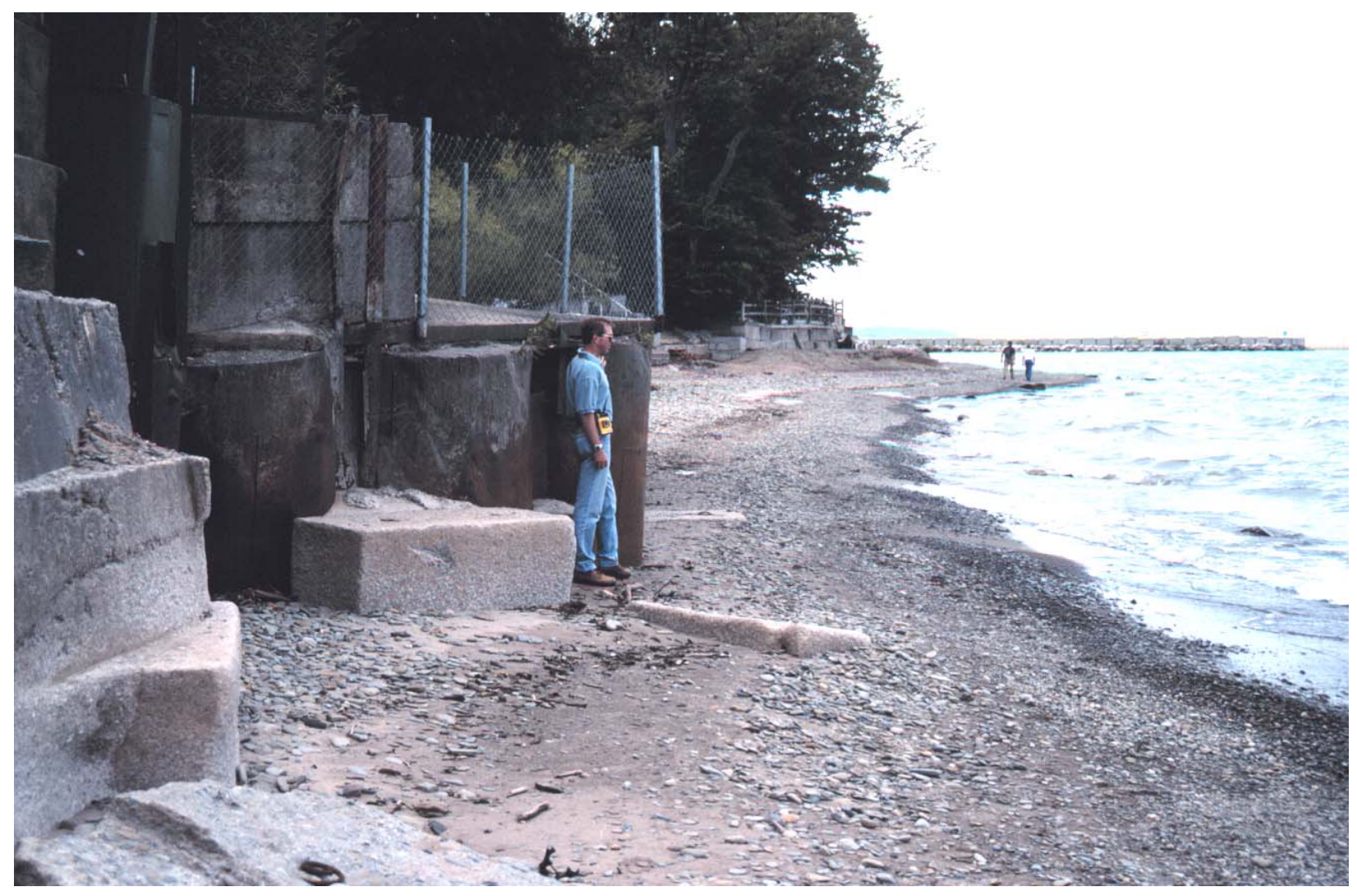

Figure 20. Gravel and sand beach below same structures shown in Figure 19. Beach is about $4 \mathrm{~m}$ wide. North East Marina east wall is in distance to right. Photograph taken 11 August 1999, before the autumn bypassing 


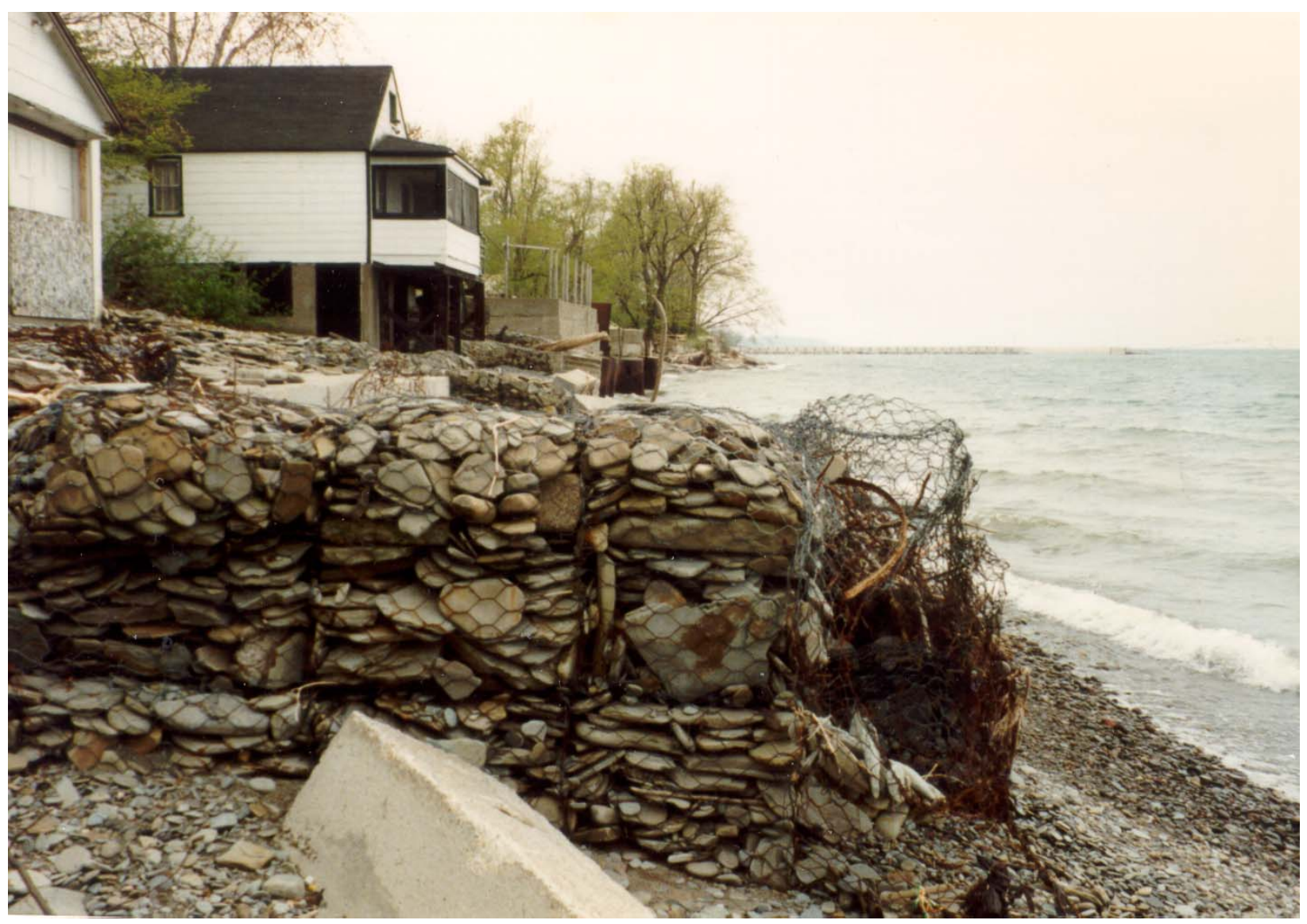

Figure 21. Gabion wall east of property shown in previous photographs, 17 May 1991. Leaning tree where concrete block walls are found is in distance. Photograph from Buffalo District archives 


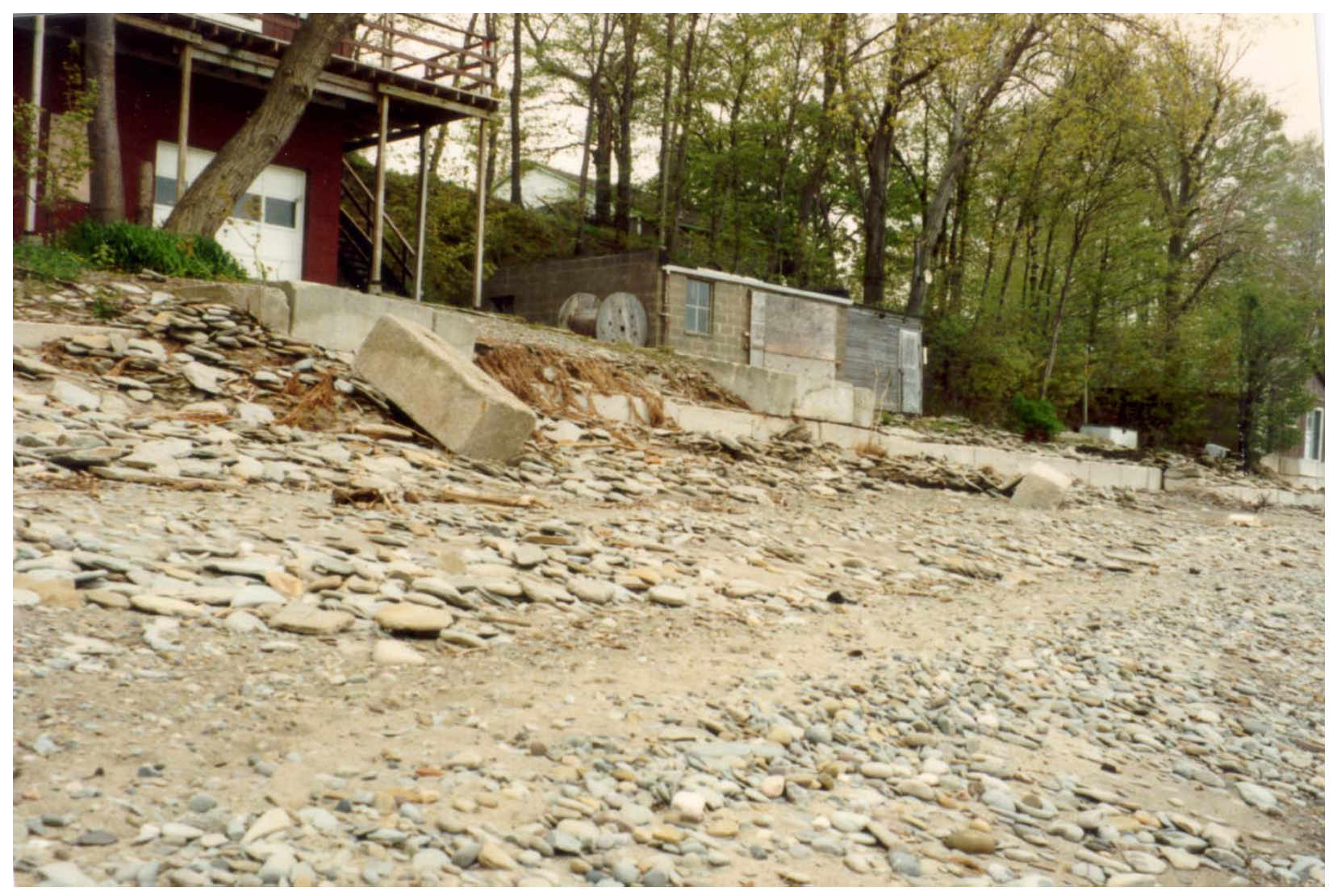

Figure 22. Cottage with protective concrete blocks east of the location shown in previous figures, 17 May 1991. Note the block that has been moved by storm waves. The three properties in the foreground are vulnerable to storm waves because they were built on the beach rather than up on the bluff like the house in the background. Photograph from Buffalo District archives 


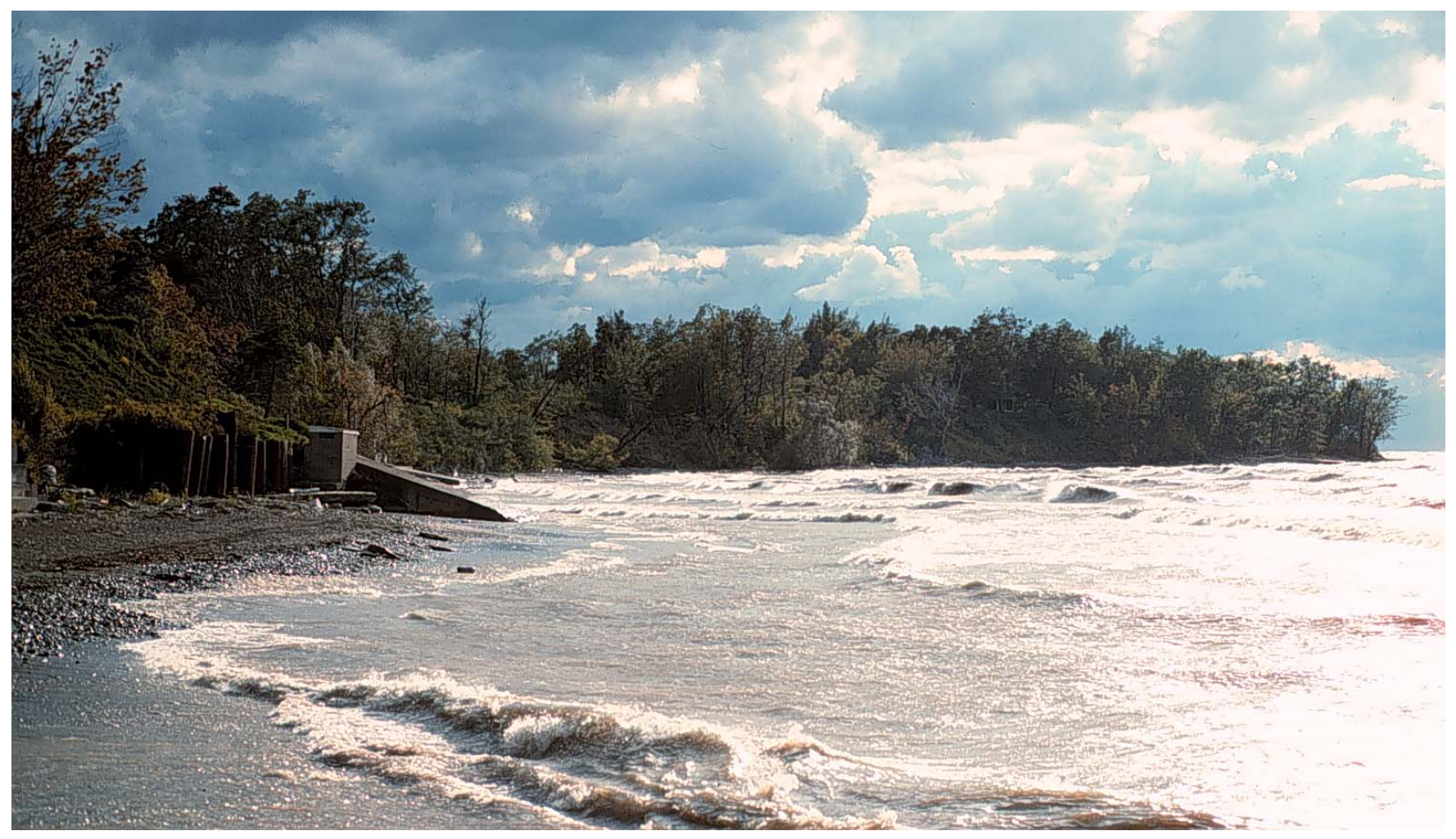

Figure 23. Seawall made of concrete-filled tanks west of North East Marina, November 1991. Most of the ramp and over two thirds of wall are now covered with sand and gravel. In 1991, beyond the walls, there was essentially no beach and waves broke directly at base of bluffs 


\section{Project History and Sand Bypassing}

Pennsylvania Fish Commission first purchased land at North East in 1963, and a boat-launching ramp has existed at the site of the present marina since 1967. In the mid-1980s, a private developer planned a recreational boating facility to be built on 13 acres of land leased from the PFBC. In May 1990, permits for the construction of the facility by Safe Harbor Marina, Inc., were approved and endorsed by the Buffalo District and PFBC. See Table A1 for a chronological list of historical events and sand bypassing at North East Marina.

The marina was designed and built by Simmons \& Associates of North East, PA. Construction, which began in spring of 1990, proved troublesome, and costs had been greatly underestimated. The construction company excavated about $4,000 \mathrm{yd}^{3}$ of material, ${ }^{1}$ some of it bedrock, from the inner marina. The breakwater, docks, and buildings were completed in 1992 after an expenditure of about $\$ 5,000,000 .^{2}$ After only two seasons, Safe Harbor Marina, Inc., ceased operations and abandoned the leased facilities. Eventually, PFBC acquired the buildings and equipment for about $\$ 700,000$ (the state already owned the land). Because of complications caused by the Corps requirement to bypass sediment and the lawsuit alleging downdrift erosion, no private operators were willing to lease the facility, and the PFBC assumed operations of the facilities in 1994.

The marina basin is surrounded by an L-shaped concrete breakwater that extends from the shore out into the water (Figures 6 and 7). The breakwater is about $570 \mathrm{~m}$ long and is protected on the lake side with stone riprap. The onshore facilities include a boat storage building, administration building, restaurant, fuel dock, sewage treatment plant, and maintenance shed. Two boat ramps and a large parking lot are available to the public and enjoy heavy use during summer weekends. Four floating docks contain 214 wet slips, and during the 1996 boating season (May through November), 143 of the slips were occupied. To improve flushing in the basin, a number of openings made of

\footnotetext{
1 To comply with comon useage all sand volumes are in cubic yards. To convert cubic yards to cubic meters, multiply by 0.7645 .

2 PFBC, briefing paper, 13 Feb. 1998.
} 
culvert pipe were built into the west breakwater, but these openings are now plugged with wood and debris.

Before construction began, a commercial survey company surveyed the beach along a series of shore-perpendicular profiles spaced $23 \mathrm{~m}(75 \mathrm{ft})$ apart. The recent surveys made during the September 1999 field study replicated the locations and azimuths of these original profiles, therefore allowing direct comparison. Coverage and dates of all available profiles are listed in Appendix C.

As soon as the west wall was built, sand started accumulating to the west in the form of a fillet. The original marina owner bypassed sand by truck twice in 1991 and attempted to hydraulically bypass sand in January 1993 using a Pekor jet pump. Jet pumps have been effective in sandy coasts such as Florida, but the experiment at North East Marina was unsuccessful for three operational reasons:

a. The operation was scheduled during the winter and the pipes froze.

$b$. There was too much cobble and gravel in the mix for the size of the pipes and the pumps to move.

c. It proved difficult to maneuver the pipes over and beyond ice ridges that form along the lakefront in winter.

After Safe Harbor Marina, Inc., ceased operations, the PFBC took over operation of the facility and immediately took steps to comply with the Corpsí permit. Removing the breakwater walls and restoring the site to its original condition was one alternative considered to reinstate natural bypassing, but this option would have cost over $\$ 2,000,000$, and there clearly was a need for a marina and harbor of refuge in this vicinity. Instead, in October of 1993, the PFBC purchased 12,000 $\mathrm{yd}^{3}$ of sand from an upland site at a cost of almost $\$ 100,000$ and placed it on the east beach. In June of 1994, the PFBC purchased another $5,000 \mathrm{yd}^{3}$.

During the spring of 1994, the PFBC dredged the marina basin, removing $6,000-10,000 \mathrm{yd}^{3}$ of logs, wood, leaves and organic muck. Much of this material was runoff from the nearby bluffs during the original project construction. The dredged material was to have been placed on the east beach, but it was unsuitable for beach fill because of the high organic content. It was instead placed on the back parking lot, allowed to dewater, and then given away to farmers.

In October of 1994, the PFBC purchased $50 \mathrm{~m}$ of beachfront property immediately west of the marina. This allowed state trucks and backhoes convenient access to the updrift fillet, and since November of 1994, the PFBC has bypassed material twice a year (Figure 24).

The bypassing procedure takes about 2 weeks to complete, depending on storms and other factors. In the first part of the operation, a backhoe piles sand 


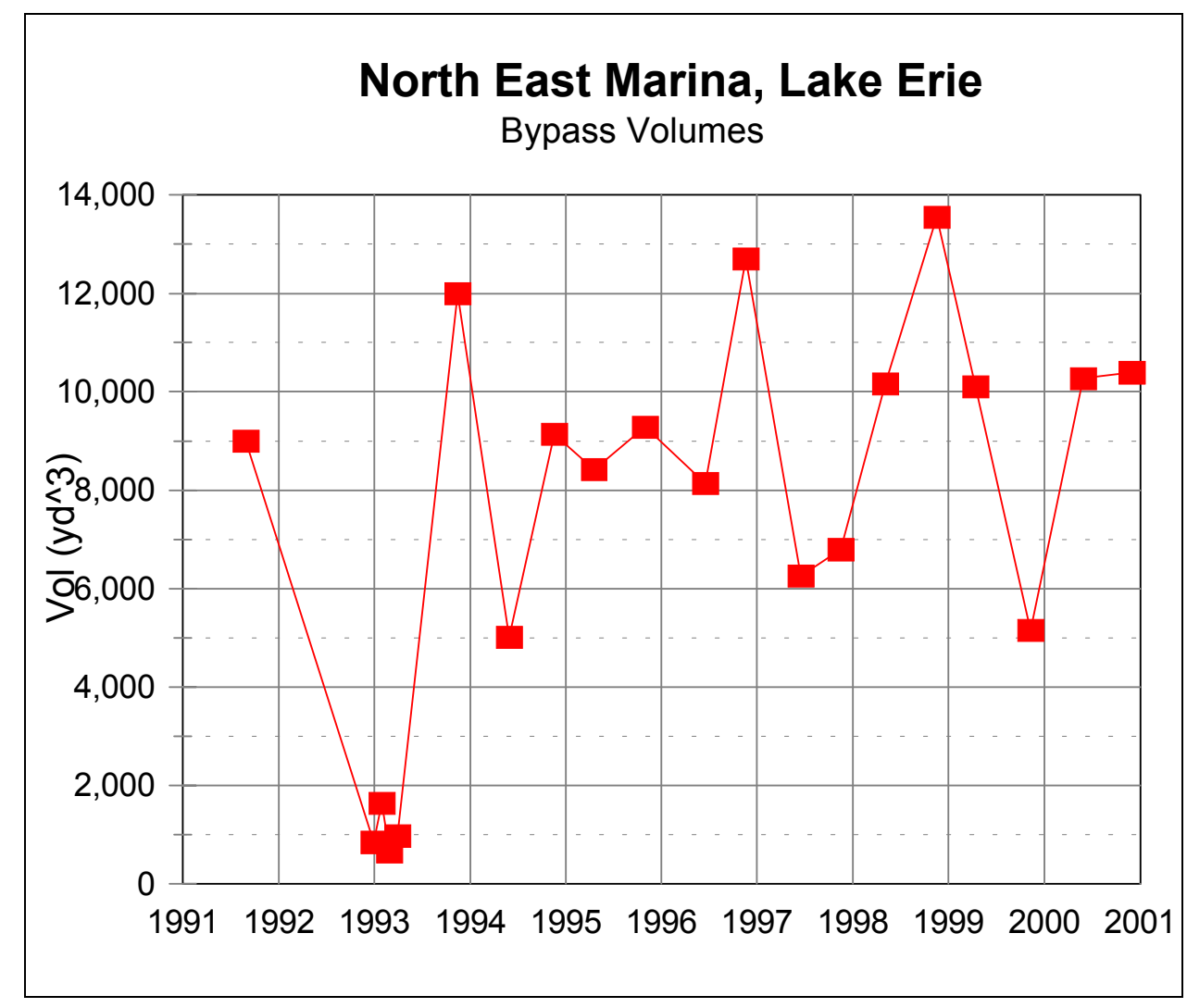

Figure 24. Bypassing at North East Marina. Cluster of points in early 1993 represent volumes moved during jet pump experiments (To convert cubic yards to cubic meters, multiply by 0.7645 )

and gravel from the west side fillet into a 5-m-high pile. To obtain as much material as possible from the fillet, the backhoe operator builds a temporary road out into the lake (Figures 25 and 26). Dump trucks are loaded with sand and gravel on the west side, cross the marina, back up along the beach, and deposit their loads. The initial loads are used to build a road at the base of the bluff so that the trucks can proceed east away from the sheltering effects of the marina walls, up to a distance of about $500 \mathrm{~m}$ from the east wall (Figure 27). Then sand is spread on the beach and into the water, pushed about by bulldozer. Depending on waves, the road is sometimes partly washed away at night and has to be rebuilt in the morning. During the early 1990s, when lake levels were higher, the road had to be built into the lake to go around the barrels that protrude from one lakefront property.

When lake level was high, probably all of the material that was bypassed by truck ended up in the littoral system, with the bulk being mobilized within a few weeks. Since the winter of 1998-99, with lower water level, some of the road has survived, so it has served to protect the base of the bluff. Therefore, this material has been temporarily removed from the littoral drift. Since November of 1993, PFBC has bypassed an annual average of $17,000 \mathrm{yd}^{3}$ of sediment at North East Marina (Table 4), almost twice the annual volume of fillet growth 


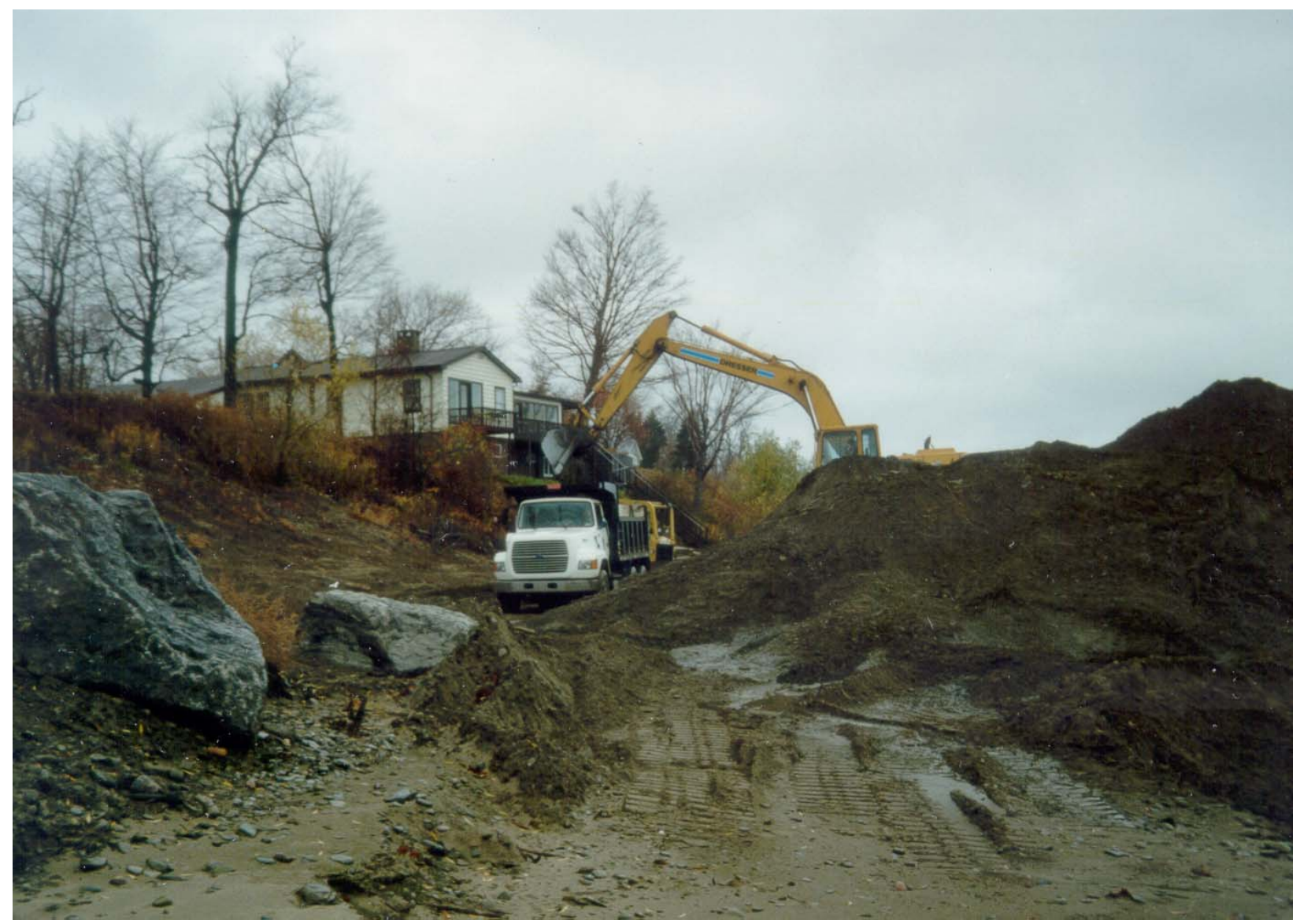

Figure 25. West fillet sediment being loaded into dump trucks, 17 November 1998

\begin{tabular}{|c|c|}
\hline \multicolumn{2}{|c|}{$\begin{array}{l}\text { Table } 4 \\
\text { Annual Volume Bypassed by PFBC at North East Marina }\end{array}$} \\
\hline Year & Volume $\left(\mathrm{yd}^{3}\right)^{2}$ \\
\hline $1993^{1}$ & 12,000 \\
\hline 1994 & 14,156 \\
\hline 1995 & 17,724 \\
\hline 1996 & 20,858 \\
\hline 1997 & 13,062 \\
\hline 1998 & 23,716 \\
\hline 1999 & 15,265 \\
\hline 2000 & 20,700 \\
\hline 1994-2000 total littoral bypassing: & 125,500 \\
\hline Average annual: & 17,180 \\
\hline \multicolumn{2}{|c|}{$\begin{array}{l}{ }^{1} \text { Material trucked to site from an upland sand source, not bypassed from the west side of the } \\
\text { marina to the east. } \\
{ }^{2} \text { To convert cubic yards to cubic meters, multiply by } 0.7645 \text {. } \\
\text { Source: Letter reports prepared by Pennsylvania Fish and Boat Commission (various dates) }\end{array}$} \\
\hline
\end{tabular}




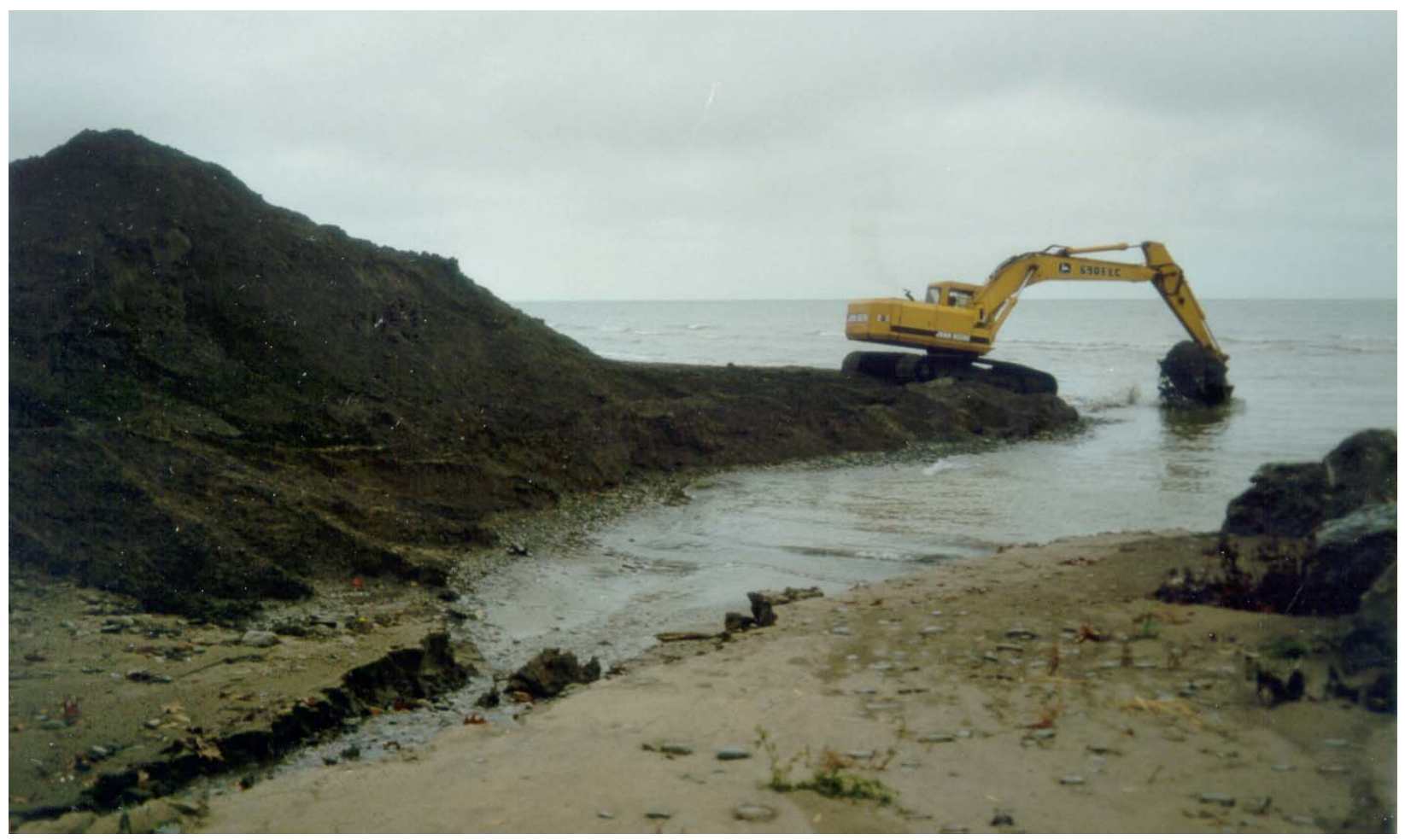

Figure 26. Backhoe removing sand and gravel from updrift fillet, 17 November 1998. A temporary road allows backhoe to proceed out into lake over $30 \mathrm{~m}$

reported by Taylor and Buyce (1994), who based their estimate on morphologic changes. The total amount of littoral material (excluding upland fill) bypassed from 1994 to 2000 was $125,500 \mathrm{yd}^{3}$.

The mouth of the marina has been cleared twice. The first time was in spring of 1994, when matted logs and sticks were removed. In April-May 1999, the mouth was again cleared. This time the debris was sandier than in 1994. Some sand may circle around the tip of the north wall and enter the entrance channel in the form of a spit, but the overall volume appears to be small because the bulk of material in the marina basin is organic, consisting of muck, leaves, sticks, and water plants (which provide food for the resident ducks and geese). 


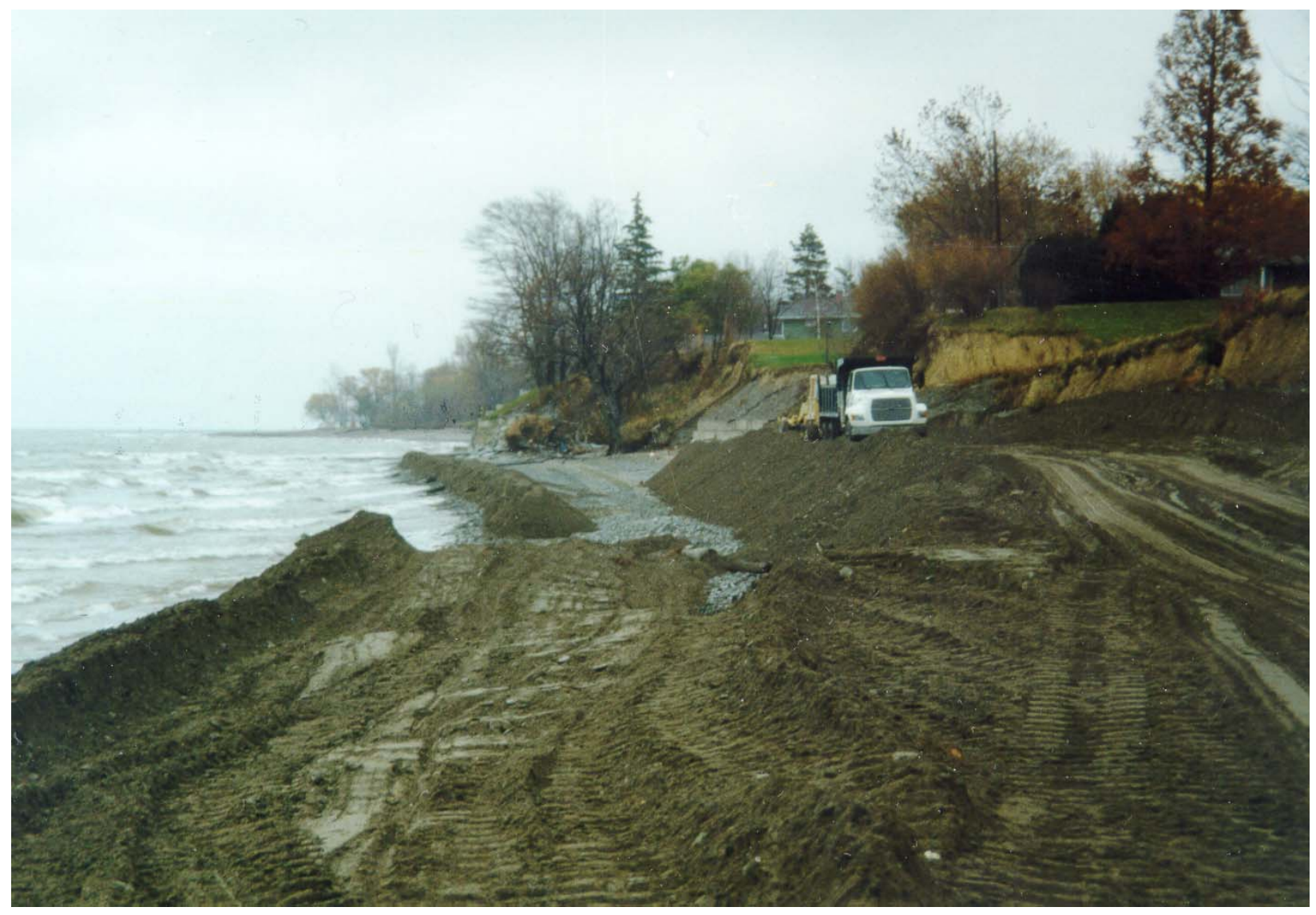

Figure 27. Temporary road along base of bluffs east of marina, 17 November 1998. Sediment is spread across beach and into water by a bulldozer 


\section{September 1999 Field Study}

\section{Side-Scan Sonar}

Side-scan sonar is a system of imaging underwater objects using highfrequency acoustic signals. Originally developed during World War II to detect enemy submarines, commercial systems designed for scientific use became available in the 1960s and since then have been extensively used by oceanographic institutions, universities, pipeline and marine construction companies, archaeologists, and treasure hunters. Side-scan sonar has become an invaluable tool to evaluate the condition of underwater structures and geologic features throughout the world, including the Great Lakes (e.g., Chrzastowski and Schlee (1988); Morang (1987); Clausner and Pope (1988)).

The basic side-scan system consists of the following three parts:

a. The transducers, mounted in a hydrodynamically streamlined body (towfish), towed at a depth below the turbulence of the survey vessels propeller wash.

b. A graphic chart recorder combined with a signal transmitter and processor.

c. A tow cable connecting the two units.

Most modern systems also include a digital data acquisition system to record the incoming signals and integrate them with navigation data, allowing additional signal processing at a later time to enhance the display of particular features.

Deployed a certain distance above the lake bed, the towfish emits a pulse of acoustic energy. This narrow pulse is transmitted at right angles to the tow direction and reflects from objects on the lake bed. Transducers in the towfish detect the reflections, convert them to electrical energy, and send them to the signal processing unit onboard the survey boat. Each returning signal is plotted on the paper a distance from the center line corresponding to the time it was received. The center line on the paper represents the towfishís trackline. Objects 
on the bottom which are close to the trackline are displayed near the center line, while objects located near the limit of the selected horizontal range are printed at the edges of the record. Objects directly underneath the towfish are normally not imaged because of the geometry of the sonarís beam pattern.

The recorded image is called a sonograph and is analogous to a continuous aerial photograph. It can give indications of the nature of the reflecting surface because the stronger the returning signal, the darker the corresponding mark on the paper. The intensity of the reflected signal is a function of material properties as well as of relief. Hard objects such as boulders and steel produce an intense reflection, whereas a flat, soft clay seafloor reflects very little signal. Belderson et al. (1972), Leenhardt (1974), and Morang, Larson, and Gorman (1997b) provide additional details on the use and theory behind side-scan sonar.

The Ohio Geological Survey (OGS), under contract to the Pittsburgh District, conducted side-scan sonar surveys at North East Marina on September 22, 1999. The OGS supplied a custom-equipped 8-m aluminum boat with the side-scan system and differential global positioning system (dgps) navigation (Table 5). The surveys were run during the late afternoon as the wind dropped and the seas calmed sufficiently to allow high-quality data collection. Four overlapping lines were run parallel to the shore at $100-\mathrm{m}$ and $75-\mathrm{m}$ horizontal range with the transducer frequency set at $500 \mathrm{kHz}$. The coverage extended from near the Pennsylvania-New York border in the east to about $2 \mathrm{~km}$ west of North East Marina (Figure 2). The OGS was unable to survey the nearshore closer than 10$20 \mathrm{~m}$ off the beach because of the presence of unmarked boulders that might have damaged the survey boat.

\begin{tabular}{|l|l||}
\hline \hline \multicolumn{2}{||l||}{\begin{tabular}{l||} 
Table $\mathbf{5}$ \\
Side-scan Sonar Specifications, 22 September 1999 Field Study
\end{tabular}} \\
\hline \hline Agency conducting survey & Ohio Geological Survey, Sandusky, OH (Dr. Scudder Mackey) \\
\hline \hline Linear coverage & $2.2 \mathrm{~km}$ \\
\hline Side-scan sonar system & Klein dual frequency model 595 \\
\hline Data acquisition system & $\begin{array}{l}\text { Triton ISIS (used to digitize side-scan data, record navigation data, } \\
\text { and perform georeferencing, signal enhancement, and mosaicing) }\end{array}$ \\
\hline Navigation & Trimble NT200D dgps \\
\hline
\end{tabular}

Examples of some of the side-scan sonar records are shown in Figures 28 and 29. Some findings are summarized below:

a. Sand in the active surf zone, even west of the marina, does not extend more than $20 \mathrm{~m}$ offshore. The most landward survey line, run at $100-\mathrm{m}$ range with the boat in about $2 \mathrm{~m}$ water depth, did not image the shoreface sand wedge at all. The bottom consisted of shale slabs, often with cracks and terraces. Numerous boulders rest on the shale. Some of these boulders rise close to the lake surface and pose a definite hazard to boats. 


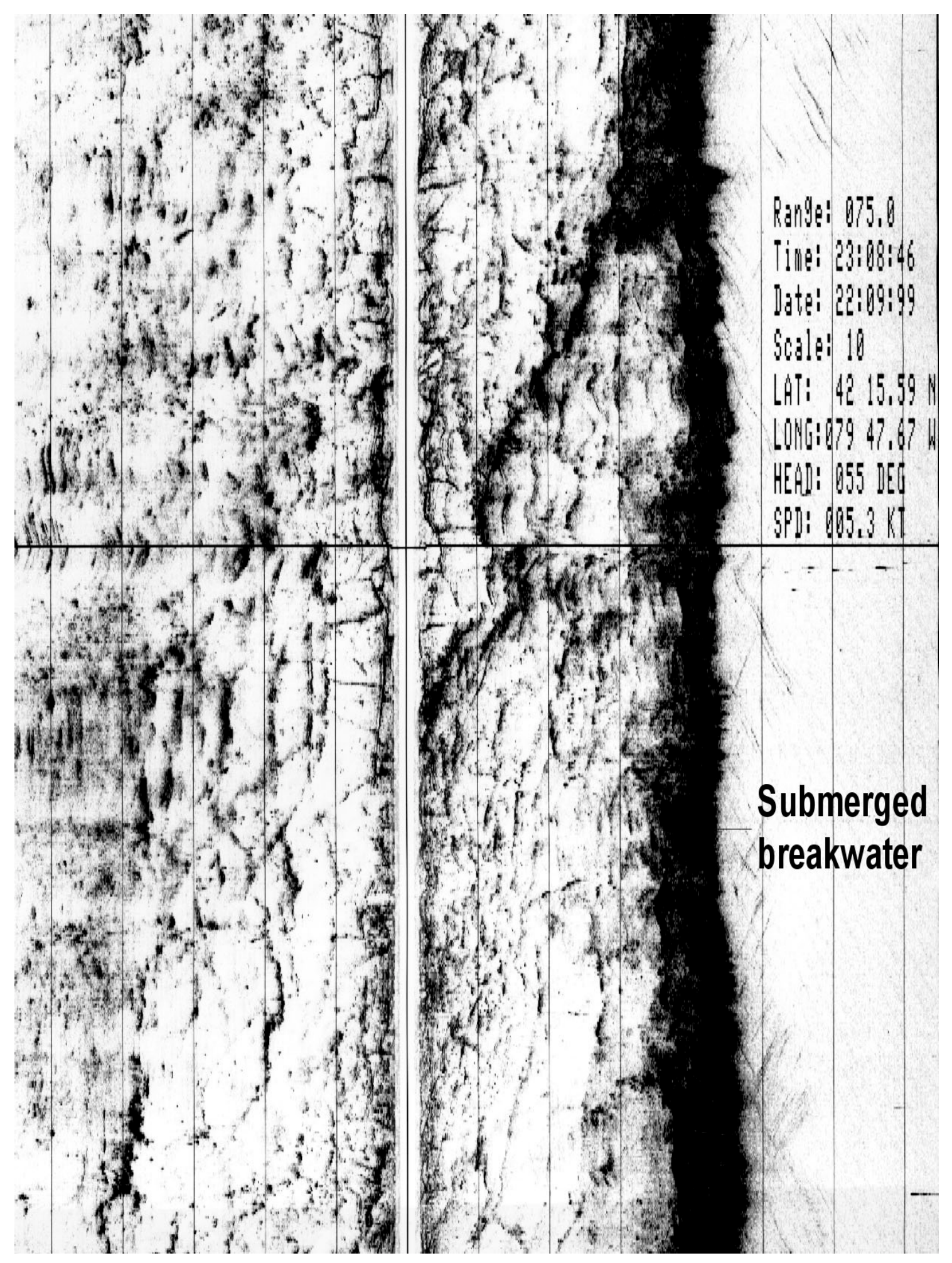

Figure 28. Sonograph immediately off marina wall, approximately halfway between east and west corners. Ship was heading NE paralleling wall. Scale between vertical lines is $10 \mathrm{~m}$, and northeast is to top of page. Dark area to right is highly-reflective submerged portion of breakwater. Bedrock jointing and bedding and lack of sand is clearly shown on record 


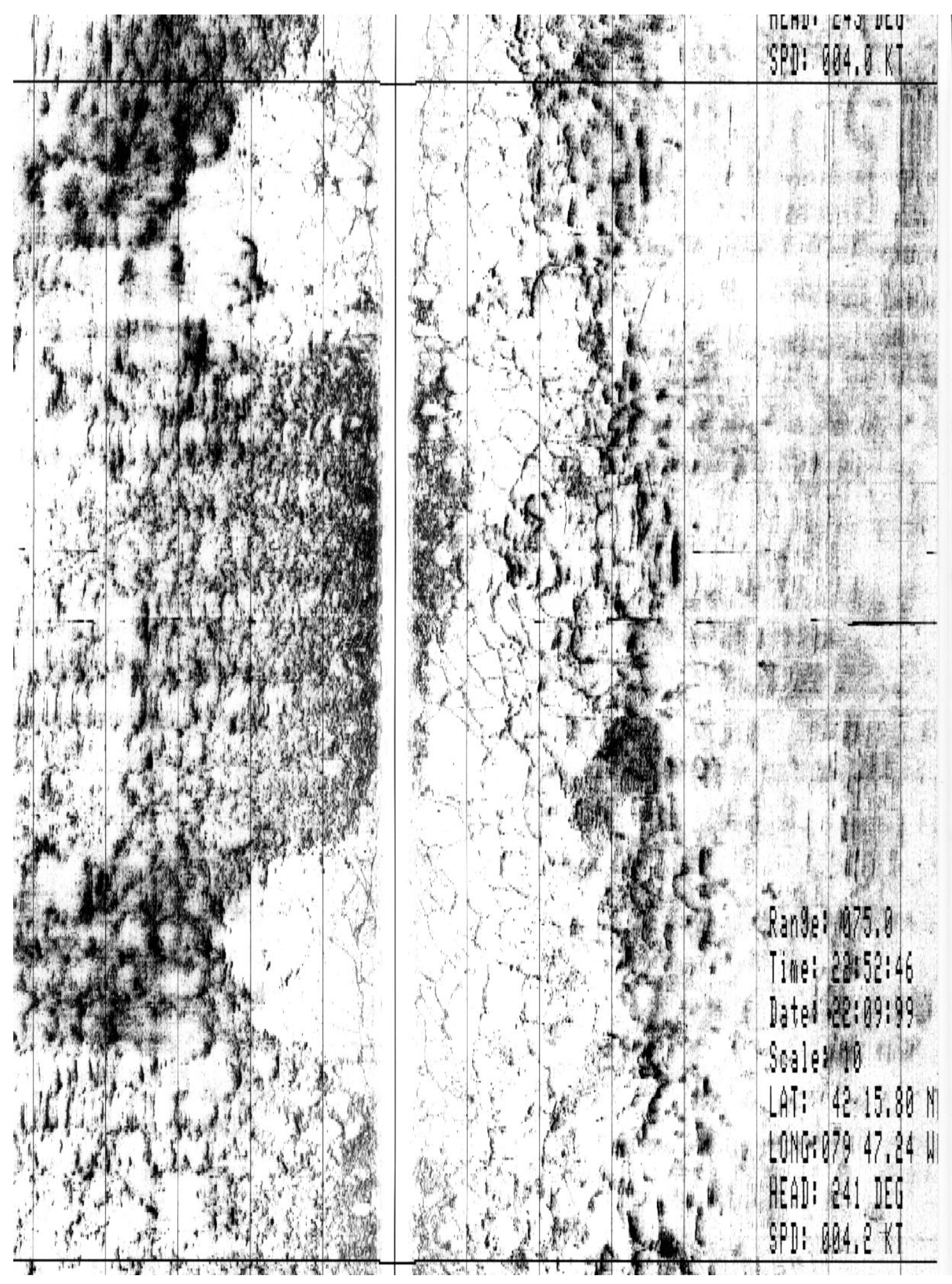

Figure 29. Sonograph, SW of the marina wall, shows additional bedrock jointing and bedding exposed on lake bed, with no evidence of sand. Ship heading was SW and distance from shore was approximately $250 \mathrm{~m}$ 
b. Some rippled patches of sand were imaged in about 10-m water depth on the two seaward survey lines. The patches were intermittent and displayed varying reflectivity on the sonographs. The lightest color consisted of very fine sand, almost silt. The darker material was coarse sand with a large percentage of lithic fragments. The very dark material consisted of zebra mussel shell hash. Samples were collected with a hand-operated grab sampler.

c. Off the marina wall and west of the marina, the bottom consisted of shale slabs with fractures and some rubble. No sand could be seen in the sonographs made off the north rubble wall of the marina (Figure 29).

d. The largest accumulation of sand was detected in about 8-m water depth off Twentymile Creek, east and downdrift of the marina. This sand was composed mostly of coarse lithic fragments. Similar sand was sampled about $100 \mathrm{~m}$ up the river on a point bar, suggesting that the river is the source of this offshore sand lens.

\section{Diver, Video, and Visual Observation}

On 19 October, 1999, four members of the Buffalo District dive team traveled to North East Marina to make underwater observations, take samples, measure sediment depths, and videotape underwater conditions in the vicinity of the marina for the purpose of mapping the presence and extent of littoral sediments. South 10 to $15 \mathrm{mph}$ winds produced a calm lake, and a lack of precipitation during the preceding days resulted in very clear water with 3- to 5-m visibility. The thickness of beach sediments was measured at the waterís edge at three locations on the west side of the marina (sta W $0+75$, W 2+25, W 8+00) and three locations on the east side (sta E7+50, sta E9+00, sta E 11+00). These measurements were taken by pushing or pounding a three-fourths in. diameter steel probing rod into the sediments until refusal. Refusal was generally assumed to be shale bedrock (opposed to some other obstacle) based on the reaction/sound of the probe rod and the depth that was achieved. The team made the visual observations and collected video by wading, diving, and working from the pontoon boat.

Because of the shallow water, the lack of sediments offshore, and the clarity of the water, after using divers to make visual observations along two lines, the team concluded that there was little benefit gained by the higher risk and more timeconsuming use of observers in the water. The remaining data was therefore collected from the surface, which allowed the work to proceed much more quickly and efficiently. Video coverage was obtained by hanging the camera from the deck of the boat and moving the boat along the transect lines. The observations are summarized in Table 6 and the complete field notes reproduced in Appendix D.

In summary, the visual observations confirmed that sand is restricted to the fillet area on the west side of the marina and to a narrow band along the beach on 


\begin{tabular}{|c|c|c|c|}
\hline \multicolumn{4}{|c|}{$\begin{array}{l}\text { Table } 6 \\
\text { Summary of Visual Observations }\end{array}$} \\
\hline Profile ${ }^{1}$ & $\begin{array}{l}\text { Sand Thickness } \\
\text { Above Bedrock (m) }\end{array}$ & $\begin{array}{l}\text { Water Edge Dist. } \\
\text { from sta }(\mathrm{m})\end{array}$ & Notes $^{2}$ \\
\hline W $0+75$ & $0.8-1.0$ near shore & 49 & $\begin{array}{l}\text { Med-fine sand above bedrock, } \\
\text { rippled surface. } 150 \text { m from water's } \\
\text { edge (WE), no sand, cobble bottom. } \\
\text { Cobble in deeper water algae- } \\
\text { covered, indicating infrequent or no } \\
\text { sand burial. }\end{array}$ \\
\hline W 2+25 & 1.0-1.2 near shore & 37 & $\begin{array}{l}120 \mathrm{~m} \text { from WE, cobble/boulder } \\
\text { bottom without sand. }\end{array}$ \\
\hline W $8+00$ & 0.5 near shore & 18 & $\begin{array}{l}60 \mathrm{~m} \text { from WE, hard shale bottom, } \\
\text { boulders, some sand pockets. }\end{array}$ \\
\hline $\begin{array}{l}\text { Marina } \\
\text { wall, } 30 \mathrm{~m} \\
\text { east of } \\
\text { west corner }\end{array}$ & & & $\begin{array}{l}\text { Cobble bottom at base of armor } \\
\text { stone for } 7.5 \mathrm{~m} \text { (broken, irregular } \\
\text { pieces near wall, rounded rock } \\
\text { pavement further offshore), thereafter } \\
\text { thin veneer of sand ripples for next } \\
7.5 \mathrm{~m} \text {. Clean hard shale beyond. }\end{array}$ \\
\hline $\begin{array}{l}\text { Marina } \\
\text { wall, } 30 \mathrm{~m} \\
\text { west of } \\
\text { east corner }\end{array}$ & & & $\begin{array}{l}\text { Cobble bottom at base of armor } \\
\text { stone for } 7.5 \mathrm{~m} \text {, then only a trace of } \\
\text { sand for the } 7.5 \mathrm{~m} \text {. Clean hard shale } \\
\text { beyond with no evidence of sand. }\end{array}$ \\
\hline $\begin{array}{l}\text { Approx one } \\
\text { half } \mathrm{mi} \\
\text { west of } \\
\text { marina }\end{array}$ & & & $\begin{array}{l}\text { Scattered cobbles with limited sand } \\
\text { on hard shale bottom from WE to } 30 \\
\mathrm{~m} \text { offshore. Clean shale bottom } 30 \text { - } \\
180 \mathrm{~m} \text { from shore. }\end{array}$ \\
\hline$E 7+50$ & 0.3 & 28 & $\begin{array}{l}10-15 \mathrm{~cm} \text { cobble between } 75-90 \mathrm{~m} \\
\text { from WE. } 0.5 \mathrm{~m} \text { thickness of sand } \\
\text { over shale bottom at south side of } \\
\text { entrance channel. At } 7 \mathrm{~m} \text { from east } \\
\text { end of outer breakwater, cobble shoal } \\
\text { then bare rock with minor amounts of } \\
\text { sand in cracks. }\end{array}$ \\
\hline$E 9+00$ & 0.3 & 11 & Hard shale bottom $60 \mathrm{~m}$ from WE \\
\hline E $11+00$ & 0.15 & 3 & $\begin{array}{l}\text { Minimal sand cover. Hard shale } \\
\text { bottom } \approx 30 \mathrm{~m} \text { from WE }\end{array}$ \\
\hline
\end{tabular}

the east (downdrift) side. Once the edge of the sand is reached, the bottom consists of cobble or bare shale with only minor amounts of sand and cobble in cracks. Lakeward of the marinaís outer wall, the bottom is cobble and shale with a minimal veneer of rippled sand. A band of course cobble found at the landward edge of the entrance channel appears to be bedding or "chinking" stone from the original marina construction. The PFBC has reported that bedding stone has been lost over time from the riprap along the lakeward wall, causing the riprap to settle. 


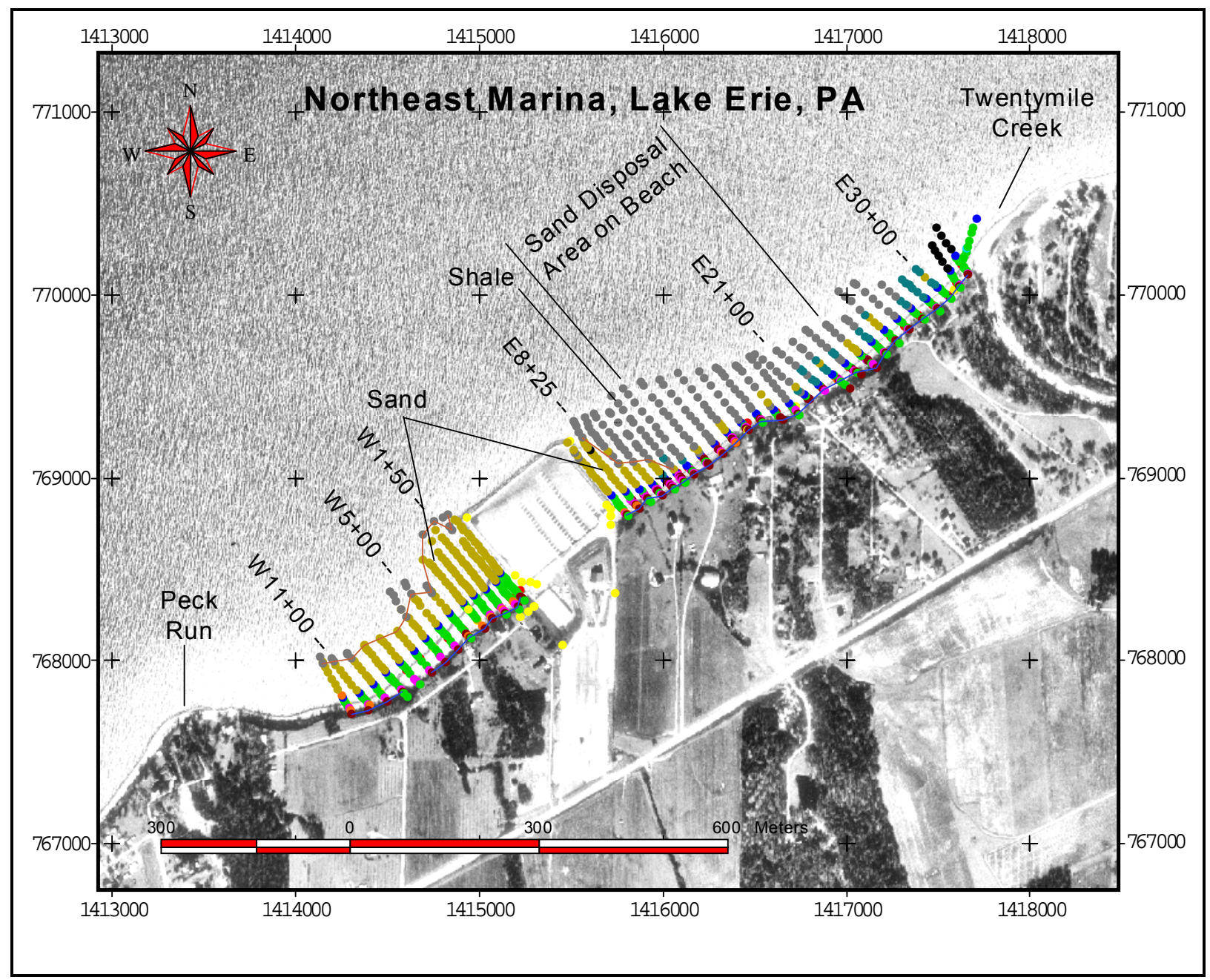

Figure 30. September 1999 profiles. State plane coordinate system, Pennsylvania North Zone, NAD 83, units in feet. Photograph is USGS digital ortho quarter quadrangle, converted from UTM coordinates to PA state plane (To convert feet to meters, multiply by 0.3048 )

\section{Profile Surveys}

Cross-shore profiles are a common form of topographic data used by coastal scientists to evaluate beach and nearshore morphology changes over time (Gorman, Morang, and Larson 1998; Morang, Mossa, and Larson 1993; Grosskopf and Kraus 1994). Profiles surveyed over time provide a convenient visual means to determine if the shoreline is advancing or retreating or if the beach is gaining or losing sediment.

At North East Marina, Benchmark Surveying of Waterford, PA, collected short shore-perpendicular profiles in 1990 (see Appendix C for an inventory). The 1990 profiles, spaced $23 \mathrm{~m}$ (75 ft) apart, ran perpendicular from a baseline established on the beach into the water as far offshore as the sand/rock junction (typically only $0.5 \mathrm{~m}$ below the water surface). The 1991 and 1992 profiles were 
longer, extending as far as $180 \mathrm{~m}$ offshore. We recovered these data from data sheets and memoranda provided by the PFBC and the Buffalo District and digitized and plotted the values (Appendix C). Topographic data was also collected by TBS Consulting in 1994 (Taylor and Buyce 1994). TBS did not use the same baseline as Benchmark, and the digital data, collected with a Leitz total station, are now unavailable due to the death of the principal data analyst and loss of records.

One of the goals of the 1999 field study was to reoccupy the old survey lines to accomplish the following:

a. Determine sand accumulations and changes in bottom configuration since 1992.

b. Delineate interface between sandy and rock bottom.

c. Measure bluff location and slope and use these data to augment offshore Light Detection and Ranging (LIDAR) surveys (aircraft-borne laser topography surveys).

GRW Aerial Surveys, under contract to the Pittsburgh District, re-established the 1991 baseline by using the original rebar pins set by Benchmark Surveying on Sightsinger Road (see Appendix D). GRW occupied the original lines at $23 \mathrm{~m}$ spacing and added new lines at $30 \mathrm{~m}$-spacing as far east as Twentymile Creek. Horizontal control for these profiles was referenced to the North American Datum (NAD) 1983 Pennsylvania State Plane north zone grid, in units of U.S. survey feet (see Appendix D for details). Vertical control was referenced to the IGLD 85 (Coordinating Committee 1992). The surveyors used conventional land surveying methods. A total station was placed directly over the monument on the beach and a rod man walked across the beach, placing the rod at each change in morphology or slope. Wearing a divers drysuit, he proceeded out into the water, stopping at frequent intervals for elevation measurements. Near the marina, the profiles were about $200 \mathrm{~m}$ long, while further away, the profiles extended far enough offshore to reach the sand/rock boundary (Figure 30 ). 


\section{Analysis of Profile Data}

\section{Procedure Used to Compute Profile Volumes}

\section{Overview}

Sand volumes for each profile were computed with the Beach Morphology Analysis Package (BMAP) software (Sommerfeld et al. 1994). Profile volume is defined as the area under the profile curve times a one-foot unit width of the beach (i.e., $\mathrm{yd}^{3} / \mathrm{ft}$ ). These data were exported to a Quattro Pro spreadsheet for tabulating and further analysis.

We used a four-stage procedure to compute the sand volumes for the four available survey data sets at North East Marina. The procedures are as follows:

a. Compute total sand at each profile for the 5-30-90 preproject survey (units $\left.\mathrm{yd}^{3} / \mathrm{ft}\right)$.

$b$. Measure differences in volume between 5-30-90 and each of the three subsequent surveys (units $\mathrm{yd}^{3} / \mathrm{ft}$ ).

c. Compute total sand under the curve at each profile (units $\mathrm{yd}^{3} / \mathrm{ft}$ ).

d. Multiply profile volumes by linear distance along the beach to obtain total sand volume on the beach and nearshore zone, from the base of the bluff to the offshore limit of sand (units $\mathrm{yd}^{3}$ ).

\section{Description}

Computing the volumetric difference between two surveys is a simple procedure using the BMAP software. The area below the profile curve and above some arbitrary horizontal line is subtracted from the area below a second curve and that same baseline. The actual depth of this arbitrary base level is unimportant because we are only concerned with the difference between the two survey dates - the area that overlaps is subtracted in the mathematics (Figure 31). 


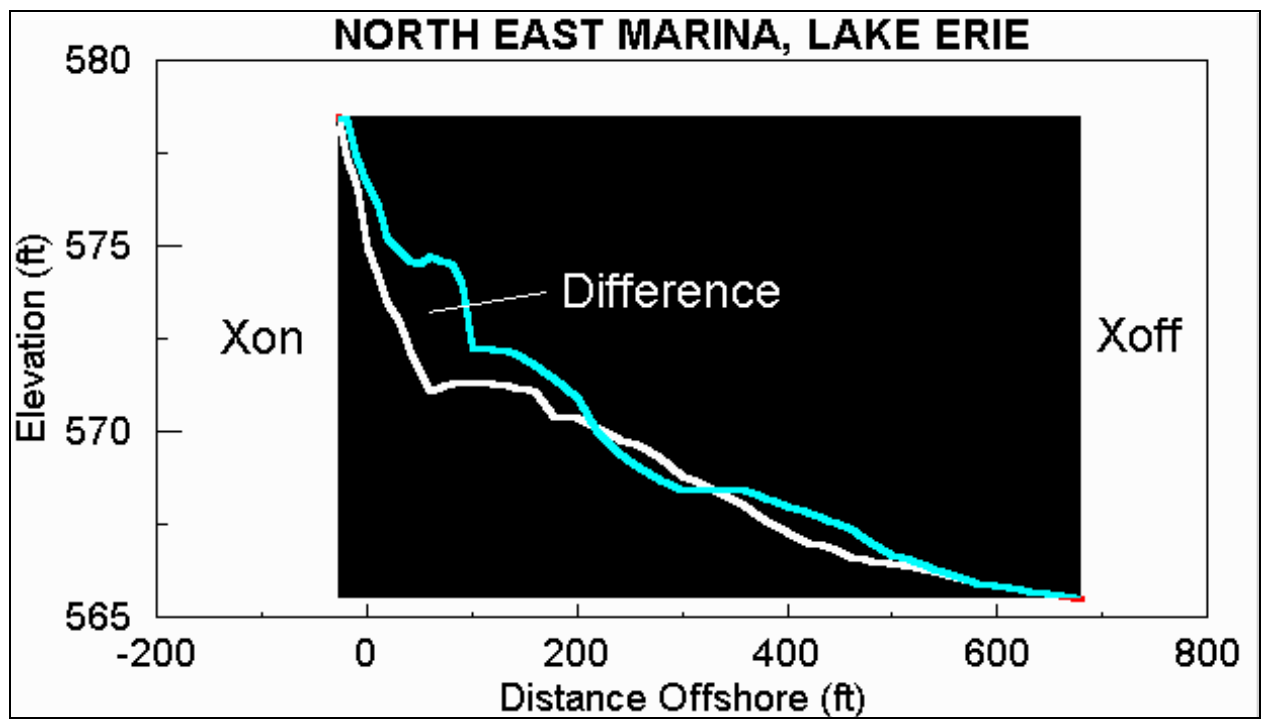

Figure 31. Determination of volumetric difference between two profiles (To convert feet to meters, multiply by 0.3048 )

Determining the total sand volume on a beach requires an extra step: the analyst must specify the base level that will be defined as the beach (Figure 32). This may be the low tide line, the base of the trough, or some other morphologic feature, or it may be an arbitrary depth such as $-30 \mathrm{ft}^{1}$ that can be applied uniformly to all the profiles along the beach. The analyst normally assumes that all the material under the profile is sand, a valid assumption for many East and Gulf coast settings, but not necessarily appropriate to the geologically complex shores of the Great Lakes.

However, computing beach volume above hard bottom, such as the bedrock at the North East study site, is more complicated. Along the Pennsylvania shore of Lake Erie, shale slopes up towards land as a series of steps or terraces, and the beach consists of a veneer of sand and gravel resting on the bedrock platform. Therefore, using a uniform horizontal base for the volume computations, as in Figure 32, might include rock in the measured volume. The BMAP software does not allow the user to specify a sloping base for the volume computations. Therefore, a multistage procedure to compute sand volumes for the North East profiles was used and includes the following.

a. A volume was computed for the 5-30-90 preproject profiles.

Assumption 1: In this case, a horizontal base was assumed because topographic data about the rock-sand interface was unavailable. This elevation was based on annotations on the survey data sheets.

1 All elevation (el) cited herein are in feet, referenced to the International Great Lakes Datum of 1985 (IGLD 85) (to convert feet to meters, multiply by 0.3048 ). 


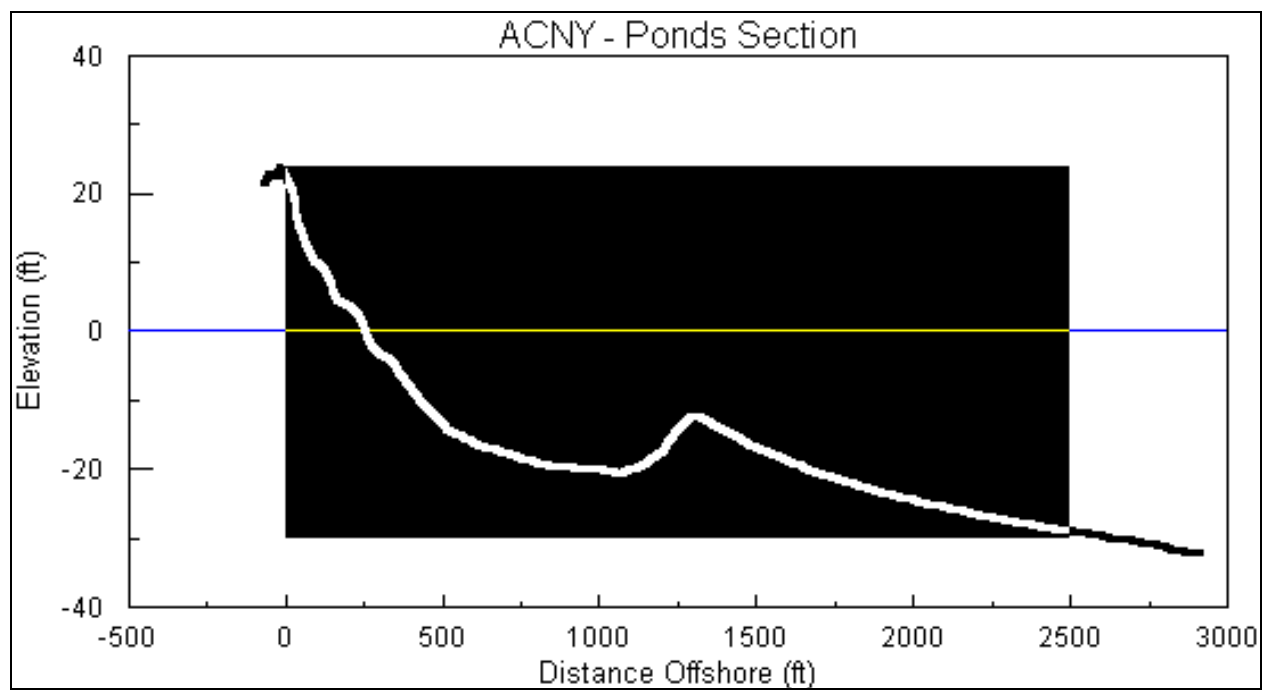

Figure 32. Example of profile from sandy environment. In this example, from Southampton, Long Island, NY, an elevation of $-30 \mathrm{ft}$ was selected for computing sand volume, under the assumption that geology here was entirely sand

Assumption 2: For the profiles west of the marina, the survey points did not extend back to the base of the bluff. Therefore, to compute volumes for the entire beach, we extended the profiles landward at the same angle as the slope of the first two points on the profile. The sand in the triangle under the new, extended profile was defined to be the initial, preproject sand volume (Figure 33).

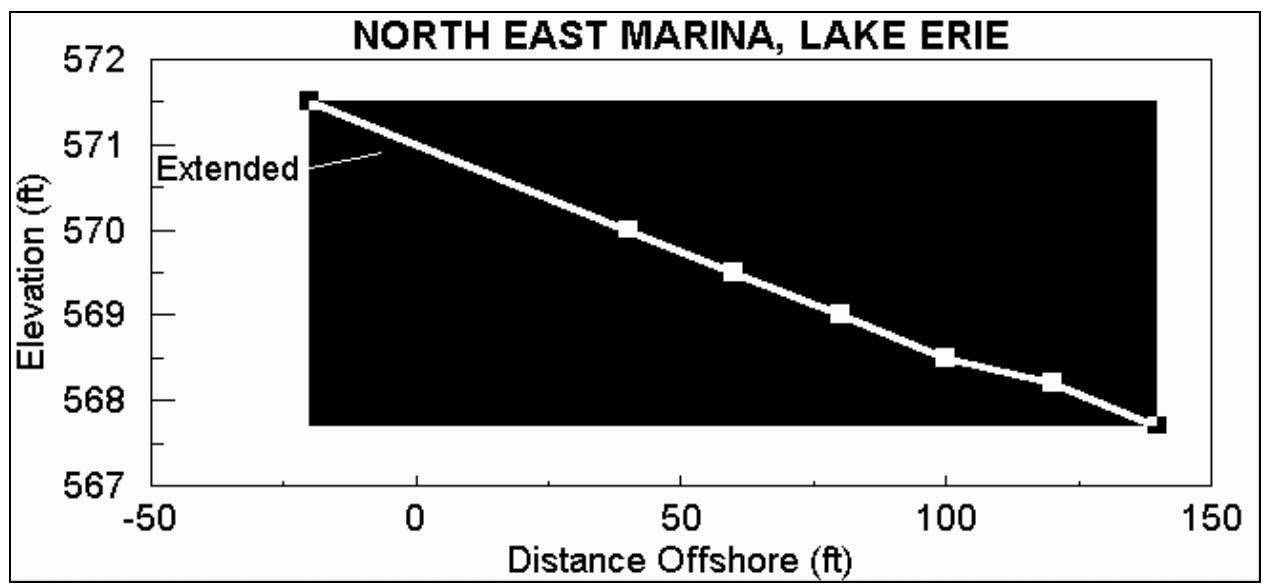

Figure 33. Computation of sand volume for 5-30-90 preproject profile W150. Here, first original data point was at el 50 . Therefore, to evaluate approximate total volume of sand for preproject condition, profile has been artificially extended back to el -20 using same slope as first two original data points 
Assumption 3: The 5-30-90 survey lines only extended to the limit of sand at that time, and we do not have survey data describing the topography of the bare shale lake bed. Therefore, to compute how much sand has accumulated on this now-buried shale surface, the lakeward limit of the 5-30-90 surveys had to be extended out to the point where the sand/shale interface occurred on the later surveys (Figure 34). This straight line approximately follows the slope of the shale surface, although we know that the true surface consists of terraces, cracks, and lumps.

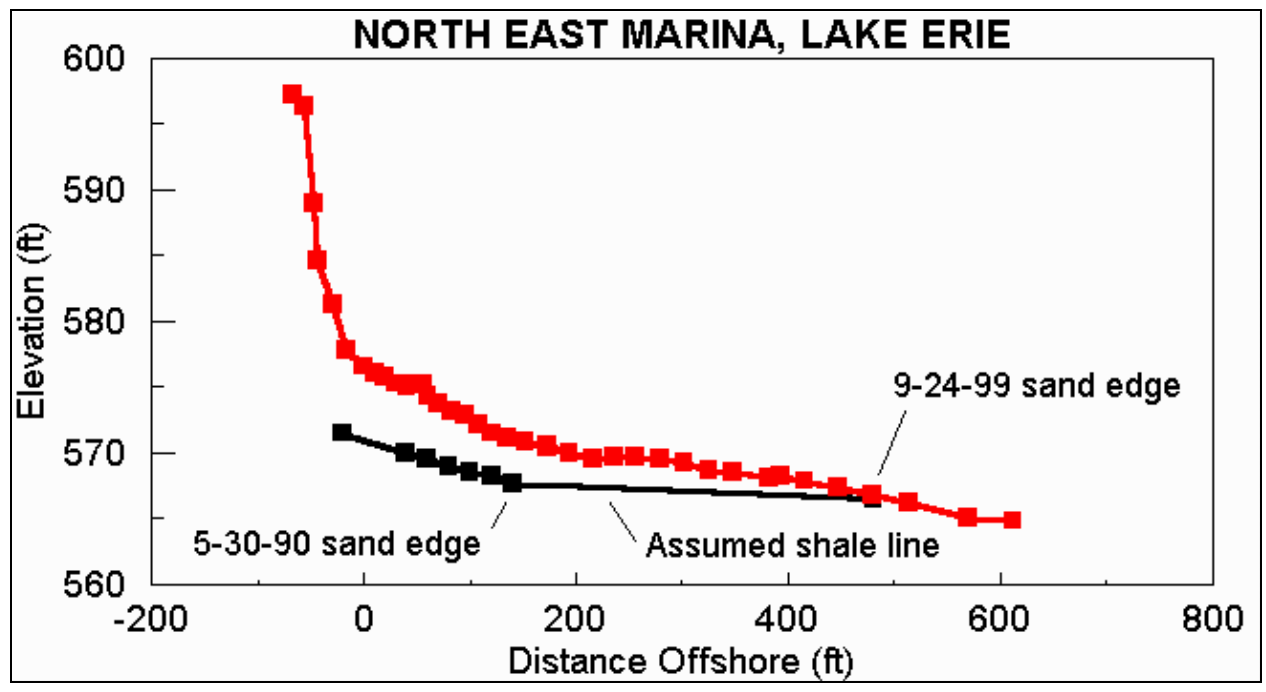

Figure 34. Extension of 5-30-90 from original shale line to location of shale line on 9-24-99 profile. This sloping line approximates shale lake bed, now covered with sand

$b$. For computing the difference between subsequent surveys, the volume below the profile for each date was measured above an el 560 (selected arbitrarily to be deeper than the deepest profile) and between two horizontal limits, $\mathrm{X}_{\text {on }}$ and $\mathrm{X}_{\text {off }}$ (Figure 35).

c. The difference in volume under the curve between 5-30-90 and subsequent surveys was computed by:

$$
\text { Difference }=\left(\text { Vol }_{\text {Date2 }} 560 f t-V_{0} l_{5-30-90560 f t}\right)
$$

d. The total sand volume for the 12-4-91, 9-16-92, and 9-24-99 surveys was computed by adding the 5-30-90 (preproject) volume (Step 1) to the difference computed in Step 3:

$$
\text { Tot Vol }=\text { Vol }_{5-30-90}+\text { Difference }
$$




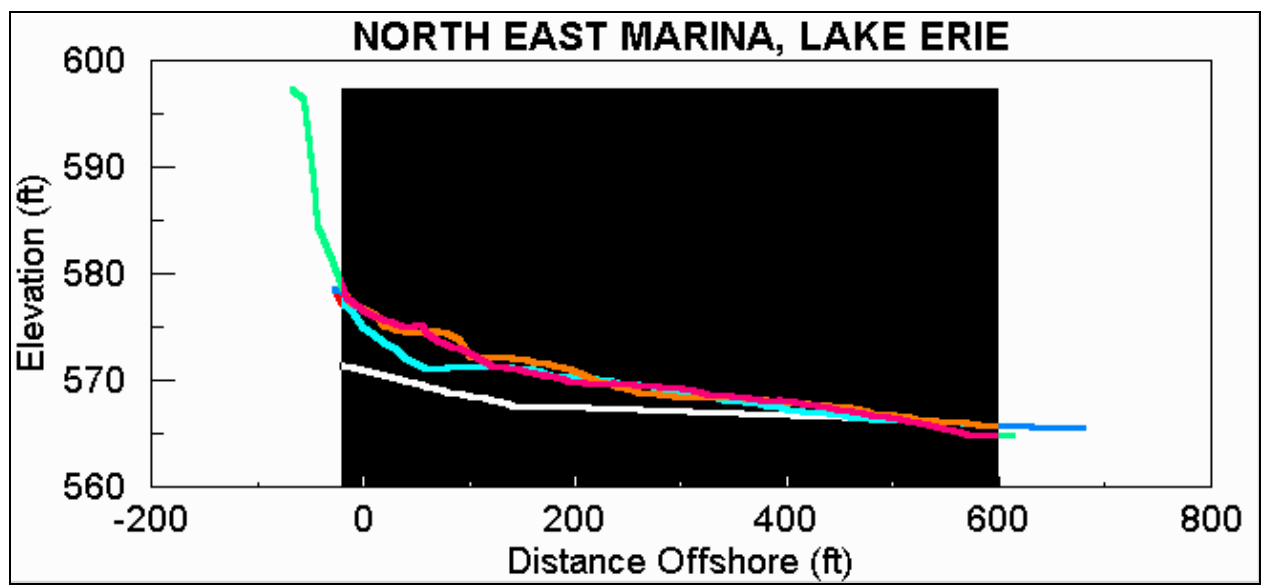

Figure 35. Volume measurement for $\mathrm{W} 150$ profiles. In this example, $\mathrm{X}_{\mathrm{on}}$ is el -20 (base of bluff), $X_{\text {off }}$ is el +600 , and volumes are computed above el 560 (chosen arbitrarily to be below deepest profile)

\section{Limits used for volume computations}

Initial landward position, $X_{o n}$ : Base of bluff. This varied from el -20 to el -68 from the survey monument (i.e., in an onshore direction).

Lakeward position, $X_{\text {off }}$ : This was selected to be el 600 for the fillet area west of the marina, lines W025 to W300. Further west than line W300 and east of the marina, $X_{\text {off }}$ was the position of the sand-rock interface as noted on the 9-24-99 survey logs. Table 7 lists details of the 5-30-90 profile limits and the $X_{\text {on }}$ and $X_{\text {off }}$ limits used for computations.

Volumes at W400, W500, and W600: No preproject profile were collected at W400, W500, and W600. Therefore, preproject profile W300 was used at these three locations with the assumption that the beach in this area was reasonably uniform over an east-west reach of el 400 .

Volumes at E1050 and E1125: No preproject profile was available at E1125. It was not reasonable to project the 1990 E1050 profile to E1125 because the monument was a different distance from the bluff base, and we did not consider it valid to arbitrarily move the E1050 profile back or forth to attempt to match the other E1125 surveys.

\section{Results - Profile Volumes Based on Topographic Surveys}

Table 8 lists sand volumes for profiles W600 to E1125 and the computation limits. These values are in terms of the sand volume in a strip one foot wide $\left(\mathrm{yd}^{3} / \mathrm{ft}\right)$. To obtain the total volume of sand on the beach, each profile volume was multiplied by a distance factor that consisted of the sum of the half-distance to the adjacent profiles (left and right): 


\begin{tabular}{|c|c|c|c|c|c|c|}
\hline \multicolumn{7}{|c|}{$\begin{array}{l}\text { Table } 7 \\
\text { Profile Volumes }\end{array}$} \\
\hline \multirow[b]{2}{*}{ Profile } & \multicolumn{4}{|c|}{ Sand Volume ( $\left.\mathrm{yd}^{3} / \mathrm{ft}\right)$} & \multicolumn{2}{|c|}{ Computation limits (ft) } \\
\hline & $\begin{array}{c}\text { 30-May- } \\
1990\end{array}$ & 4-Dec-1991 & $\begin{array}{l}\text { 16-Sep- } \\
1992\end{array}$ & $\begin{array}{c}\text { 24-Sep- } \\
1999\end{array}$ & $\begin{array}{c}\mathrm{X}_{\text {on }} \\
\text { (base of } \\
\text { bluff) }\end{array}$ & $x_{\text {off }}$ \\
\hline W600 & $30.4^{1}$ & & & 61.4 & -68 & 236 \\
\hline W500 & $24.7^{1}$ & & & 68.9 & -50 & 330 \\
\hline W400 & $18.7^{1}$ & & & 69.5 & -28 & 280 \\
\hline W300 & 12.2 & 32.0 & 38.4 & 52.1 & 0 & 600 \\
\hline W225 & 13.7 & 44.5 & 56.6 & 54.3 & -20 & 600 \\
\hline W150 & 10.9 & 48.0 & 63.5 & 58.6 & -20 & 600 \\
\hline W075 & 15.0 & 83.4 & 94.6 & 85.9 & -20 & 600 \\
\hline W025 & 11.9 & 74.0 & 89.4 & 78.9 & -20 & 600 \\
\hline E750 & 15.9 & 24.6 & 16.5 & 47.6 & -20 & 350 \\
\hline E825 & 11.2 & 18.4 & 15.6 & 41.0 & -20 & 370 \\
\hline E900 & 7.6 & 7.6 & 6.0 & 18.9 & -20 & 220 \\
\hline E975 & 6.7 & 4.2 & 2.5 & 10.0 & -30 & 200 \\
\hline $\mathrm{E} 1050^{2}$ & 7.2 & 5.1 & 3.1 & 3.6 & -20 & 35 \\
\hline $\mathrm{E} 1125^{2}$ & & 5.5 & 3.8 & 3.9 & -20 & 40 \\
\hline
\end{tabular}

$$
\text { Dist } \text { Total }=1 / 2 \text { Distleft }+1 / 2 \text { Dist } \text { right }_{\text {t }}
$$

The results are easier to visualize as graphs. Figure 36 shows the volume changes over time for the west profiles. At all locations, volume increased rapidly between 5-30-90 and 9-16-92, during the period of marina construction, especially at lines W025 and W075. These data confirm the visual observations that a large fillet grew on the west side of the marina wall. The recent survey, 924-99, shows that the volumes of most of the west lines have stabilized or even slightly decreased. The period of stable overall volume coincides with the years that the PFBC has been bypassing sand from the west to the east side of the project. Only at line W300 did the volume increase from 1992 to 1999, and this is accounted for by the accumulation of sand on the upper part of the beach (see Appendix C). This is private property, west of the area where the PFBC mines the beach during its spring and fall bypassing operations.

East of the marina, beach volume decreases towards the east (Figure 37). At the two lines closest to the east wall, E750 and E825, volume has more than doubled since 1992. Overall elevation has increased 0.3-0.6 $\mathrm{m}$ across the entire 


\begin{tabular}{|c|c|c|c|c|c|}
\hline \multicolumn{6}{|c|}{$\begin{array}{l}\text { Table } 8 \\
\text { Total Sand Volume }\end{array}$} \\
\hline \multirow[b]{2}{*}{ Profile } & \multirow[b]{2}{*}{$\begin{array}{c}\text { Distance } \\
\text { multiplier (ft) }\end{array}$} & \multicolumn{4}{|c|}{ Regional volume $\left(\mathrm{yd}^{3}\right)$} \\
\hline & & 30-May-1990 & 4-Dec-1991 & 16-Sep-1992 & 24-Sep-1999 \\
\hline W600 & 100 & $3,037^{1}$ & & & 6,136 \\
\hline W500 & 100 & $2,474^{1}$ & & & 6,895 \\
\hline W400 & 100 & $1,867^{1}$ & & & 6,954 \\
\hline W300 & 87.5 & 1,071 & 2,803 & 3,362 & 4,556 \\
\hline W225 & 75 & 1,029 & 3,339 & 4,241 & 4,070 \\
\hline W150 & 75 & 817 & 3,598 & 4,760 & 4,391 \\
\hline W075 & 62.5 & 938 & 5,210 & 5,915 & 5,367 \\
\hline W025 & 25 & 296 & 1,851 & 2,236 & 1,973 \\
\hline \multicolumn{2}{|c|}{ W. vol (W025-W300): } & 4,151 & 16,801 & 20,514 & 20,358 \\
\hline \multicolumn{2}{|c|}{ W. vol (W025-W600): } & $11,530^{1}$ & & & 40,343 \\
\hline E750 & 75 & 1,190 & 1,846 & 1,240 & 3,568 \\
\hline E825 & 75 & 838 & 1,381 & 1,170 & 3,073 \\
\hline E900 & 75 & 572 & 572 & 451 & 1,421 \\
\hline E975 & 75 & 501 & 312 & 190 & 748 \\
\hline E1050 & 75 & 543 & 383 & 230 & 272 \\
\hline E1125 & 75 & & 409 & 286 & 294 \\
\hline \multicolumn{2}{|c|}{ E. vol (E750-E1125): } & 3,644 & 4,902 & 3,567 & 9,377 \\
\hline
\end{tabular}

beach, from the bluff toe to about $130 \mathrm{~m}$ offshore. Directly in front of the bluff, part of the 1998 fill remains as a raised terrace. Thanks to a mild winter storm season and dropping lake levels, the trucked fill was not completely removed as it had in previous winters. Profiles E900 and E975 also show volume increase, but to a lesser extent than the two lines closer to the marina. Profiles E1050 and E1125 were stable volume over time. These indicate that E1050 is about the easternmost limit where the influence of the marina can be detected with respect to sediment accumulation (or loss) on the beach.

Figure 38 summarizes total volume change over time for the east and the west beaches. The west beach volume between W025 and W300 is almost identical to the 1992 volume, while the east beach has almost doubled. These data indicate that the PFBC has been bypassing a sufficient amount of sand to prevent a volumetric increase on the west side of the marina. 


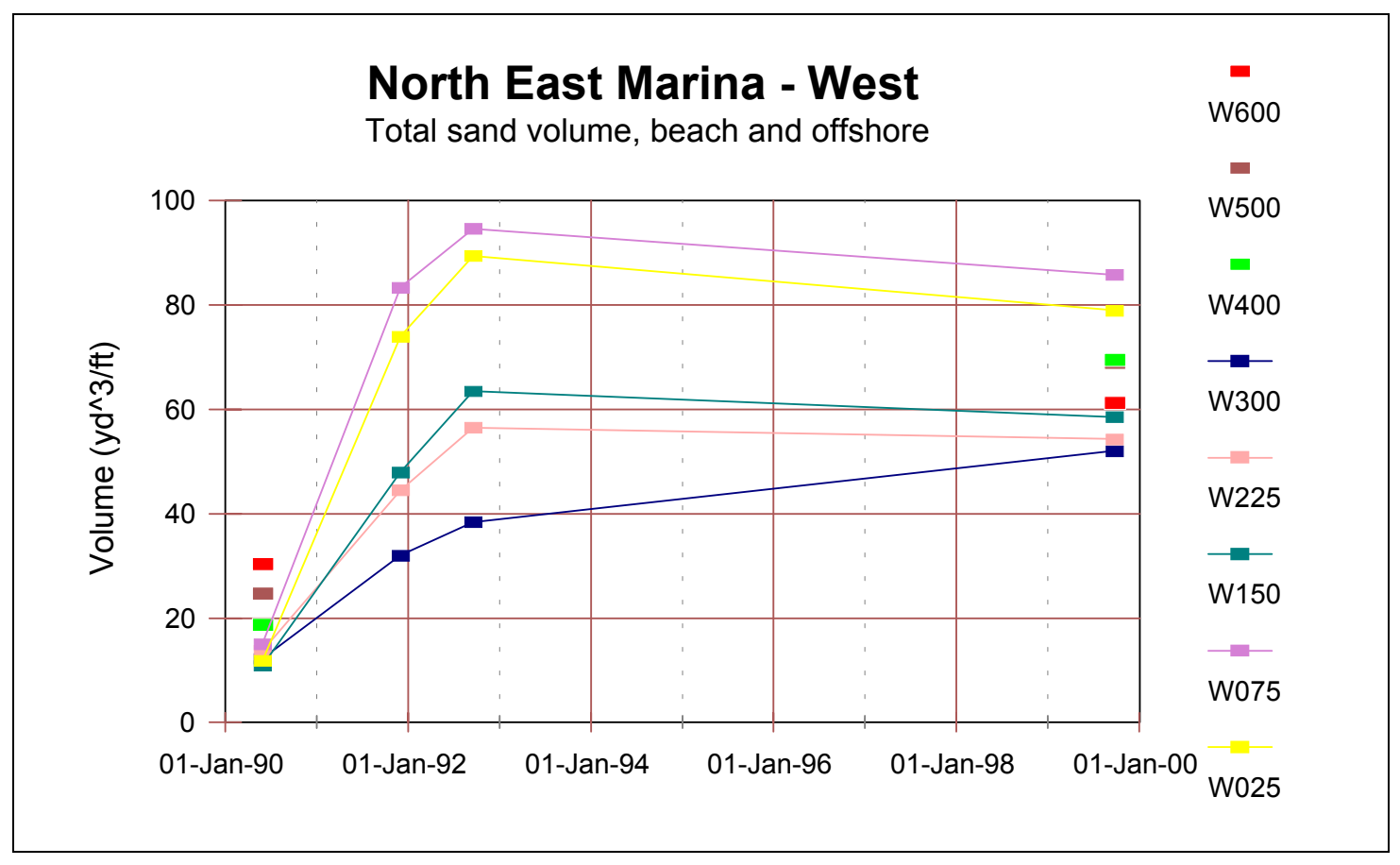

Figure 36. Profile volume for lines W025 to W600 west of marina west wall. At W400, W500, and W600, data are only available for 1990 and 1999 and points have not been connected in this plot

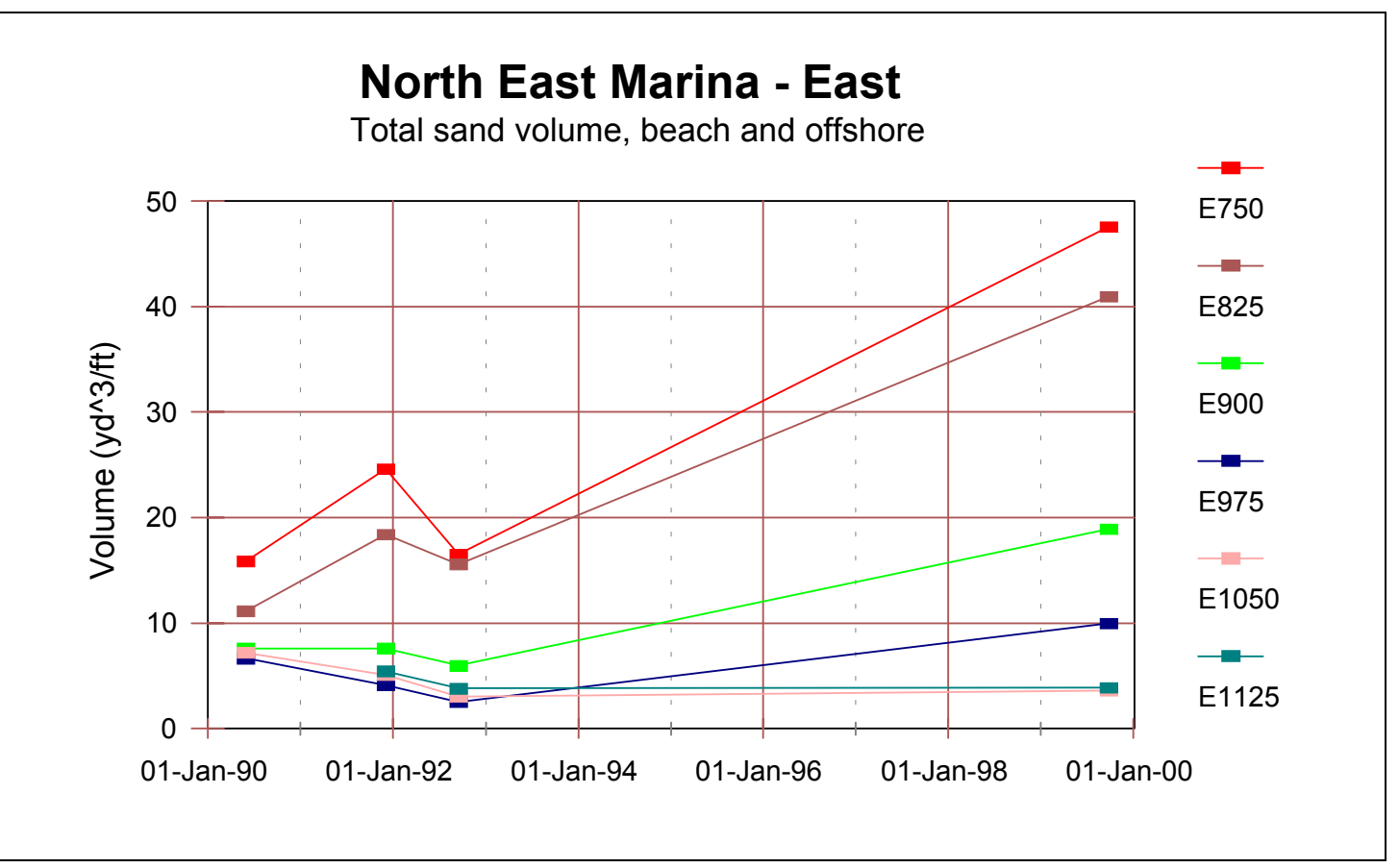

Figure 37. Profile volumes east of marina. Most profiles show an increase in volume since 1992, but E1050 and E1125 are beyond influence of the structure 


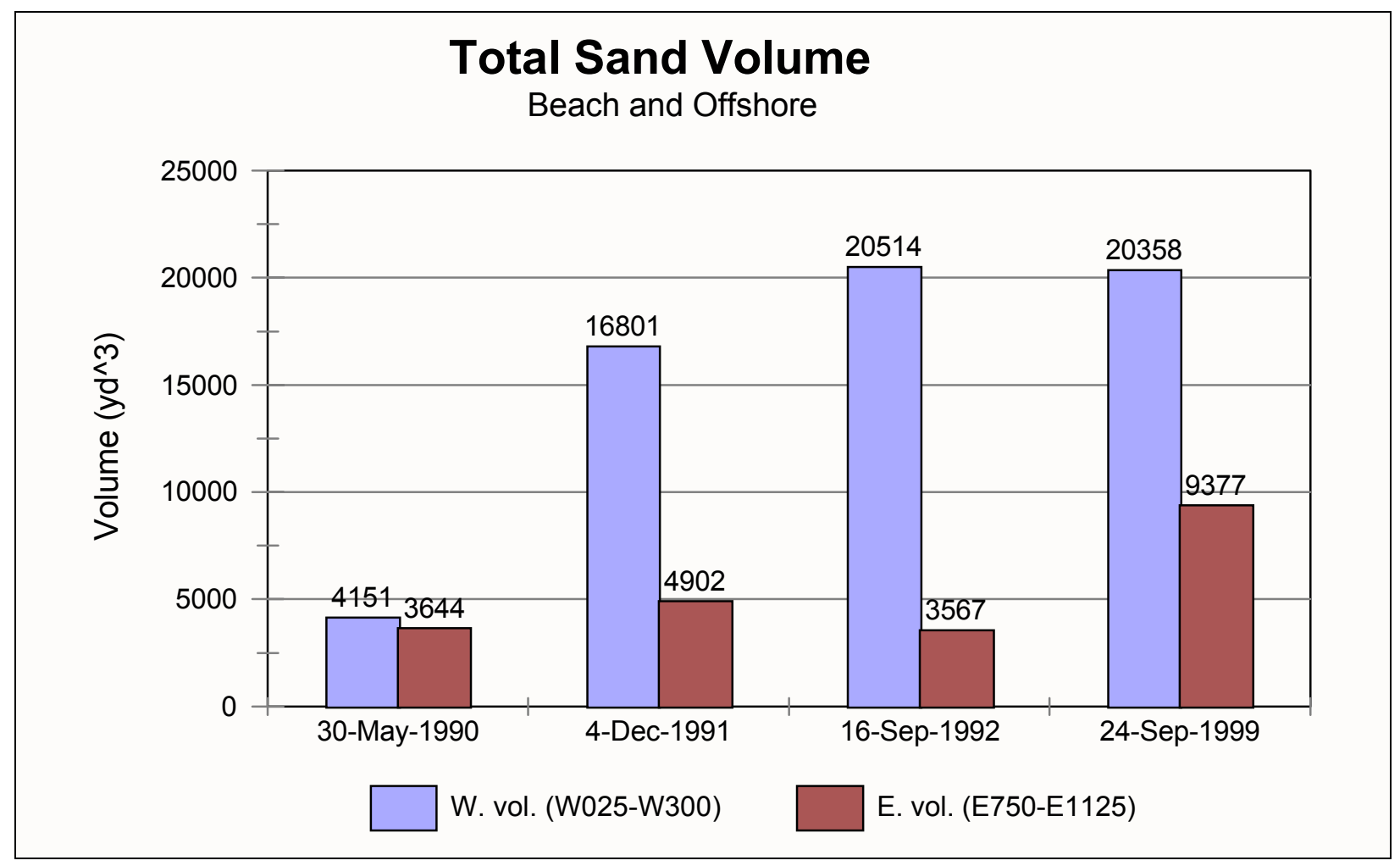

Figure 38. Total volume for west and east beaches. West of marina, volume has been stable since 1992, while to the east, total beach volume has almost doubled 


\section{Summary of Geological and Physical Process Findings}

What has been the effect of North East Marina on sediment processes in the stretch of coast between Peck Run and Twentymile Creek from 1990 to the present? The answer is best divided into two time frames:

Period 1: Spring 1990 (beginning of construction) through Spring of 1994 (initiation of bypassing by PFBC). The marinaís west wall blocked most of the east-moving littoral drift. This material accumulated in a fillet that extended from the west wall to about $300 \mathrm{~m}$ west. The total volume of sand west of the marina, between profiles W025 and W300, increased rapidly, from 4,000 to $16,000 \mathrm{yd}^{3}$ after construction of the project began. By September 1992, the volume increased again, to $20,000 \mathrm{yd}^{3}$ (Figure 38). The total sand accumulation between W025 and W600, using some assumptions regarding the preproject profile, was about $29,000 \mathrm{yd}^{3}$.

Period 2: Spring 1994 to the present. Pennsylvania Fish \& Boat Commission has effectively mitigated the disruption of eastward-directed littoral transport because the volume of sand bypassed during the biannual trucking operations has been approximately the same as the amount of sand brought into the fillet region by littoral processes. In September 1999, the total volume between profiles W025 and W300 remained unchanged at about 20,000 $\mathrm{yd}^{3}$, therefore indicating that the mechanical bypassing has been equal to the input supply (Figure 38).

This study revealed additional information on local geological and physical processes:

a. Most of Lake Eries south shore bluffs have been receding at least as long as dependable maps have been available. Near North East Marina, the 100 -year recession rate is in the order of $0.3 \mathrm{~m} /$ year, and the short-term rate, based on 1982-1987 data, is about $0.2 \mathrm{~m} /$ year. Based on this latter value, the bluffs in this area could have expected to have retreated about 2 $\mathrm{m}$ in the decade that the project has been in existence (without artificial protection or beach renourishment). 
b. Portions of the bluffs both west and east of the marinaís present location were protected with various structures in the 1970s and 1980s. This indicates that property owners were concerned about the high bluff erosion potential long before marina construction (Figures 16-23).

c. The volume of sand east of the marina has approximately doubled since 1992. This sand is found in a fillet that extends about $120 \mathrm{~m}$ east of the east wall (Figure 30). Part of this volume is in the upper beach, remnants of the temporary roadway placed by the PFBC.

d. The shape of early 1990s and 1999 profiles at W025, W075, and W150 are almost identical, showing that the west fillet near the marina has not changed shape to any significant extent nor grown in a lakeward direction.

e. Since November of 1993, the PFBC has bypassed an annual average of $16,700 \mathrm{yd}^{3}$ of sediment at North East Marina (Figure 24 and Table 4). The total amount of littoral material bypassed (excluding upland fill) has been about $105,000 \mathrm{yd}^{3}$.

f. Visual observations made by divers and underwater video confirm that most sand and gravel is restricted to the fillet area on the west side of the marina and to a more narrow band along the east beach. Once the edge of the sand is reached, the bottom consists of cobble or bare shale with only minor amounts of sand and gravel confined to cracks in the shale platforms. Lakeward of the marinaís outer wall, the bottom consists of cobble and shale with scattered patches of rippled sand. Some cobble may be bedding or chinking stone lost from the riprap, that has settled over time.

g. The side-scan sonar surveys and video observations did not detect any sand in deep water near or offshore of the marina that could be used as a source to renourish the east shores. The only obvious source of sand suitable for renourishment is the is the updrift (west) fillet.

$h$. Based on the analysis of profile volumes, line E1050 is the easternmost limit where the influence of the marina can be detected with respect to sediment accumulation (or loss) on the beach (Figure 30). This profile is about $120 \mathrm{~m}$ ( $400 \mathrm{ft})$ east of the east wall. Further east, the 1999 profile volume is essentially unchanged compared to 1991 and 1992. The quantity of sand on the beach in this area, east of E1050, is minimal, only about $4 \mathrm{yd}^{3} / \mathrm{ft}$.

i. $\quad$ Average lake level has dropped from 174.8 to $173.8 \mathrm{~m}(573.7$ to $570.3 \mathrm{ft})$ IGLD 1985 between April 1998 and February 2000 . A much broader beach is now present in the region from 100 to $200 \mathrm{~m}$ west of Twentymile Creek. Two factors probably account for the healthy state of this beach: dropping lake level and the regular sand bypassing. It is impossible to quantify which factor is more important in the area between the marina and Twentymile Creek, but regionally (over a scale of kilometers), the 
influence of falling lake level will completely drown out the minor perturbation caused by the marina.

$j$. Some sand may move around the outer wall of the marina during storms. The former PFBC marina manager, Mr. Gary Moore, reported that during an ice storm, the breakwater roadway freezes to a glossy surface upon which it is impossible to walk. If this is followed by a storm where waves break over the structure, the surface becomes gritty. The amount of sand moved during storms appears to be minimal because the only accumulations of sand in deeper water are scattered, thin veneers of rippled sand. Because of the stairstep pattern of the shale ledges offshore, it seems unlikely that this sand could move onshore.

$k$. Only a minor amount of sediment from the littoral system appears to enter the marina. The material that has been removed from within the basin consisted of organic debris and fine-grained material, probably a remnant from the original construction, when runoff from the bluffs and parking lot was allowed to flow into the basin. 


\section{Sediment Management Alternatives at North East Marina}

Profile data and aerial photographs have verified that North East Marina interrupted the movement of littorally-transported sand since the beginning of construction in 1990. The State of Pennsylvania has been bypassing material around the marina using trucks since 1994 to mitigate downdrift sediment loss. The goal of Phase II of this project was to determine the optimal long-term method of mitigation. To that end, a list of technically feasible options was developed and the advantages and disadvantages of each option were considered. Recommendations for future sediment management are made based on the analysis of those options. Three broad classes of solutions are discussed in the following paragraphs, in addition to a summary table (Table 9). The decision tree in Figure 39 shows how the mitigation alternatives were grouped, though it should be noted that the classifications are a convenient and logical hierarchy, but in reality some options could have been placed in more than one class of solutions.

\section{Cease Artificial Intervention}

Based on the analysis of cross-shore profiles (discussed earlier in this report), the marina has been trapping roughly $17,000 \mathrm{yd}^{3} /$ year of sediment in a fillet on the updrift (western) side, and mechanical sand bypassing by PFBC has kept the volume of that fillet at about $20,000 \mathrm{yd}^{3}$ since 1994 . One option would be to cease artificial sand bypassing and let the fillet grow, allowing natural littoral processes to eventually bypass the sand. Once truck bypassing stopped, the fillet would grow lakeward until it reached the northwest corner of the marina, whereupon sand and cobble could move past the corner and be transported along the outer breakwater. Eventually, the sediment would be transported past the northeast corner of the marina and (presumably) be carried towards the shore. This alternative provides definite benefits for the updrift property owners since the beaches fronting their property would grow significantly due to the accumulated sediment in the fillet. However, there are several negative aspects to this plan which include the following: 


\begin{tabular}{|c|c|}
\hline \multicolumn{2}{|c|}{$\begin{array}{l}\text { Table } 9 \\
\text { Alternative Engineering and Management Solutions, North East Marina }\end{array}$} \\
\hline Solution & Recommendation \\
\hline Cease Artificial Intervention & $\begin{array}{l}\text { Permanent loss of material offshore, unknown time frame, } \\
\text { failure to nourish east beach }\end{array}$ \\
\hline \multicolumn{2}{|l|}{ Change Geometry of Shore or Structures } \\
\hline \multicolumn{2}{|l|}{ Alter marina } \\
\hline $\begin{array}{l}\text { Complete removal of North East Marina breakwater walls } \\
\text { and riprap }\end{array}$ & $\begin{array}{l}\text { Cost-prohibitive, need for harbor of refuge along this coast, } \\
\text { debris disposal }\end{array}$ \\
\hline Partial removal or marina walls & Reduced protection for boats, tombolo formation, high cost \\
\hline \multicolumn{2}{|l|}{ Fixed structures } \\
\hline Shore-perpendicular groins along beach east of marina. & $\begin{array}{l}\text { Detrimental downdrift effects, cost-prohibitive, requires } \\
\text { beach fill }\end{array}$ \\
\hline Detached breakwaters along east beach. & Cost-prohibitive, requires beach fill \\
\hline Headland or on-shore breakwaters to perch the shoreline & Cost-prohibitive, requires beach fill \\
\hline Revetment/seawall along east beach. & Property protection only, no benefit to beach \\
\hline $\begin{array}{l}\text { Above structure options considering alternative construction } \\
\text { material (i.e., precast concrete units, geotextile, etc.) }\end{array}$ & Cost-prohibitive, typically ineffective in Great Lakes \\
\hline \multicolumn{2}{|l|}{ Prevent Downdrift Starvation } \\
\hline \multicolumn{2}{|l|}{ Beach fill from external sources } \\
\hline Dredge sand from submerged sites & No nearby offshore source \\
\hline $\begin{array}{l}\text { Mine the spit at the mouth of Twenty Mile Creek and back- } \\
\text { pass the material to the east beach }\end{array}$ & Detrimental downdrift effects \\
\hline Purchase and import sand by truck from an inland source & Cost-prohibitive, disruptive to community \\
\hline $\begin{array}{l}\text { Combine backhoe and truck sand bypassing with external } \\
\text { sand supply }\end{array}$ & Not needed \\
\hline Place coarser, more stable gravel or cobble on east beach & Reduced recreation \\
\hline \multicolumn{2}{|l|}{ Sand bypassing using west beach fillet } \\
\hline Continue sand bypassing using existing procedures & Optimum solution for North East Marina \\
\hline $\begin{array}{l}\text { Bypass using existing procedure (backhoe and trucks) but } \\
\text { more frequently or on a flexible schedule. }\end{array}$ & Not needed \\
\hline $\begin{array}{l}\text { Increase the quantity to be by-passed by mining a larger } \\
\text { portion of the west beach fillet }\end{array}$ & Not needed \\
\hline Portable hydraulic sand bypassing & Limited technical feasibility \\
\hline Fixed hydraulic sand bypassing & Low probability of success, cost-prohibitive \\
\hline
\end{tabular}




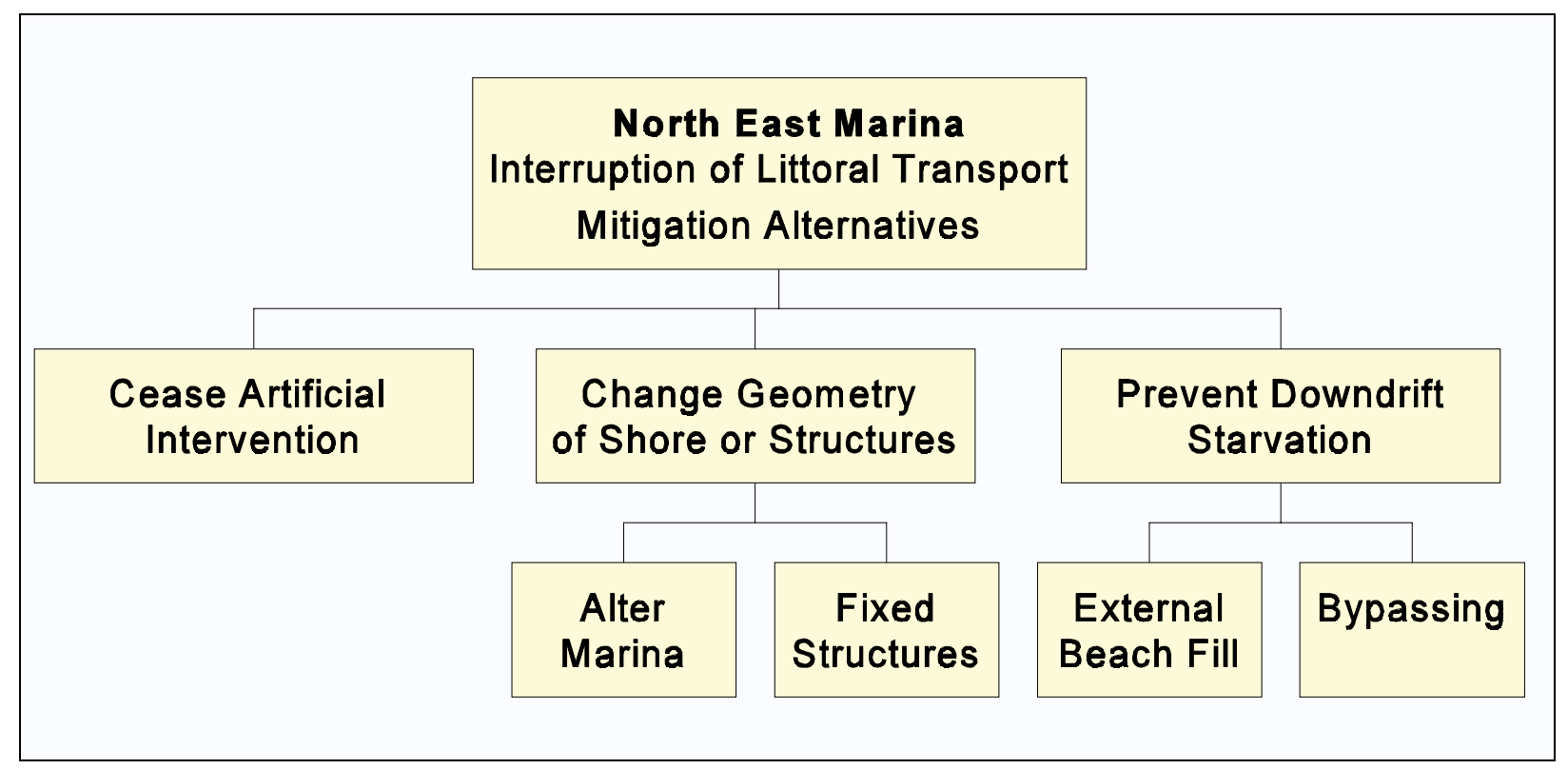

Figure 39. Flow chart of mitigation alternatives

a. Permanent loss of material. Side scan sonar surveys showed that several large joints and shallow terraces in the shale bedrock immediately north of the marina. It is likely that some, possibly a significant amount, of sediment will flow over the terraces or into the joints. Given the wave climate in the area and the geometry of this surface, it is unlikely that the material would be carried landward along the shale and on to the beaches.

b. Spit formation near marina entrance. Aerial photographs already show the beginnings of a small spit forming at the northeast corner of the marina. If natural bypassing around the marina is encouraged, the spit would act as a sink for transported material, preventing it from reaching shore. As the spit continued to grow, it would most likely curve around towards shore and eventually encroach on the entrance to the marina, in which case it would have to be dredged. Waves with a significant northerly component will push sediment from the spit into the fillet on the eastern side of the marina. This fillet lies in a low wave energy area and would have to be mechanically mined in order to move the sand onto the downdrift beaches to the east.

c. Failure to nourish eastern beach. The fraction of sediment that does bypass the marina successfully may not actually reach the beach. Given the terraced nature of the bedrock it is very likely that sand and cobble remain in the nearshore region. For sand to move onshore, waves have to suspend it sufficiently for it to jump over the steps. Cobble and gravel are not entrained in the waves and this fraction would remain offshore. 
d. Unknown time frame. Assuming that the western side of the marina acts as high, impermeable groin and that the average wave angle is $30 \mathrm{deg}$ from the west, a rough calculation of the time needed to begin natural bypassing can be made. Assume that the beach profiles will be linear and that the toe of fillet face will reach to the end of the marina wall with a $45 \mathrm{deg}$ angle of repose. Based on these assumptions a triangular fillet with a volume of roughly $18,000 \mathrm{yd}^{3}$ will form. Assuming a natural littoral drift of $17,000 \mathrm{yd}^{3} /$ year, it would take slightly over a year before any sand started moving around the marina. The sediment would then have to move along the northern face of the marina, around northeast corner and up to the beach. Even if a significant fraction of the sand could successfully move around the marina, it might take several years before any actually reaches the eastern shore. Also, as discussed above, sand and coarse sediment will likely remain offshore indefinitely, resulting not only in a loss of volume but a change in the sediment composition on the downdrift beaches.

In summary, the option of ceasing artificial bypassing is not viable at this site. Given the reasons previously outlined, the benefits to the updrift landowners do not outweigh the probable losses to the littoral system and the downdrift landowners during the period of years that natural bypassing might be re-established is highly unlikely that full bypassing would occur.

\section{Change Geometry of Shore or Structures}

\section{Alter the marina}

Since littoral drift is interrupted by the marina, it follows that altering the layout of the marina to alleviate the problem is a logical option. Two options are possible:

a. Complete removal of marina. The marina is popular with local residents and tourists and is actively used six months of the year, demonstrating that there is a need for some sort of recreational facility. This facility is also the only harbor of refuge between Erie and Barcelona, a distance of 48 $\mathrm{km}$. Removal would certainly be controversial and would adversely affect public safety. Furthermore, complete removal of North East Marina breakwater walls and riprap was considered in 1993 and rejected because of the total cost was estimated to exceed $\$ 2$ million. Costs have escalated since then, and this alternative assumes that all permitting can be obtained.

b. Partial removal of walls to allow littoral sediment transport. An alternative is to remove sections of the western, eastern, and northern walls, allowing waves to carry sediment through the marina to the eastern beaches. At the same time the walls must be oriented to keep a cuspate spit or tombolo from forming in the marina or in the lee of the structure (a 
difficult design problem). Tombolos are sediment accumulations that form in low wave energy zones behind detached breakwaters or similar structures. A large tombolo could fill in a significant portion of the marina, preventing boaters from entering their slips and stopping longshore sediment transport. As a result, the marina would have to be periodically dredged to maintain the working depth. Removing enough of the walls to prevent a tombolo would severely impact function of the marina as a harbor of refuge.

In summary, removing all or sections of the marinaís breakwaters does not appear justified for the following reasons:

a. Reduced protection from storm waves provided to boats.

b. The risk of tombolo formation (and the resulting need to dredge).

c. High costs.

d. Disruption during work and difficulty of debris disposal.

\section{Addition of fixed structures}

Various structures have been built along coasts around the world to modify littoral drift (groins) or prevent erosion (seawalls or revetments). Groins are typically long, thin structures oriented perpendicular to the shoreline and spaced at intervals of two to three times their length. Presently, in most properlyengineered groin projects in the United States, the area between the structures is filled with sand, reducing the volumetric impact to the littoral system caused by trapping sediment. If a storm erodes some of the fill between the groins, then subsequent littoral drift is trapped until the groin pockets are full again. In the past (pre-1950s), groins were often built without the addition of extra fill, with the assumption that natural drift would fill the pockets. This resulted in serious downdrift sediment starvation for many years along with associated erosion and, often, property destruction. Additionally, sand eroded from groins placed near the marina may fall over the shale terraces and be lost to the littoral system, requiring periodic noursihment.

Predicting shoreline response to fixed structures is notoriously difficult, and it is possible that a structure may have unexpected negative consequences. One typical response is that beaches downdrift suffer for many years because their sand supply has been interrupted. Any comprehensive groin project would also require a major artificial fill, which raises the challenge of finding, purchasing, and delivering suitable quantities of fill from the fillet or an external source.

Detached breakwaters are another type of structure often used to shelter a section of the shore from storm waves. A properly-designed detached breakwater project provides protection while still allowing some or most of the littoral drift to move along the shore. Presque Isle, PA, is an example of this application on the 
Great Lakes. Beach fill is usually required, and construction costs can be high, particularly if an offshore plant is used.

Headland or onshore breakwaters can be used to perch the beach at an elevated level. This type of project requires fill and typically reduces the value of the beach for recreation because access to the water is difficult. It can also have a negative downdrift impact by trapping sediment.

Properly designing a coastal structural project is a significant engineering effort, requiring geologic and physical process measurements and numerical and physical modeling. Unless done correctly by experienced coastal engineers, the success of such projects is mixed. Construction in the lacustrine environment is difficult and costly. For example, at Maumee State Park in Lucas County, Ohio, a recreational beach was built using detached breakwaters and sand fill. The Federal portion of the project cost $\$ 8,300,000$ (October 1991), and the nonFederal cost was about $\$ 12,700,000 .^{1}$ Postconstruction beach monitoring and sand nourishment at Maumee will continue for 50 years.

A mixture of revetments, seawalls, and gabions already exist along part of the east beach (Figure 16). A more comprehensive seawall or revetment along the entire reach from the marina to Twentymile Creek would protect the property only from wave erosion, and would not benefit the beach. While no more aesthetically displeasing than the current structures, such coastal structures would limit access to the shore, have an unnatural appearance, and would require longterm maintenance.

Dozens of alternative construction materials, configurations and shapes have been proposed for use in the coastal zone to prevent erosion. Most proposals were variations of existing designs (such as groins or breakwaters), but used geotextiles or precast concrete units or rubber tires in unusual ways. Many of these proposals have been presented as magical solutions with a large degree of quackery and little verifiable supporting data or engineering support for the design. Many alternative materials will not survive the harsh Great Lakes environment, with its combination of intense, short-period storm waves, ice ridges, freeze-thaw cycles, and fluctuating water levels.

Given the difficulty and cost of effectively designing and building groins or offshore breakwaters, we recommend that fixed (permanent) structures not be considered at this time. Several years of beach survey information should be collected and examined to determine long-term impact of the marina and the effects of sand bypassing before fixed structures are considered. In addition the shore protection benefit of such structures would mitigate more damage than that associated with the marina. Thus, the cost of such structures would need to be borne jointly by the state and the private property beneficiaries.

\footnotetext{
${ }^{1}$ From USACE Digital Project Notebooks:

http://crunch.tec.army.mil/dpn/webpages/dpn.cfm 16 April 2001
} 


\section{Prevent Downdrift Starvation}

\section{External beach fill}

Before the PFBC began bypassing in 1994, a volume of approximately $29,000 \mathrm{yd}^{3}$ was lost to the littoral system by being trapped in the updrift fillet. The lost sediment was partly replaced in 1993-1994, when 17,000 $\mathrm{yd}^{3}$ of sand was brought from an inland site and placed on the beaches to the east. Profile surveys from 1994 and 1999 show that the volume of the updrift fillet is unchanged (with no evidence of offshore sand loss), meaning that the present rate of mechanical bypassing is approximately equal to the rate of sediment supply when considering normal system variability. This implies that no additional material is required from external sources to compensate for trapping in the fillet.

Even though external beach fill is not required, it may appear to be an easy way to rapidly increase beach height and width. However, there are several factors to be considered before importing material, of which the two most important are sediment composition and cost. Imported sediment that is finer on average than the local sediment would provide a better beach for bathing, but the imported sand would wash away more quickly during storms. On the other hand, coarser imported material would provide better storm protection, but would form a steeper, gravelly beach that has less appeal for bathing and related activities. Ideally, any imported material would closely match the composition and grain size distribution of the local sediment.

Importing material is generally not as expensive as building a structure, but the mining, transportation, and distribution of fill quickly raise the overall cost. The following list comments on the economic viability of fill sources. They are as follows:

a. Dredge sand from submerged sites. Side-scan sonar, diver surveys, and the SHOALS airborne survey did not document any offshore sand deposits suitable for mining. There may be sand deposits just offshore at the mouth of Peck Run, but mining there would detrimentally change the public swimming beach that has formed at the headland. We do not know how thick the deposits of sand off Peck Run are, but the geomorphic evidence suggest that offshore sand accumulations in this area are veneers at best. Dredging these would be technically difficult and would probably entrain significant amounts of shale debris. Contracting for commercial dredging equipment usually involves major mobilization costs (in the range of 10's or 100's of thousands of dollars), and normally dredging can only be economically justified if there is a significant amount of material to move. Furthermore, sediment moving along the Lake Erie shore would likely be trapped in the dredged areas, further removing sediment from the littoral system.

b. Mine the spit at the mouth of Twentymile Creek and backpass the material to the east beach. Aerial photographs show the continued 
existence of a large spit at the mouth of Twentymile Creek with the shape suggesting that the dominant transport direction is eastward. Over time, the spit grows longer and longer, forcing the creek into a channel that empties farther and farther to the east. Eventually the channel becomes hydraulically inefficient or a storm breaches the spit near the original mouth of the creek. The remaining sandbar slowly erodes or welds onto the downdrift shore. It may be tempting to back bypass sand by truck from the sandbar to the western beaches, but removing this sand will disrupt the shorelines east of Twentymile Creek, essentially moving the area of sand starvation from one reach to another. In addition, the ownership of this material at Twentymile Creek would have to be established, and the state may have to purchase the sand. Also, appropriate permits would have to be obtained.

c. Purchase and import sand by truck from an inland source. In October of 1993, the PFBC purchased 12,000 $\mathrm{yd}^{3}$ of sand from an inland site for about $\$ 95,500$ and placed it on the east beach. The cost per $\mathrm{yd}^{3}$ of sand was $\$ 7.95$ not including placement costs, which are estimated to have

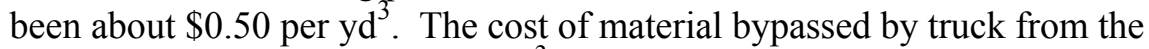
west fillet is on the order of $\$ 1 / \mathrm{yd}^{3}$, so that the cost of importing material is approximately eight times the cost of bypassing from the updrift fillet to the east beach. Beyond costs, technical consideration make this option unappealing. Heavy trucks carrying sand over the rural roads would be disruptive to residents. Construction equipment traffic would cause wear and tear to narrow local roads. Also, it may be difficult to find an inland source that has similar sediment composition and characteristics and can also supply the necessary volume.

d. Place coarser, more stable, material on the beach. Coarser sediment than is naturally found on the beach could be more stable over time. Disadvantages include increased beach steepness and less appeal for recreation purposes.

We must emphasize again that currently there is no engineering need for material from an external site. From a volumetric basis, the sediment permanently trapped in the western fillet was largely replaced by fill in 19931994, so no further fill is required. From a cost effectiveness vantage, importing sediment is an expensive operation for material that may be largely washed away within a year. Based on engineering and economic analysis, we recommend beach fill from external sources not be considered at this time. Again, continued monitoring and reassessment is recommended. It may be appropriate to reconsider this option should the downdrift situation change for the worse or if material from the updrift fillet becomes unavailable. 


\section{Sand bypassing options using material from west beach fillet and beach}

Increase the quantity to be bypassed by mining a larger portion of the west beach fillet (real estate and permitting allowances for up to the entire west beach fillet). Purchase of additional real estate is not needed at this time because surveys west of the marina indicate that the bypassing rate is keeping the west fillet at a constant volume. As discussed earlier, the current bypassing rate is sufficient to match the natural, undisturbed transport rate. Acquiring extra lakefront property might be justified if it enabled a more efficient bypassing operation (for example, allowing the backhoe to obtain material closer to shore in poor weather). Otherwise, no further beachfront access is needed for mining sufficient sand to approximately equal the natural rate of littoral movement.

Hydraulic bypassing using a portable or fixed hydraulic sand bypassing system at the west side of the marina. Either hydraulic option would be operated on a semicontinuous basis throughout the ice- free part of the year in response to sediment accumulation in the west beach fillet. When considering a hydraulic bypassing system for this area, the issues are essentially the same for a jet pump or a submerged pump in a fixed system, so only the jet pump system will be discussed in detail. The original operators of Safe Harbor Marina tried hydraulic sand bypassing with a 4x4x6-in. Pekor jet pump during the winter of 1993. The dimensions describe the intake, water supply, and outflow flange sizes, respectively. Realistically, pipes with a nominal diameter on the order of $10 \mathrm{in}$. would be needed to bypass the sand and most of the cobble, which in turn requires a large pump to move the slurry fast enough to keep the gravel from settling in the pipes and clogging the system. For 10-in. diameter pipes, a 375-hp pump with $400 \mathrm{ft}$ of supply head would be required to move $131 \mathrm{yd}^{3} / \mathrm{hr}$ $\left(100 \mathrm{~m}^{3} / \mathrm{hr}\right)$ of sediment $\left(\mathrm{d}_{50}=0.39 \mathrm{inch}\right)$ to just beyond the downdrift fillet. A booster pump would be needed to move the sediment beyond the zone where sediment has accumulated to date, about $120 \mathrm{~m}$ east of the east wall. Assuming the jet pump operated as expected without being clogged by cobble, it would take two sessions of eight 8 -hr days to bypass $17,000 \mathrm{yd}^{3}$ of sediment in 1 year (operating at $131 \mathrm{yd}^{3} / \mathrm{hr}$ ), one session in the spring and one in the fall. Based on the 1993 experiences of Safe Harbor Marina, it is likely that the effective operating time (EOT) could be as low as one third the anticipated operating time, meaning it would take three times longer than predicted to accomplish the bypassing due to maintenance, clogging, etc., so each session could last up to 24 days.

Jet pump systems have been successfully used in sand-rich environments where the proportion of gravel and cobble is minimal. Successful uses have mostly been on barrier island coasts not subject to freezing, such as Florida and Australia. Eastern Lake Erie, with beaches that consist of a sand, gravel, cobble, shale, wood, and anthropogenic debris such as tires, plastic and metal, is not an ideal environment for efficient hydraulic bypassing. If a successful method of excluding cobble and debris from the inlet were developed, it would cause larger cobbles to accumulate in the western fillet while smaller material was bypassed. Eventually the cobble would have to be bypassed by truck because the cobble is 
an essential component of the littoral material. Because of the sediment composition and harsh winter weather, we recommend that truck/backhoe bypassing continue since this method already moves the needed amount of sediment and can readily accommodate varying size material.

Bypass using the existing procedure (backhoe and trucks), but more frequently or on a flexible schedule. Bypassing during the winter is not advisable for physical and safety reasons. First, winter ice often covers the west fillet, making it difficult to mine. Rubble ice, ice hummocks, and rafted ice on or near the downdrift beach may make it impossible to deliver the fill once it is mined (Figure 9). Winter storms and severe cold may also delay bypassing for significant periods. There are also the safety issues involved when working on or near ice-covered waters in the winter, especially when the air temperature is very cold. Bypassing during the summer months is not advised because it would interrupt the activities of marina users and visitors trying to enjoy the lakefront. Bypassing in early October provides protection for the bluffs from winter storms while bypassing operations in late March or early April are finished before the summer recreation season and provide some time for the fill to adjust to a more natural configuration over the beach. Therefore, the current schedule of sand bypassing is appropriate for this site.

Continue sand bypassing using existing procedures (backhoe and trucks), on similar schedule (spring and fall) and similar annual quantities. The amount to be bypassed is determined from surveys of the updrift (west) and downdrift (east) fillets. Using data from the last survey (24 September 1999), the updrift fillet contained $19,700 \mathrm{yd}^{3}$ of sediment, which is roughly equal to the $20,000 \mathrm{yd}^{3}$ it contained after the 16 September 1992 survey. The methods used to determine these volumes are discussed in Chapter 5 of this report. The PFBC has been mining and bypassing sediment from the west fillet since 1994 at an average rate of $16,700 \mathrm{yd}^{3} / \mathrm{yr}$. As shown in Chapter 5, the average volume of the west fillet has remained constant during that time, which implies that the natural sediment transport rate in the area is roughly equal to the average bypassing rate. As such, the current bypassing rate is sufficient to mimic the amount of sediment that would reach the downdrift side of the marina through natural processes if the marina were not present.

The east fillet grew from 3,570 $\mathrm{yd}^{3}$ in 1992 to $9,380 \mathrm{yd}^{3}$ in 1999, a change of $5,810 \mathrm{yd}^{3}$ over 7 years $\left(\approx 800 \mathrm{yd}^{3} /\right.$ year $)$. Occasional waves from the north or northeast could have created the fillet due to longshore sediment transport from the east, but it is more likely that the fillet formed from sand and cobble washed out of the roadbed (which was constructed out of bypassed material) into the low wave energy area adjacent to the marina. We recommend that the downdrift fillet be left as it is because the increased beach width and beach height provides some additional measure of protection from waves for the shore up to $80 \mathrm{~m}(250 \mathrm{ft})$ east of the marina. However, should this fillet grow to a degree that it contributes to shoaling at the marina entrance, it may have to be dredged.

In the past, the plaintiffs have requested that the PFBC build a berm along the foot of the bluff to provide vertical height to the beach. At this time there is no 
consensus as to a method or geometry of beach fill that would optimize both beach height and bluff protection. One method of placement would be to build the access road in the normal manner, effectively providing a 1 to $2 \mathrm{~m}$-high berm of packed sand and cobble, then place piles of fill on the landward edge of the road at the base of the bluffs. The roadbed would extend eastward from the marina by necessity, but the additional fill would be placed east of profile E1050 (120 $\mathrm{m}$ from the marina) to minimize the volume of material carried into the east fillet by waves. The roadbed and fillet should provide sufficient beach width and bluff protection without additional material. Extending the road as far as profile E2200 provides new beach material and bluff protection to the reach affected by the marina. It must be emphasized that the berm provides protection to the bluffs by dissipating wave energy and in the process they are eroded, slowly spreading over subaerial and subaqueous parts of the shore. The fill is not gone, it is just more evenly distributed over the beach. The rate at which the berm erodes depends on many factors: changes of water level, wave climate, period of ice cover and groundwater runoff from the bluffs. The important aspect of the berm erosion is that the bluffs are being protected and new material is gradually released to the beach.

The existing method of bypassing at North East Marina two times per year by truck has the advantage of creating a packed berm as part of the distribution process, so no additional equipment is needed. Additionally, the truck bypassing procedure is flexible and adaptable and can be accomplished by Pennsylvania state employees using equipment already owned by the state. Unlike hydraulic bypassing, truck bypassing can handle sand, gravel, cobble, driftwood, and debris without risk of clogging the system. At a cost of roughly $\$ 1.00$ a cubic yard, it is also a cost-effective method.

We recommend that this bypassing procedure be continued at Northeast Marina indefinitely. Material moved from the west side of the marina should be used to build a roadbed for the trucks, and excess material should be placed on the shore beyond profile E1050, about 120 m east of the east wall and up to a distance of about $500 \mathrm{~m}$ (the eastward limit of disposal is not critical). 


\section{Recommendations}

The present practice of bypassing material that accumulates on the west (updrift) side of North East Marina twice a year has been fully effective in moving as much sediment as is naturally supplied by the littoral drift. No more material could be easily bypassed without mining the portion of the fillet that is on private property or bringing in material from an upland source. Between 1993 and 1999, the annual volume bypassed ranged from 13,000 to $23,000 \mathrm{yd}^{3}$ and averaged $17,000 \mathrm{yd}^{3}$.

It is not possible to state that there is one optimum volume that should be bypassed each year, but 7 years of data indicate that it should average around $17,000 \mathrm{yd}^{3}$. The current method of moving all material that can be readily excavated from the beach and underwater portion of the fillet with a backhoe is an effective way to respond to varying littoral drift over time.

The PFBC has been unable to move all the material stored in the fillet, as some is on private property. However, there is no compelling need to acquire extra material from an inland site in a volume equal to the material stored in the updrift fillet for the following reasons:

a. About 29,000 $\mathrm{yd}^{3}$ of sand and gravel accumulated west of the marina during project construction (Table 8). In 1993 and 1994, PFBC supplied $17,000 \mathrm{yd}^{3}$ from inland sources, and since then has been bypassing a sufficient volume to equal the natural littoral drift. Therefore, additional artificial fill from an inland site would only be replacing a portion of the sediment initially lost from the system in 1991-1993, about $12,000 \mathrm{yd}^{3}$.

b. For a distance of about $150 \mathrm{~m}$ east of the marina, the beach has greater volume now than before the project was built. Therefore, the sheltering effect of the marina and the biannual bypassing is having a positive effect on the east beach closer than profile line E1050.

c. Beyond Profile 1050, the shore is unchanged between preconstruction and the present, based on a comparison of cross-shore profiles. Sediment in the littoral drift appears to bypass this portion of the beach and continue moving east. Therefore, it is highly unlikely that adding $12,000 \mathrm{yd}^{3}$ of 
sand purchased from an upland site would have any more positive benefit than the similar volume bypassed annually by PFBC.

Falling lake level is the most important factor influencing the width of the beach beyond profile E1050. The lake effect is much greater than the influence of the marina (i.e., the lake "signal" overwhelms the marina signal).

We do not recommend structural (hard) alternatives at this time because of engineering and construction challenges, possible detrimental downdrift effects, high costs, and disruption to the community during construction. The present bypassing procedure needs to be monitored as conditions change and the site monitored before hard structures are considered. 


\section{References}

Belderson, R. H., Kenyon, N. H., Stride, A. H., and Stubbs, A. R. (1972). Sonographs on the sea floor. Elsevier Publishing Company, Amsterdam, The Netherlands.

Carter, C. H. (1977). "Sediment-load measurements along the United States shore of Lake Erie," Report of Investigations No. 102, Ohio Department of Natural Resources, Division of Geological Survey, Columbus, OH.

Carter, C. H., Neal, W. J., Haras, W. S., and Pilkey, O. H. (1987). Living with the Lake Erie Shore. Duke University Press, Durham NC.

Chrzastowski, M. J., and Schlee, J. S. (1988). "Preliminary sidescan-sonar investigation of shore-defense structures along Chicagos northside lake front: Wilson Avenue groin to Ohio Street beach," Environmental Geology Notes 128, Department of Energy and Natural Resources, Illinois State Geological Survey, Champaign, IL.

Clausner, J. E., and Pope, J. (1988). "Side-scan sonar applications for evaluating coastal structures," Technical Report CERC-88-16, U.S. Army Engineer Waterways Experiment Station, Vicksburg, MS.

Coordinating Committee on Great Lakes Basic Hydraulic and Hydrologic Data. (1992). IGLD 1985, Brochure on the International Great Lakes Datum 1985, Government Printing Office, Washington, DC.

Driver, D. B., Reinhard, R. D., and Hubertz, J. M. (1991). "Hindcast wave information for the Great Lakes: Lake Erie," Wave Information Studies of U.S. Coastlines, WIS Report 22, U.S. Army Engineer Waterways Experiment Station, Vicksburg, MS.

Geier, R. J., and Calkin, P.E. (1983). "Stratigraphy and bluff recession along the Lake Erie coast, New York," New York Sea Grant Institute, Albany, New York. 
Gorman, L. T., Morang, A., and Larson, R. L. (1998). "Monitoring the Coastal Environment; Part IV: Mapping, shoreline change, and bathymetric analysis," Journal of Coastal Research 14(1), 61-92.

Grosskopf, W. G., and Kraus, N. C. (1994). "Guidelines for surveying beach nourishment projects," Shore \& Beach 62(2), 9-16.

Great Lakes Commission. (1986). "Water level changes: factors influencing the Great Lakes," Great Lakes Commission, Ann Arbor, MI.

International Joint Commission. (1993). "Methods of alleviating the adverse consequences of fluctuating water levels in the Great Lakes-St. Lawrence River basin: A report to the Governments of Canada and the United States," Washington, DC and Ottawa, Ontario, December 1993.

International Niagara Working Committee. (1999). "1998-1999 operation of the Lake Erie-Niagara River ice boom," Report to the International Niagara Board of Control, U.S. Army Engineer District, Buffalo, Buffalo, NY.

Knuth, P. D., and Crowe, R. G. (1975). "Identification and analysis of Lake Erie coastal hazard areas," Pennsylvania Department of Environmental Resources, Harrisburg, PA.

Knuth, P. D. (1987). "Lake Erie bluff recession rate data update," Report prepared by Coastal Research Associates for the Erie County, Pennsylvania Department of Planning and the Department of Environmental Resources, Coastal Zone Management Division, Harrisburg, PA.

Leenhardt, O. (1974). "Side scanning sonar - a theoretical study." International Hydrographic Review 51(1), 61-80.

Mather, W. W. (1838). Second annual report of the geological survey of the state of Ohio. Samuel Medary, printer to the state, Columbus, $\mathrm{OH}$.

Morang, A. (1987). "Side-scan sonar investigation of breakwaters at Calumet and Burns Harbors on southern Lake Michigan," Miscellaneous Paper CERC87-20, U.S. Army Engineer Waterways Experiment Station, Vicksburg, MS.

Morang, A., Larson, R. L., and Gorman, L. T. (1997a). "Monitoring the coastal environment; Part I: Waves and currents," Journal of Coastal Research 13(1), 111-133.

Morang, A., Larson, R. L., and Gorman, L. T. (1997b). "Monitoring the coastal environment; Part III: Geophysical and research methods," Journal of Coastal Research 13(4), 1964-1085.

Morang, A., Mossa, J., and Larson, R. L. (1993). "Technologies for assessing the geologic and geomorphic history of coasts." Technical Report CERC-93-5, U.S. Army Engineer Waterways Experiment Station, Vicksburg, MS. 
Shore Protection Manual. (1984). $4^{\text {th }}$ ed., 2 Vol, U.S. Army Engineer

Waterways Experiment Station, U.S. Government Printing Office, Washington, DC.

Sommerfeld, B., Mason, J. M., Kraus, N. C., and Larson, M. (1994). "BFM:

Beach fill module, Report 1, beach morphology analysis package (BMAP). userís guide," Instruction Report CERC-94-1, U.S. Army Engineer Waterways Experiment Station, Vicksburg, MS

Stewart, C. J. (1994). "United States Great Lakes shoreline recession rate data final report," Report prepared for the U.S. Army Engineer District, Detroit, and the Coastal Engineering Research Center, Contract DACW39-93-M-6861 and DACW39-94-M-3972.

Stewart, C. J. (1998). "Lake Ontario and Lake Erie data collection activities, lower Great Lakes erosion study," Report submitted by VGI Vision Group International, Victoria, British Columbia, to the U.S. Army Engineer District, Buffalo, Contract No. DACW39-97-D-0007.

Taylor, K., and Buyce, M. R. (1994). "Coastal environmental investigation of the safe harbor marina, North East Township, North East, Pennsylvania," Report prepared by TBS Consulting, North East, PA, for Pennsylvania Fish and Boat Commission, Bellefonte, PA.

Thompson, T. A., and Baedke, S. J. (2000). "A geologic perspective on Lake Michigan water levels," Great Lakes Update, Vol. 140, U.S. Army Engineer District, Detroit.

Wright, L.D., and Short, A. D. (1984). "Morphodynamic variability of surf zones and beaches: a synthesis," Marine Geology 56, 93-118. 


\section{Appendix A Chronological List of Events and Engineering Activities}

Table A1 lists historical and construction events and sediment bypassing at North East Marina.

\begin{tabular}{||l|l|l|l||}
\hline \hline Table A1 \\
Event and Activity \\
\hline \hline Chronology, North East Marina, Erie County, PA
\end{tabular}




\begin{tabular}{|c|c|c|c|}
\hline \multicolumn{4}{|c|}{ |Table A1 (Continued) } \\
\hline ||Date & $\begin{array}{l}\text { Event/ } \\
\text { Condition }\end{array}$ & Description & Source \\
\hline \begin{tabular}{||l}
$24 \mathrm{Nov}$ \\
1989
\end{tabular} & $\begin{array}{l}\text { Permit } \\
\text { issued by } \\
\text { Common- } \\
\text { wealth of } \\
\text { Pennsyl- } \\
\text { vania }\end{array}$ & $\begin{array}{l}\text { Water Obstruction and Encroachment } \\
\text { Permit issued by Commonwealth of } \\
\text { Pennsylvania, Department of Environmental } \\
\text { Resources, to Safe Harbor Marina, Ltd. }\end{array}$ & $\begin{array}{l}\text { Buffalo District project } \\
\text { notes }\end{array}$ \\
\hline | 8 May 1990 & $\begin{array}{l}\text { Permit } \\
\text { issued by } \\
\text { USACE }\end{array}$ & $\begin{array}{l}\text { Permittee: Safe Harbor Marina, Inc., Permit } \\
\text { no.: } 90-476-1 . \text { Effective date: } \\
8 \text { May } 1990\end{array}$ & $\begin{array}{l}\text { Buffalo District project } \\
\text { notes }\end{array}$ \\
\hline $\begin{array}{l}30 \text { May } \\
1990\end{array}$ & Survey & $\begin{array}{l}\text { Profile lines surveyed at site by Lynn S. } \\
\text { Hofius Land Surveying Services }\end{array}$ & $\begin{array}{l}\text { Hofius facsimile sent to } \\
\text { USACE } \\
(29 \text { Oct 1991) }\end{array}$ \\
\hline \begin{tabular}{|l} 
Spring \\
1990
\end{tabular} & $\begin{array}{l}\text { Breakwater } \\
\text { construction }\end{array}$ & $\begin{array}{l}\text { Construction proved troublesome, and costs } \\
\text { had been underestimated. Marina, docks, } \\
\text { and buildings completed in } 1992 \text { after } \\
\text { expenditure of about } \$ 5,000,000 \text {. After only } \\
\text { two seasons, Safe Harbor Marina, Inc., } \\
\text { ceased operations and abandoned the } \\
\text { leased facilities. Eventually, PA Fish \& Boat } \\
\text { Commission acquired the buildings and } \\
\text { equipment for about } \$ 700,000 \text {. }\end{array}$ & $\begin{array}{l}\text { Briefing paper, PA Fish } \\
\text { \& Boat Commission } \\
\text { (13 Feb 1998) }\end{array}$ \\
\hline ||May 1991 & Bypassing & $\begin{array}{l}\text { Volume unknown. Trucking and grading } \\
\text { documented in photographs }\end{array}$ & $\begin{array}{l}\text { Buffalo District } \\
\text { archives }\end{array}$ \\
\hline Sep 1991 & Bypassing & $\begin{array}{l}\text { Approx } 9,000 \mathrm{yd}^{3} \text { bypassed by truck. From } \\
\text { notation on photographs taken by } \\
\text { J. Peabody, dated } 24 \text { Sep } 1991\end{array}$ & $\begin{array}{l}\text { Buffalo District } \\
\text { archives }\end{array}$ \\
\hline \begin{tabular}{||l}
24 Oct \\
1991
\end{tabular} & Survey & $\begin{array}{l}\text { Profile lines surveyed at site by Lynn S. } \\
\text { Hofius Land Surveying Services }\end{array}$ & $\begin{array}{l}\text { Hofius facsimile sent to } \\
\text { USACE, } 29 \text { Oct } 1991\end{array}$ \\
\hline 4 Dec 1991 & Survey & $\begin{array}{l}\text { Profile lines surveyed at site by Lynn S. } \\
\text { Hofius Land Surveying Services }\end{array}$ & $\begin{array}{l}\text { Hofius letter sent to } \\
\text { USACE, } 5 \text { Dec } 1991\end{array}$ \\
\hline |Dec 1991 & $\begin{array}{l}\text { Sand } \\
\text { accumu- } \\
\text { lation }\end{array}$ & $\begin{array}{l}\text { Littoral material trapped west of breakwater } \\
\text { calculated to be } 13,000 \mathrm{yd}^{3} \text {, based on profile } \\
\text { survey data }\end{array}$ & $\begin{array}{l}\text { Buffalo District } \\
\text { memorandum } \\
12 \text { Dec } 1991\end{array}$ \\
\hline May 1992 & $\begin{array}{l}\text { Proposed jet } \\
\text { pumping }\end{array}$ & $\begin{array}{l}\text { Reviewers at Buffalo District predicted high } \\
\text { probability for failure of jet pump in this } \\
\text { environment. }\end{array}$ & $\begin{array}{l}\text { Buffalo District } \\
\text { memorandum } \\
5 \text { May } 1992\end{array}$ \\
\hline |July 1992 & $\begin{array}{l}\text { Structural } \\
\text { changes } \\
\text { proposed }\end{array}$ & $\begin{array}{l}\text { Proposal to remove shore ends of } \\
\text { breakwaters to allow sediment bypassing. }\end{array}$ & $\begin{array}{l}\text { Buffalo District } \\
\text { memorandum } \\
23 \text { July } 1992\end{array}$ \\
\hline ||6 Aug 1992 & $\begin{array}{l}\text { Suspension } \\
\text { of permit }\end{array}$ & $\begin{array}{l}\text { Letter issued by USACE that Safe Harbor } \\
\text { Marina, Ltd., was not in compliance with } \\
\text { Permit } 90-476-1 .\end{array}$ & $\begin{array}{l}\text { Buffalo District project } \\
\text { notes }\end{array}$ \\
\hline $\mid \begin{array}{l}30 \mathrm{Nov} \\
1992\end{array}$ & $\begin{array}{l}\text { Permit } \\
\text { modification }\end{array}$ & $\begin{array}{l}\text { USACE approved modification to allow } \\
\text { bypassing with hydraulic pump system }\end{array}$ & $\begin{array}{l}\text { Buffalo District project } \\
\text { notes }\end{array}$ \\
\hline
\end{tabular}




\begin{tabular}{|c|c|c|c|}
\hline \multicolumn{4}{|c|}{ Table A1 (Continued) } \\
\hline ||Date & $\begin{array}{l}\text { Event/ } \\
\text { Condition }\end{array}$ & Description & Source \\
\hline \begin{tabular}{||l} 
Jan-Mar \\
1993
\end{tabular} & $\begin{array}{l}\text { Jet pump } \\
\text { bypass trial }\end{array}$ & $\begin{array}{l}\text { Safe Harbor Marina, Inc., attempted } \\
\text { pumping operation using } 4 \text {-in. Pekor jet } \\
\text { pump. Experiment unsuccessful because } \\
\text { pipe clogged with cobbles, shale plates, and } \\
\text { debris. Small crater size required frequent } \\
\text { movement of intake. Lines froze in cold } \\
\text { weather. Homeowners complained at } \\
\text { operators because of fear of crater. } \\
\text { Hydraulic bypassing achieved: } \\
\text { Jan: } 850 \mathrm{yd}^{3} \\
\text { Feb: } 1,650 \mathrm{yd}^{3} \\
\text { Mar: } 666 \mathrm{yd}^{3}\end{array}$ & $\begin{array}{l}\text { Misc. Buffalo District } \\
\text { memoranda, Jan - Feb } \\
1993\end{array}$ \\
\hline Apr 1993 & Bypassing & $\begin{array}{l}979 \mathrm{yd}^{3} \text { sand, } 204 \mathrm{yd}^{3} \text { cobble bypassed } \\
\text { mechanically. }\end{array}$ & $\begin{array}{l}\text { Buffalo District project } \\
\text { notes }\end{array}$ \\
\hline || 7 July 1993 & $\begin{array}{l}\text { Permit } \\
\text { transferred }\end{array}$ & $\begin{array}{l}\text { Safe Harbor Marina, Ltd., transferred Permit } \\
90-476-1 \text { to PA Fish and Boat Commission. } \\
\text { Thereby, PFBC assumed responsibility for } \\
\text { permit compliance. }\end{array}$ & $\begin{array}{l}\text { Buffalo District project } \\
\text { notes }\end{array}$ \\
\hline \begin{tabular}{|l}
18 Oct -17 \\
Nov 1993
\end{tabular} & Fill & $\begin{array}{l}\text { Commercial dredger unable to begin work. } \\
\text { Therefore, } \approx 12,000 \mathrm{yd}^{3} \text { of sand and cobble } \\
\text { purchased from upland source and placed } \\
\text { on beach east of marina. Cost of materials } \\
\text { and transportation: } \$ 95,547 \text {. }\end{array}$ & $\begin{array}{l}\text { PA Fish \& Boat } \\
\text { Commission letter sent } \\
\text { to USACE, } 10 \text { Nov \& } \\
20 \text { Dec } 1993\end{array}$ \\
\hline | 4 Nov 1993 & Bankruptcy & $\begin{array}{l}\text { Safe Harbor Marina, Ltd., formally notified } \\
\text { Fish \& Boat Commission that it could no } \\
\text { longer continue to operate the marina }\end{array}$ & $\begin{array}{l}\text { PA Fish \& Boat } \\
\text { Commission letter sent } \\
\text { to USACE, } 10 \text { Nov } \\
1993\end{array}$ \\
\hline \begin{tabular}{|l} 
Spring \\
1994
\end{tabular} & $\begin{array}{l}\text { Marina } \\
\text { dredging }\end{array}$ & $\begin{array}{l}\text { Wood, leaves, organic debris removed from } \\
\text { the marina basin. Original plan was to place } \\
\text { the material on the east beach, but due to } \\
\text { the high organic content, the material was } \\
\text { instead placed on the back of the PFBC lot } \\
\text { to dewater. Volume } 6-10,000 \mathrm{yd}^{3} \text {. The dry } \\
\text { soil was later given to local farmers to use } \\
\text { as fertilizer. }\end{array}$ & $\begin{array}{l}\text { Personal } \\
\text { Communication, } \\
\text { Mr. James Young, PA } \\
\text { Fish \& Boat } \\
\text { Commission } \\
1 \text { Mar } 2000\end{array}$ \\
\hline \begin{tabular}{|l} 
Spring \\
1994
\end{tabular} & $\begin{array}{l}\text { Marina } \\
\text { mouth } \\
\text { dredging }\end{array}$ & $\begin{array}{l}\text { Mostly logs, sticks, and organic material } \\
\text { removed (resembled a beaver dam). Part of } \\
\text { marina cleaning operation }\end{array}$ & $\begin{array}{l}\text { Personal } \\
\text { Communication, Mr. } \\
\text { Gary Moore, PA Fish \& } \\
\text { Boat Commission } \\
1 \text { Mar } 2000\end{array}$ \\
\hline |June 1994 & Report & $\begin{array}{l}\text { Well documented and illustrated survey } \\
\text { report sponsored by PA Fish \& Boat Comm.: } \\
\text { "Coastal Environmental Investigation of the } \\
\text { Safe Harbor Marina, North East Township, } \\
\text { North East, PA," by K. Taylor and M. R. } \\
\text { Buyce. }\end{array}$ & $\begin{array}{l}\text { Copy provided by PA } \\
\text { Fish \& Boat } \\
\text { Commission }\end{array}$ \\
\hline ||June 1994 & Fill & $\begin{array}{l}5,015 \mathrm{yd}^{3} \text { sand and cobble from upland } \\
\text { source. }\end{array}$ & $\begin{array}{l}\text { PA Fish \& Boat } \\
\text { Commission letter sent } \\
\text { to USACE, } 27 \text { June } \\
1994\end{array}$ \\
\hline
\end{tabular}




\begin{tabular}{|c|c|c|c|}
\hline \multicolumn{4}{|c|}{ |Table A1 (Continued) } \\
\hline ||Date & $\begin{array}{l}\text { Event/ } \\
\text { Condition }\end{array}$ & Description & Source \\
\hline || 7 Oct 1994 & $\begin{array}{l}\text { Lakefront } \\
\text { property }\end{array}$ & $\begin{array}{l}4.9 \text { acres of property west of the marina with } \\
50 \mathrm{~m} \text { of lake frontage purchased by State of } \\
\text { PA for } \$ 175,000 \text { to allow beach access for } \\
\text { bypassing operations. }\end{array}$ & $\begin{array}{l}\text { Briefing paper, PA Fish } \\
\text { \& Boat Commission, } \\
13 \text { Feb } 1998\end{array}$ \\
\hline \begin{tabular}{|l}
$11-16$ Nov \\
1994
\end{tabular} & Bypassing & $\begin{array}{l}9,141 \text { yd }^{3} \text { moved by truck by PA Fish } \& \text { Boat } \\
\text { Comm. Lack of cobble noted on beach, } \\
\text { bypassed material was almost purely sand. }\end{array}$ & $\begin{array}{l}\text { PA Fish \& Boat } \\
\text { Commission letter } \\
\text { report (Mr. James } \\
\text { Waite, } 22 \text { Nov 1994) }\end{array}$ \\
\hline $\mid \begin{array}{l}10-20 \mathrm{Apr} \\
1995\end{array}$ & Bypassing & $\begin{array}{l}8,428 \text { yd }^{3} \text { moved by truck by PA Fish \& Boat } \\
\text { Comm. }\end{array}$ & $\begin{array}{l}\text { PA Fish \& Boat } \\
\text { Commission letter } \\
\text { report (Mr. James } \\
\text { Waite, } 26 \text { Apr 1995) }\end{array}$ \\
\hline \begin{tabular}{|l}
23 Oct -2 \\
Nov 1995
\end{tabular} & Bypassing & $\begin{array}{l}\text { 9,296 yd }{ }^{3} \text { moved by truck by PA Fish \& Boat } \\
\text { Comm. }\end{array}$ & $\begin{array}{l}\text { PA Fish \& Boat } \\
\text { Commission letter } \\
\text { report (Mr. James } \\
\text { Waite, } 6 \text { Nov 1995) }\end{array}$ \\
\hline \begin{tabular}{|l}
$6-20$ Jun \\
1996
\end{tabular} & Bypassing & $\begin{array}{l}8,148 \text { yd }^{3} \text { moved by truck by PA Fish \& Boat } \\
\text { Comm. }\end{array}$ & $\begin{array}{l}\text { PA Fish \& Boat } \\
\text { Commission letter } \\
\text { report (Mr. James } \\
\text { Waite, } 21 \text { Jun 1996) }\end{array}$ \\
\hline \begin{tabular}{|l}
28 Oct -20 \\
Nov 1996
\end{tabular} & Bypassing & $\begin{array}{l}12,710 \mathrm{yd}^{3} \text { moved by truck by PA Fish \& } \\
\text { Boat Comm. }\end{array}$ & $\begin{array}{l}\text { PA Fish \& Boat } \\
\text { Commission letter } \\
\text { report (Mr. James } \\
\text { Waite, } 21 \text { Nov 1996) }\end{array}$ \\
\hline | 1 Feb 1997 & Report & $\begin{array}{l}\text { Survey report, "Erosion and Accretion at } \\
\text { Safe Harbor Marina," prepared by Galvin, } \\
\text { sponsored by property owners. Recom- } \\
\text { mended material be bypassed at rate of } \\
16,000 \mathrm{yd}^{3} / \text { year. }\end{array}$ & $\begin{array}{l}\text { Buffalo District } \\
\text { archives }\end{array}$ \\
\hline \begin{tabular}{||l}
13 May - 18 \\
Jun 1997
\end{tabular} & Bypassing & $\begin{array}{l}\text { 6,258 } \mathrm{yd}^{3} \text { moved by truck by PA Fish \& Boat } \\
\text { Comm. }\end{array}$ & $\begin{array}{l}\text { PA Fish \& Boat } \\
\text { Commission letter } \\
\text { report (Mr. James } \\
\text { Waite, } 25 \text { Jun 1997) } \\
\end{array}$ \\
\hline \begin{tabular}{|l}
$3-18$ Nov \\
1997
\end{tabular} & Bypassing & $\begin{array}{l}\text { 6,804 } \text { yd }^{3} \text { moved by truck by PA Fish \& Boat } \\
\text { Comm. }\end{array}$ & $\begin{array}{l}\text { PA Fish \& Boat } \\
\text { Commission letter } \\
\text { report (Mr. James } \\
\text { Waite, } 21 \text { Nov 1997) }\end{array}$ \\
\hline $\mid \begin{array}{l}8 \text { Apr }-6 \\
\text { May } 1998\end{array}$ & Bypassing & $\begin{array}{l}10,164 \text { yd }^{3} \text { moved by truck by PA Fish \& } \\
\text { Boat Comm. }\end{array}$ & $\begin{array}{l}\text { PA Fish \& Boat } \\
\text { Commission letter } \\
\text { report (Mr. James } \\
\text { Waite, } 11 \text { May 1998) }\end{array}$ \\
\hline $\begin{array}{l}5 \text { June } \\
1998\end{array}$ & Report & $\begin{array}{l}\text { Survey report, "Long Range Action Plan, } \\
\text { North East Marina, North East, PA," } \\
\text { prepared by Offshore \& Coastal } \\
\text { Technologies, Inc., sponsored by PA Fish \& } \\
\text { Boat Comm. }\end{array}$ & $\begin{array}{l}\text { PA Fish \& Boat } \\
\text { Commission archives }\end{array}$ \\
\hline \begin{tabular}{|l}
$2-19$ Nov \\
1998
\end{tabular} & Bypassing & $\begin{array}{l}13,552 \mathrm{yd}^{3} \text { moved by truck by PA Fish \& } \\
\text { Boat Comm. }\end{array}$ & $\begin{array}{l}\text { PA Fish \& Boat } \\
\text { Commission letter } \\
\text { report (Mr. James } \\
\text { Young, } 4 \text { Dec 1998) }\end{array}$ \\
\hline
\end{tabular}




\begin{tabular}{|c|c|c|c|}
\hline \multicolumn{4}{|c|}{ Table A1 (Concluded) } \\
\hline Date & $\begin{array}{l}\text { Event/ } \\
\text { Condition }\end{array}$ & Description & Source \\
\hline $\begin{array}{l}\text { Apr-May } \\
1999\end{array}$ & Bypassing & $\begin{array}{l}10,113 \mathrm{yd}^{3} \text { moved by truck by PA Fish } \& \\
\text { Boat Comm. }\end{array}$ & $\begin{array}{l}\text { Personal } \\
\text { Communication, } \\
\text { Mr. James Young, PA } \\
\text { Fish \& Boat } \\
\text { Commission, } \\
29 \text { Dec } 1999\end{array}$ \\
\hline \begin{tabular}{|l} 
Apr-May \\
1999
\end{tabular} & $\begin{array}{l}\text { Marina } \\
\text { mouth } \\
\text { dredging }\end{array}$ & $\begin{array}{l}\text { Mostly sticks, and organic material removed, } \\
\text { but sandier than in } 1994 \text {. Approx. } 8,000 \mathrm{yd}^{3} \\
\text { placed in parking lot to dewater. }\end{array}$ & $\begin{array}{l}\text { Personal } \\
\text { Communication, Mr. } \\
\text { Jim Young, PA Fish \& } \\
\text { Boat Commission, } \\
1 \text { Mar } 2000\end{array}$ \\
\hline Nov 1999 & Bypassing & $\begin{array}{l}5,152 \mathrm{yd}^{3} \text { moved by truck by PA Fish \& Boat } \\
\text { Comm. ( } 4116 \mathrm{yd}^{3} \text { placed on beach, } 1036 \\
\mathrm{yd}^{3} \text { used for road construction). }\end{array}$ & $\begin{array}{l}\text { PA Fish \& Boat } \\
\text { Commission letter } \\
\text { report (Mr. James } \\
\text { Young, } 19 \text { Jan 2000) }\end{array}$ \\
\hline $\begin{array}{l}\text { April } 17- \\
\text { May } 30 \\
2000\end{array}$ & Bypassing & $\begin{array}{l}10,276 \mathrm{yd}^{3} \text { moved by truck by PA Fish \& } \\
\text { Boat Comm. }\end{array}$ & $\begin{array}{l}\text { PA Fish and Boat } \\
\text { Commission letter } \\
\text { report (Mr. Robert } \\
\text { Fishburn, } 6 \text { Jun 2000) }\end{array}$ \\
\hline $\begin{array}{l}\text { Oct-Nov } \\
2000\end{array}$ & Bypassing & $\begin{array}{l}10,400 \mathrm{yd}^{3} \text { moved by truck by PA Fish } \& \\
\text { Boat Comm. }\end{array}$ & $\begin{array}{l}\text { PA Fish \& Boat } \\
\text { Commission (Personal } \\
\text { Communication, } \\
\text { Mr. James Young, } \\
21 \text { Nov 2000) }\end{array}$ \\
\hline
\end{tabular}




\section{Appendix B Inventory of Site Photographs}

Table B1 lists all known aerial photographs at North East Marina. Various ground-level photographs are also listed. Vertical aerial images have been scanned and are reproduced in the following pages. The images have been mosaicked but have not been orthorectified for mapping purposes.

\begin{tabular}{|c|c|c|c|c|}
\hline \multicolumn{5}{|c|}{$\begin{array}{l}\text { Table B1 } \\
\text { Index of Photographs, North East Marina, Erie County, PA }\end{array}$} \\
\hline Date & $\begin{array}{l}\text { Type }(C= \\
\text { color; } P= \\
\text { photocopy; } \\
\text { BW = black } \\
\text { and white) }\end{array}$ & Coverage & Notes & Source \\
\hline 2 Oct 1938 & $\begin{array}{l}\text { Vertical aerial } \\
\text { BW }\end{array}$ & $\begin{array}{l}\text { Twentymile } \\
\text { Creek }\end{array}$ & & $\begin{array}{l}\text { Buffalo District } \\
\text { (from National } \\
\text { Archives, record } \\
\text { group No. 146) }\end{array}$ \\
\hline 1974 & $\begin{array}{l}\text { Vertical aerial } \\
\text { BW 1:4,800 }\end{array}$ & $\begin{array}{l}\text { Headland to } \\
\text { Twentymile } \\
\text { Creek }\end{array}$ & $\begin{array}{l}\text { Premarina. No. 5462-26- } \\
\text { 965, 967, 969. Tag on back: } \\
\text { LE-PA-INDEX 33-1974 }\end{array}$ & Buffalo District \\
\hline 1974 & $\begin{array}{l}\text { Vertical aerial } \\
\text { C } 1: 4,800\end{array}$ & $\begin{array}{l}\text { Headland to } \\
\text { Twentymile } \\
\text { Creek }\end{array}$ & $\begin{array}{l}\text { Premarina. No. } 34-144, \\
146,148\end{array}$ & Buffalo District \\
\hline $\begin{array}{l}16 \text { June } \\
1968\end{array}$ & $\begin{array}{l}\text { Hand-held BW } \\
\text { P }\end{array}$ & Marina area & $\begin{array}{l}\text { Former boat ramp. Cobble - } \\
\text { gravel beach, no sand. }\end{array}$ & Buffalo District \\
\hline $\begin{array}{l}21 \text { Aug } \\
1984\end{array}$ & $\begin{array}{l}\text { Vertical aerial } \\
\text { BW 1:4,800 }\end{array}$ & $\begin{array}{l}\text { Headland to } \\
\text { Twentymile } \\
\text { Creek }\end{array}$ & $\begin{array}{l}\text { Premarina. No. } 351 \text { 119-34, } \\
36,38\end{array}$ & \\
\hline $\begin{array}{l}10 \text { July } \\
1986\end{array}$ & $\begin{array}{l}\text { Vertical aerial } \\
\text { BW 1:4,800 }\end{array}$ & $\begin{array}{l}\text { Headland to } \\
\text { Twentymile } \\
\text { Creek }\end{array}$ & $\begin{array}{l}\text { Premarina. No. } 111 \text { 06, 08, } \\
\text { and } 10\end{array}$ & Buffalo District \\
\hline \begin{tabular}{|l}
$17 \mathrm{Nov}$ \\
1986
\end{tabular} & Hand-held CP & West beach & Cobble beach, no sand & Buffalo District \\
\hline
\end{tabular}




\begin{tabular}{|c|c|c|c|c|}
\hline \multicolumn{5}{|c|}{ Table B1 (Continued) } \\
\hline Date & $\begin{array}{l}\text { Type }(C= \\
\text { color; } P= \\
\text { photocopy; } \\
\text { BW = black } \\
\text { and white) }\end{array}$ & Coverage & Notes & Source \\
\hline $\begin{array}{l}24 \text { April } \\
1995\end{array}$ & $\begin{array}{l}\text { Hand-held } \\
\text { aerial CP }\end{array}$ & $\begin{array}{l}\text { Marina and } \\
\text { Lake Erie coast }\end{array}$ & Waves from $\mathrm{N}$ to $\mathrm{NE}$ & $\begin{array}{l}\text { PA Fish and } \\
\text { Boat } \\
\text { Commission }\end{array}$ \\
\hline May 1995 & $\begin{array}{l}\text { Hand-held } \\
\text { aerial CP }\end{array}$ & Marina area & Post sand replenishment & $\begin{array}{l}\text { PA Fish and } \\
\text { Boat } \\
\text { Commission }\end{array}$ \\
\hline 26 Oct 1995 & Hand-held CP & $\begin{array}{l}\text { East side } \\
\text { beaches }\end{array}$ & Views as sand being graded & $\begin{array}{l}\text { PA Fish and } \\
\text { Boat } \\
\text { Commission }\end{array}$ \\
\hline 5 June 1996 & $\begin{array}{l}\text { Hand-held } \\
\text { aerial CP }\end{array}$ & Marina & 4 images & $\begin{array}{l}\text { PA Fish and } \\
\text { Boat } \\
\text { Commission }\end{array}$ \\
\hline 12 Oct 1996 & Hand-held CP & $\begin{array}{l}\text { West side } \\
\text { beaches }\end{array}$ & Views of beach being graded & $\begin{array}{l}\text { PA Fish and } \\
\text { Boat } \\
\text { Commission }\end{array}$ \\
\hline $\begin{array}{l}\text { 3-4 April } \\
\text { 1997 }\end{array}$ & Hand-held CP & $\begin{array}{l}\text { East and west } \\
\text { side beaches }\end{array}$ & Much driftwood on west side & $\begin{array}{l}\text { PA Fish and } \\
\text { Boat } \\
\text { Commission }\end{array}$ \\
\hline 4 June 1997 & Hand-held CP & \begin{tabular}{|l} 
East and west \\
walls \& beaches
\end{tabular} & & \\
\hline 8 Sep 1997 & Hand-held CP & $\begin{array}{l}\text { East and west } \\
\text { beaches }\end{array}$ & $\begin{array}{l}\text { Recently-placed sand at } \\
\text { base of east bluffs }\end{array}$ & $\begin{array}{l}\text { PA Fish and } \\
\text { Boat } \\
\text { Commission }\end{array}$ \\
\hline 5 Nov 1997 & Hand-held CP & $\begin{array}{l}\text { East and west } \\
\text { sand beaches }\end{array}$ & Sand being moved by trucks & $\begin{array}{l}\text { PA Fish and } \\
\text { Boat } \\
\text { Commission }\end{array}$ \\
\hline $\begin{array}{l}10 \text { Feb } \\
1998\end{array}$ & Hand-held CP & $\begin{array}{l}\text { East and west } \\
\text { beaches }\end{array}$ & $\begin{array}{l}\text { Conditions. Sand placed in } \\
\text { Nov. } 1997 \text { gone. }\end{array}$ & $\begin{array}{l}\text { PA Fish and } \\
\text { Boat } \\
\text { Commission }\end{array}$ \\
\hline $\begin{array}{l}29 \text { April }-6 \\
\text { May } 1998\end{array}$ & Hand-held CP & $\begin{array}{l}\text { East and west } \\
\text { beaches }\end{array}$ & $\begin{array}{l}\text { Recently-placed sand east } \\
\text { beach }\end{array}$ & $\begin{array}{l}\text { PA Fish and } \\
\text { Boat } \\
\text { Commission }\end{array}$ \\
\hline 7 May 1998 & $\begin{array}{l}\text { Hand-held } \\
\text { aerial CP }\end{array}$ & $\begin{array}{l}\text { East and west } \\
\text { beaches }\end{array}$ & $\begin{array}{l}\text { Recently-placed sand east } \\
\text { beach }\end{array}$ & $\begin{array}{l}\text { PA Fish and } \\
\text { Boat } \\
\text { Commission }\end{array}$ \\
\hline $\begin{array}{l}20 \text { Aug } \\
1998\end{array}$ & Hand-held CP & $\begin{array}{l}\text { East and west } \\
\text { beaches }\end{array}$ & $\begin{array}{l}\text { Sand placed in May still } \\
\text { present on east beach }\end{array}$ & $\begin{array}{l}\text { PA Fish and } \\
\text { Boat } \\
\text { Commission }\end{array}$ \\
\hline $\begin{array}{l}16 \text { Sep } \\
1998\end{array}$ & Hand-held CP & Marina area & $\begin{array}{l}\text { Wind and waves from east } \\
\text { side }\end{array}$ & $\begin{array}{l}\text { PA Fish and } \\
\text { Boat } \\
\text { Commission }\end{array}$ \\
\hline 27 Oct 1998 & Hand-held CP & West beach & Sand pile being formed & Buffalo District \\
\hline
\end{tabular}




\begin{tabular}{|c|c|c|c|c|}
\hline \multicolumn{5}{|c|}{ Table B1 (Concluded) } \\
\hline Date & $\begin{array}{l}\text { Type }(C= \\
\text { color; } P= \\
\text { photocopy; } \\
\text { BW = black } \\
\text { and white) }\end{array}$ & Coverage & Notes & Source \\
\hline $\begin{array}{l}5,12,13 \\
17 \text { Nov } \\
1998\end{array}$ & Hand-held C & Marina area & $\begin{array}{l}\text { Conditions during sand } \\
\text { bypassing }\end{array}$ & $\begin{array}{l}\text { PA Fish and } \\
\text { Boat } \\
\text { Commission }\end{array}$ \\
\hline 29 Jan 1999 & Hand-held C & Marina area & $\begin{array}{l}\text { Winter condition, post- } \\
\text { bypassing, lake not frozen }\end{array}$ & $\begin{array}{l}\text { PA Fish and } \\
\text { Boat } \\
\text { Commission }\end{array}$ \\
\hline 28 Apr 1999 & $\begin{array}{l}\text { Vertical aerial } \\
\text { BW }\end{array}$ & $\begin{array}{l}\text { Marina and } \\
\text { coast }\end{array}$ & NE waves, $1: 2400,14$ frames & Buffalo District \\
\hline 27 Jul 1999 & $\begin{array}{l}\text { Vertical aerial } \\
\text { C }\end{array}$ & $\begin{array}{l}\text { Marina and } \\
\text { coast }\end{array}$ & $\begin{array}{l}\text { Low } W \text { to NW waves, } \\
1: 2400,13 \text { frames flown by } \\
\text { Aerocon Photogrammetric } \\
\text { Services }\end{array}$ & Buffalo District \\
\hline 15 Oct 1999 & $\begin{array}{l}\text { Vertical aerial } \\
\text { BW }\end{array}$ & $\begin{array}{l}\text { Marina and } \\
\text { coast }\end{array}$ & $\begin{array}{l}\text { No waves, very clear water, } \\
1: 2400,14 \text { frames flown by } \\
\text { Aerocon Photogrammetric } \\
\text { Services }\end{array}$ & Buffalo District \\
\hline
\end{tabular}




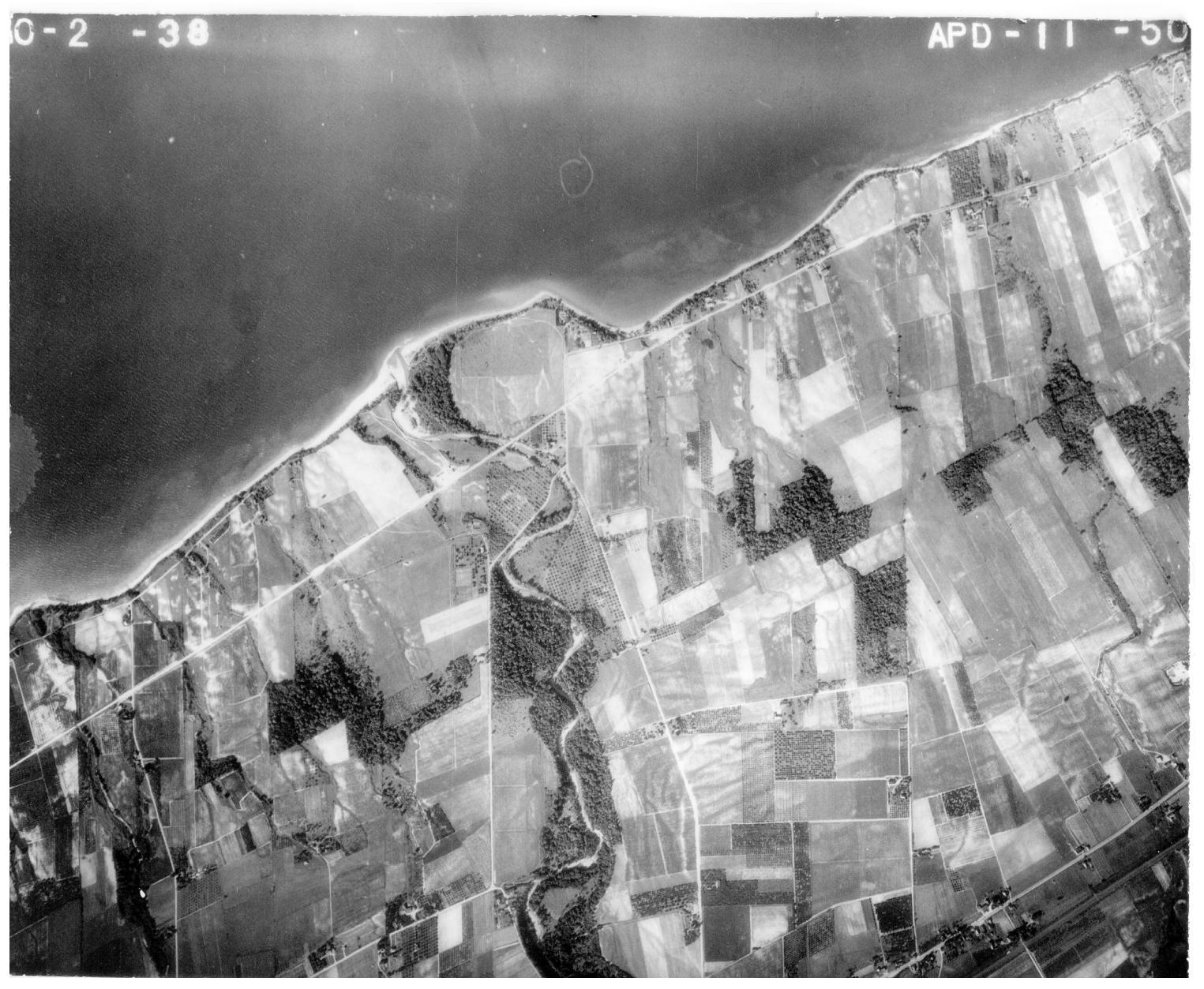

Figure B1. 1939 (National Archives) 


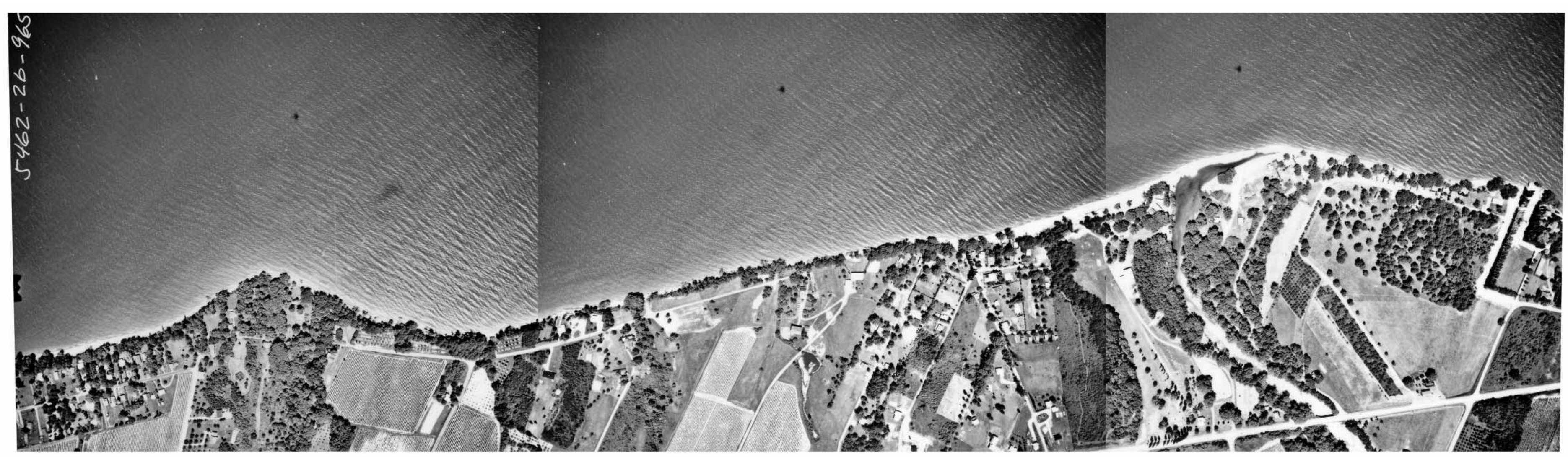

Figure B2. 1974 (exact data unknown) 


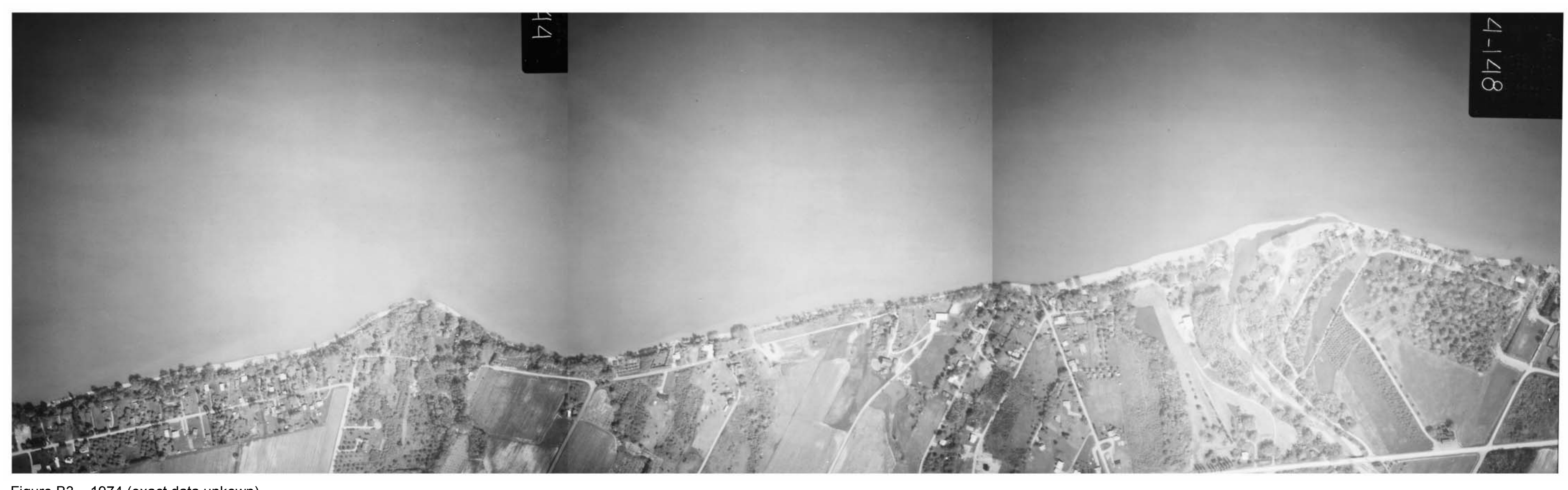

Figure B3. 1974 (exact data unkown) 


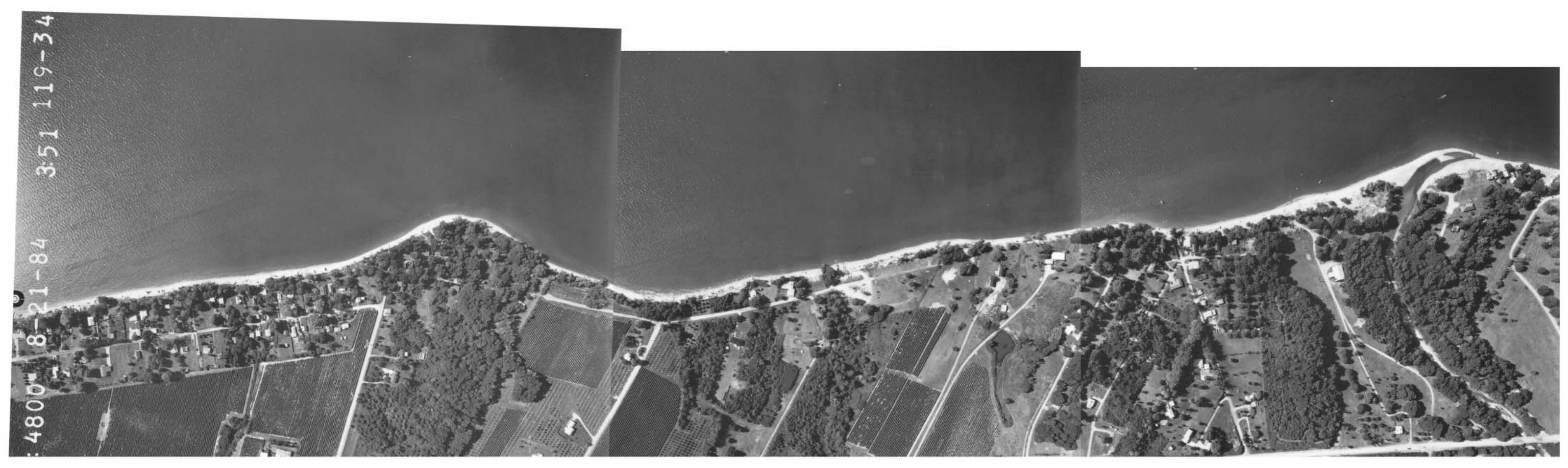

Figure B4. August 21, 1984 (Buffalo District) 


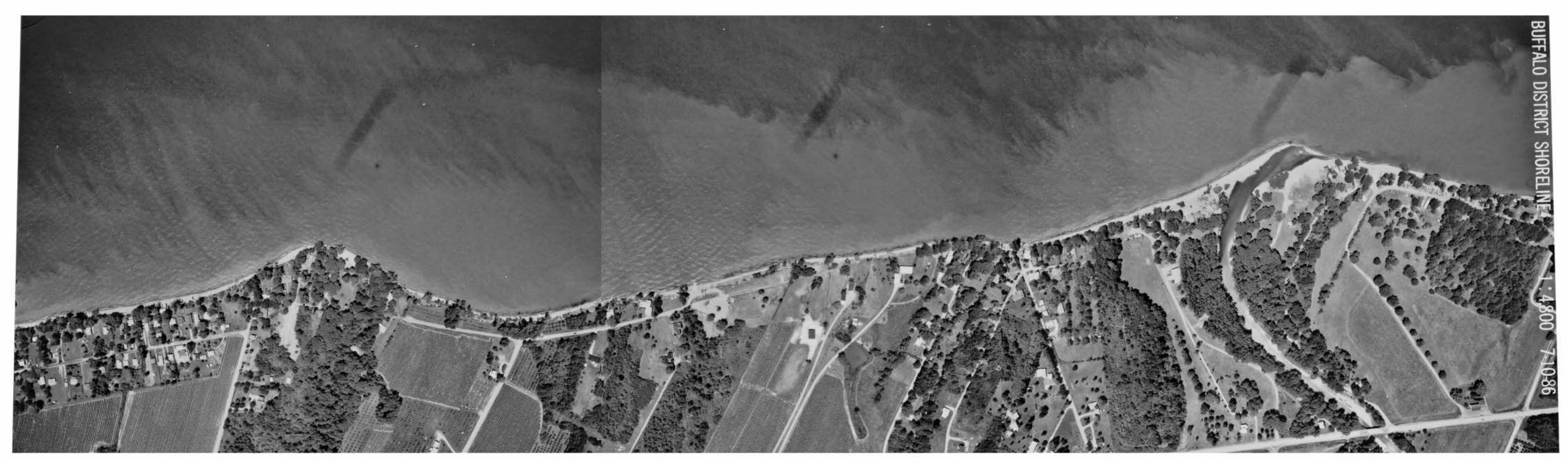

Figure B5. July 10, 1986 (U.S. Geological Survey) 


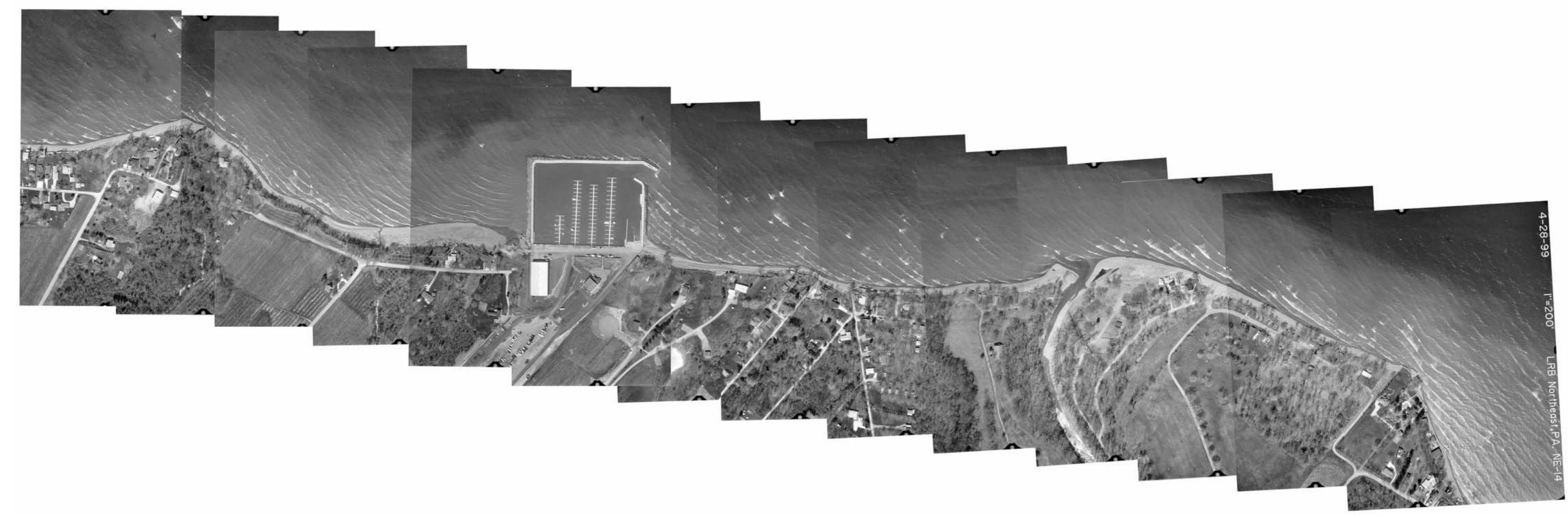

Figure B6. April 28, 1999 (Buffalo District) 


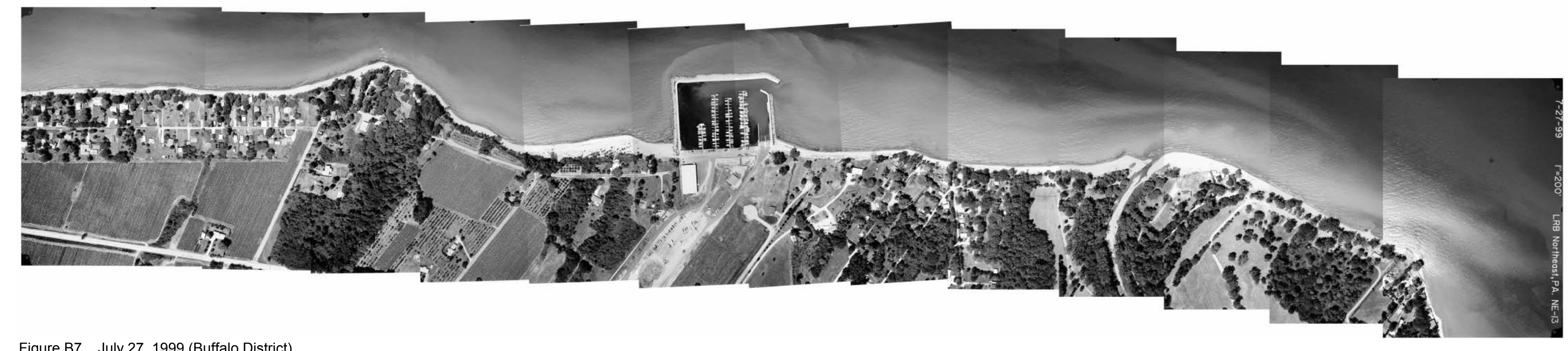

Figure B7. July 27, 1999 (Buffalo District) 


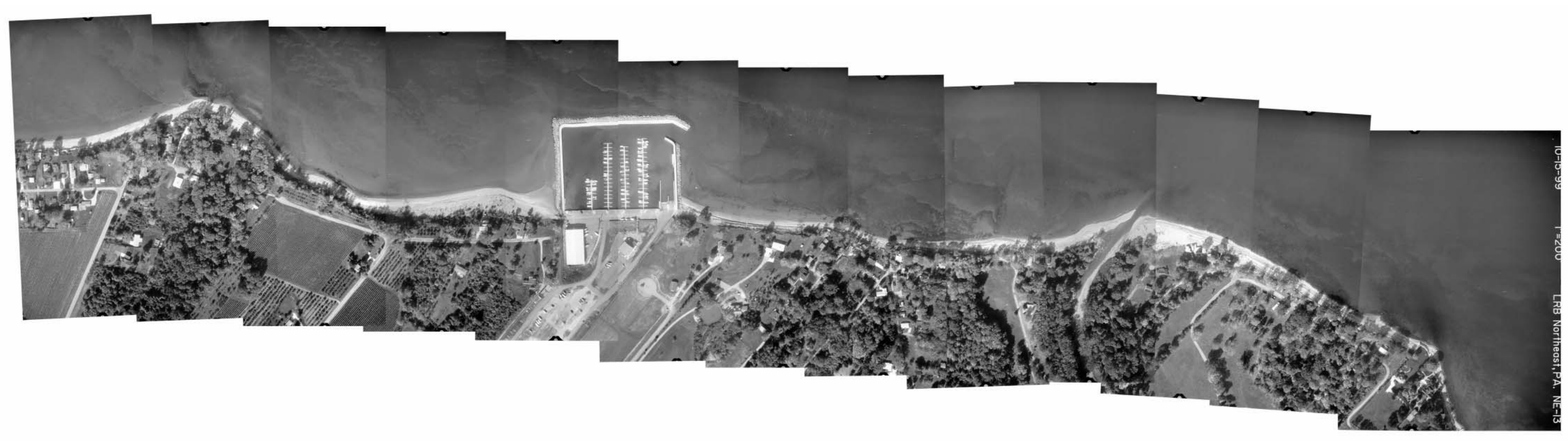

Figure B8. October 15, 1999 (Buffalo District) 


\section{Appendix C Inventory of Topographic Profile Surveys}

Table $\mathrm{C} 1$ is an inventory of all known cross-shore profiles surveys for the North East Marina vicinity. Plots are reproduced on the following pages, with elevations referenced to IGLD 1985, units in feet.

\begin{tabular}{|c|c|c|}
\hline \multicolumn{3}{|c|}{$\begin{array}{l}\text { Table C1 } \\
\text { Profile and Topographic Surveys, North East Marina, Erie County, } \\
\text { PA }\end{array}$} \\
\hline Date & Coverage & Contractor \\
\hline 30 May 1990 & $\begin{array}{l}\text { W025, W075, W150, W225, W300 } \\
\text { E675, E750, E825, E900, E975, E1050 }\end{array}$ & Hofius $^{1}$ \\
\hline 24 Oct 1991 & $\begin{array}{l}\text { W025, W075, W150, W225, W300 } \\
\text { E675, E750, E825, E900, E975, E1050 }\end{array}$ & Hofius $^{1}$ \\
\hline 4 Dec 1991 & $\begin{array}{l}\text { W025, W075, W150, W225, W300 } \\
\text { E075, E150, E225, E300, E375, E450, E525, E600, E675, } \\
\text { E675, E750, E825, E900, E975, E1050, E1125 } \\
\text { (Note: some of these profiles may contain duplicate data } \\
\text { from } 24 \text { October surveys). }\end{array}$ & Hofius $^{1}$ \\
\hline $\begin{array}{l}22-24 \text { Sep } \\
1999\end{array}$ & $\begin{array}{l}\text { W025, W075, W150, W225, W300, W400, W500, W600, } \\
\text { W700, W800, W900, W1000, W1100, W1200 } \\
\text { E750, E825, E900, E975, E1050, E1125, E1200, E1300, } \\
\text { E1400, E1500, E1600, E1700, E1800, E1900, E2000, } \\
\text { E2100, E2200, E2300, E3400, E2500, E2600, E2700, } \\
\text { E2800, E2900, E3000, E3100, E3200 }\end{array}$ & GRW Aerial $^{2}$ \\
\hline \multicolumn{3}{|c|}{$\begin{array}{l}\text { Lynn S. Hofius, Benchmark Surveying, P.O. Box 803, Waterford, PA } 16441 \text { (tel. } 814796 \text { 2053). } \\
\text { Digital files recreated from paper copies of data sheets. } \\
2 \text { GRW Aerial Surveys, Inc., 801 Corporate Drive, Lexington, KY } 40503 \text { (tel. } 606223 \text { 3999). Data } \\
\text { supplied digitally as ASCII X-Y-Z files, Pennsylvania State Plane North Zone coordinate system. }\end{array}$} \\
\hline
\end{tabular}



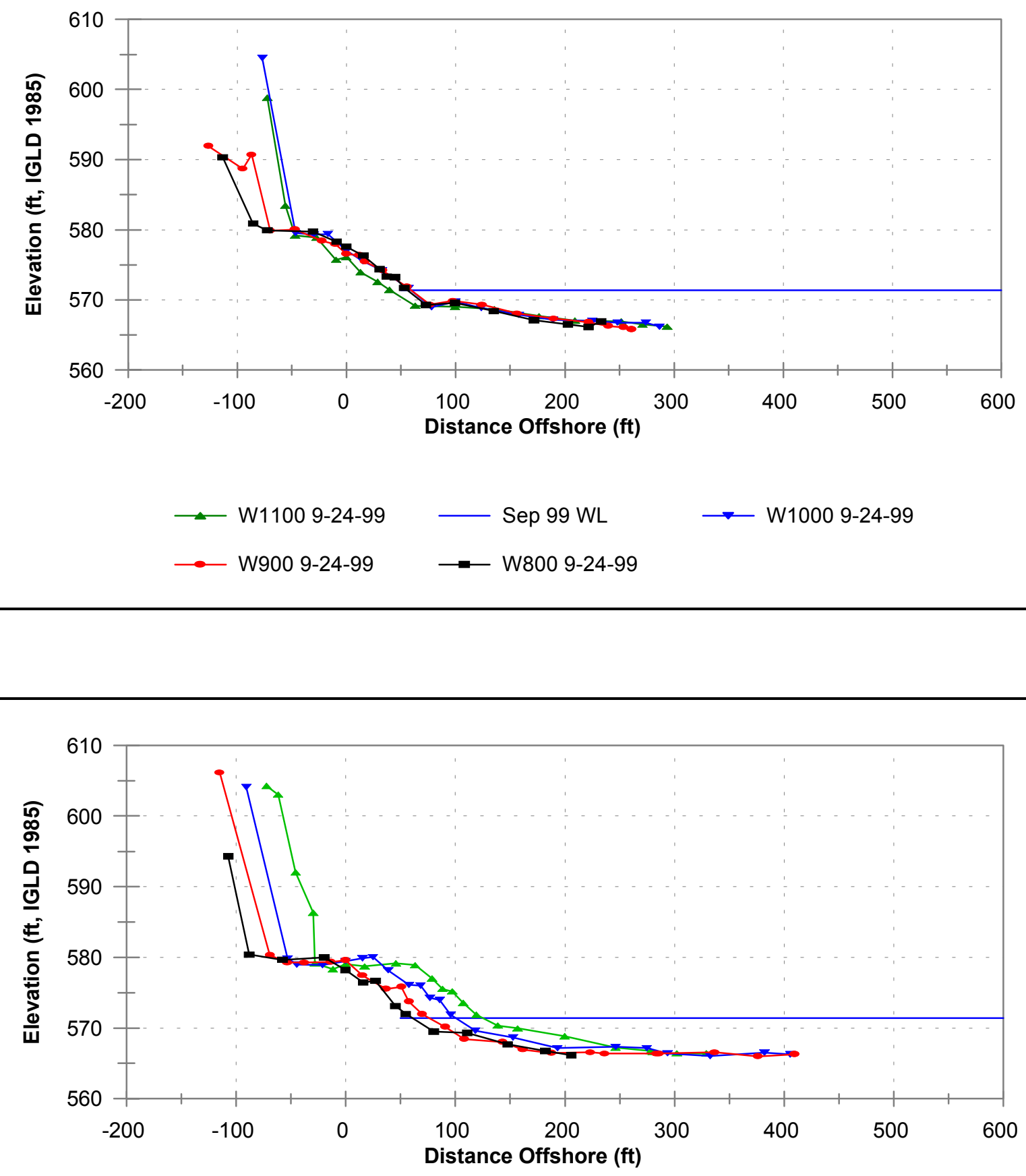

- Sep 99 WL $\longrightarrow$ W400 9-24-99 $\longrightarrow$ W500 9-24-99

$\because W 600$ 9-24-99 $\quad \longrightarrow$ W700 9-24-99 


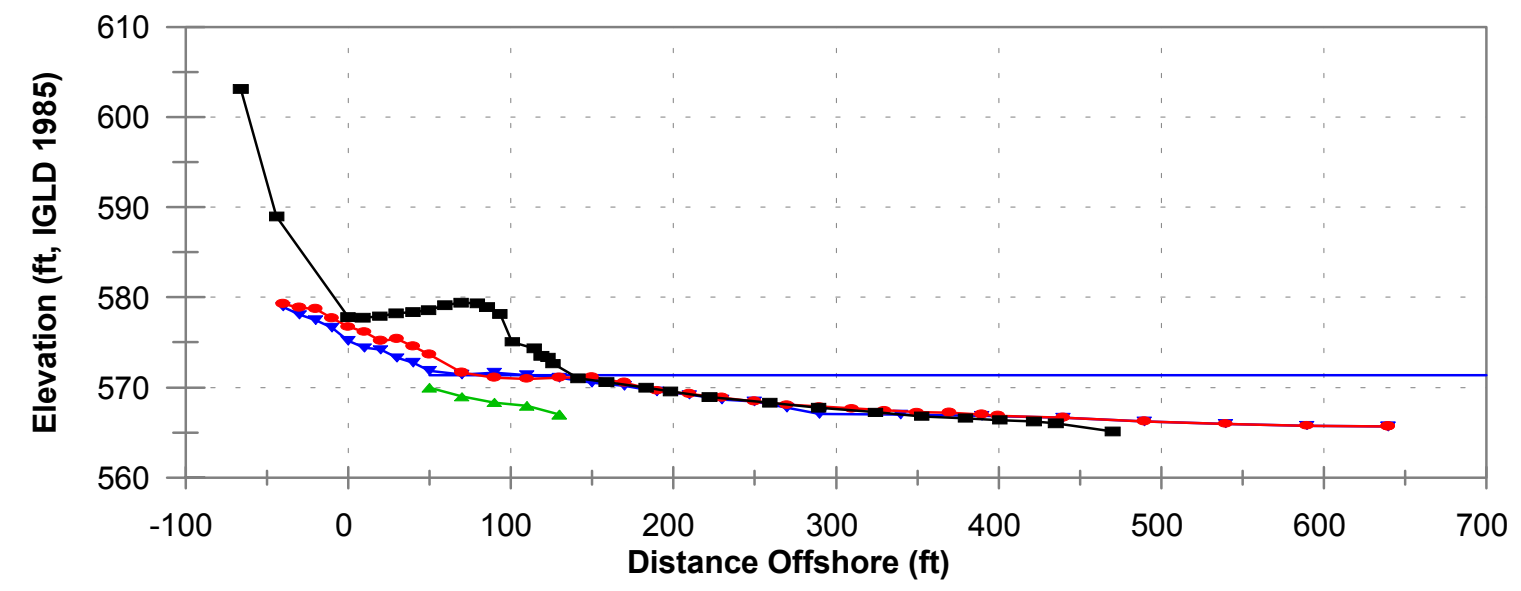

— Sep $99 \mathrm{WL}$

—W300 5-30-90 Pre-project

$\longrightarrow$ W300 12-4-91

$\multimap$ W300 9-16-92

$=$ W300 9-24-99

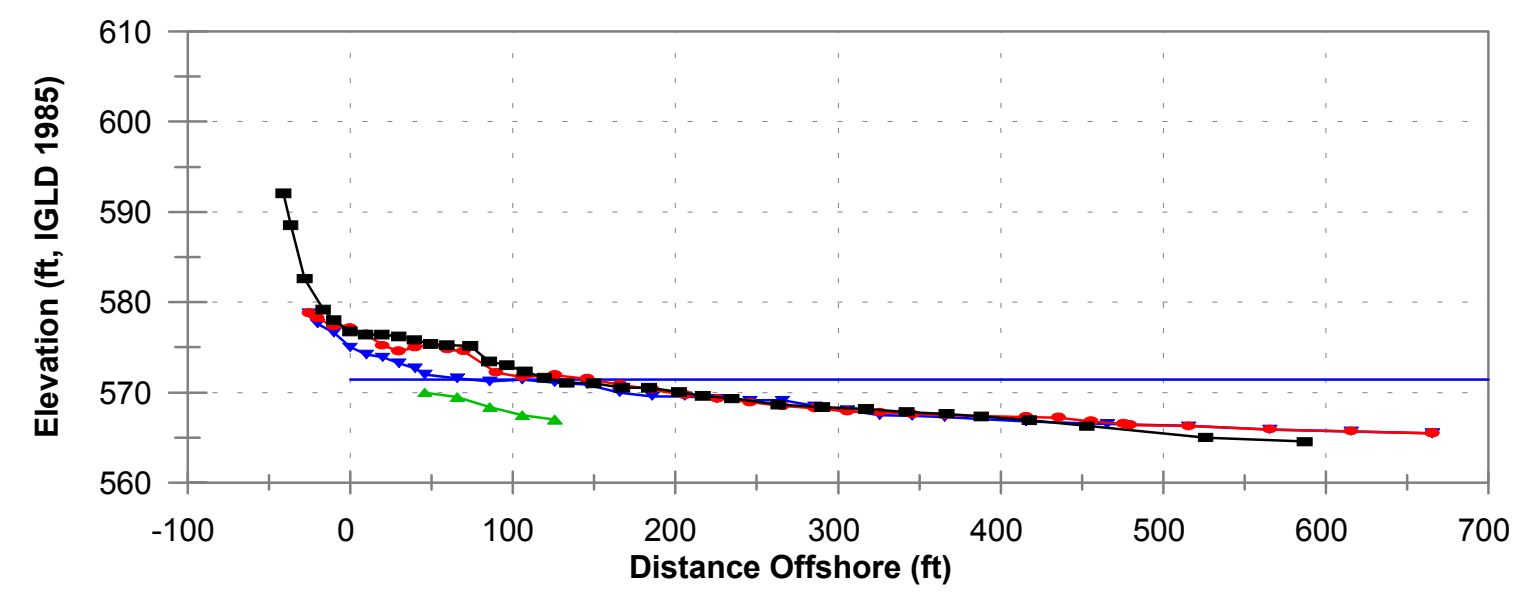

Sep 99 WL

W225 5-30-90 Pre-project

$\longrightarrow$ W225 12-4-91

$\multimap$ W225 9-16-92

$\longrightarrow$ W225 9-24-99 

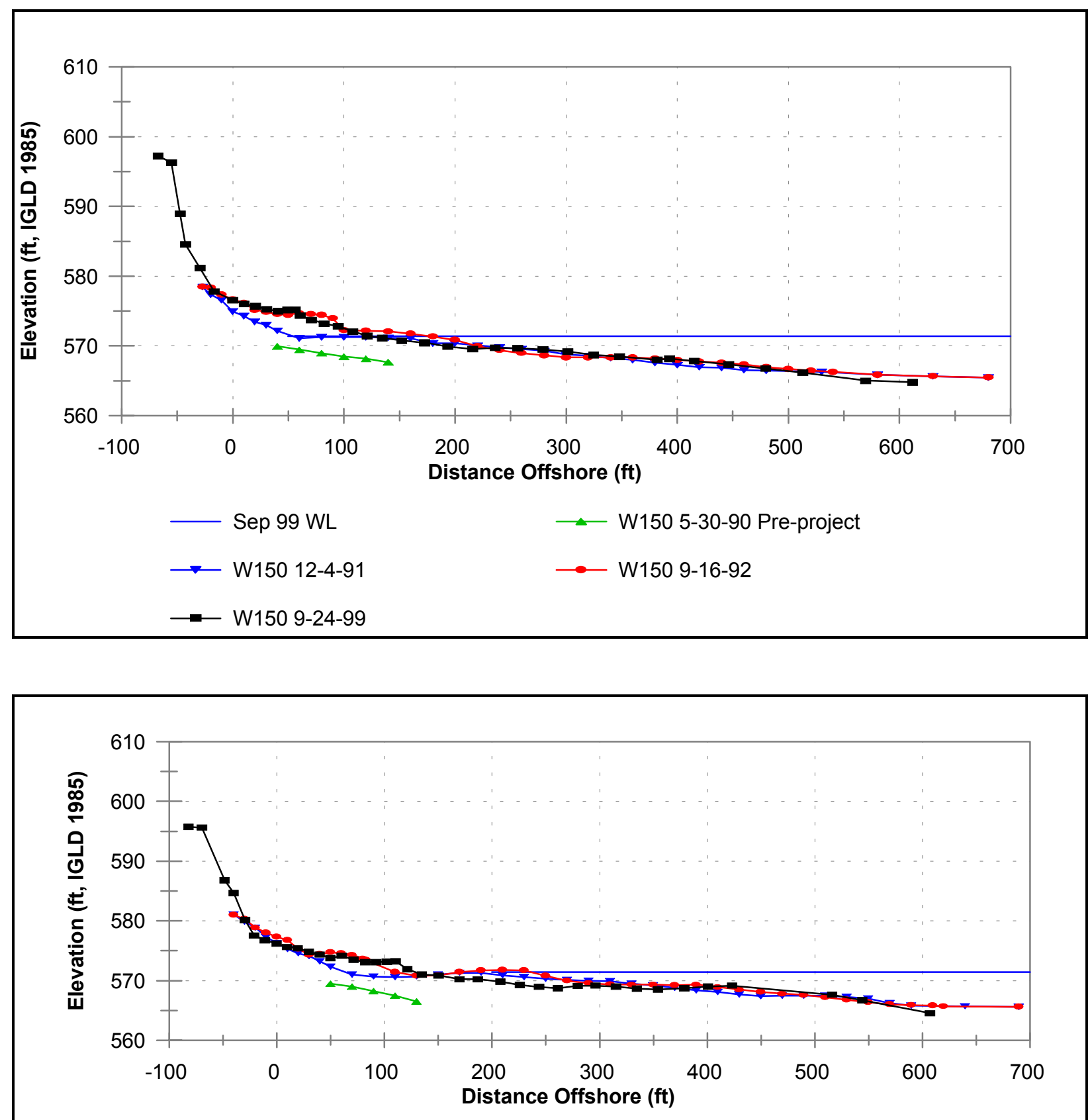

Sep 99 WL

W075 5-30-90 Pre-project

$\longrightarrow$ W075 12-4-91

$\multimap$ W075 9-16-92

$\longrightarrow-$ W075 9-24-99 


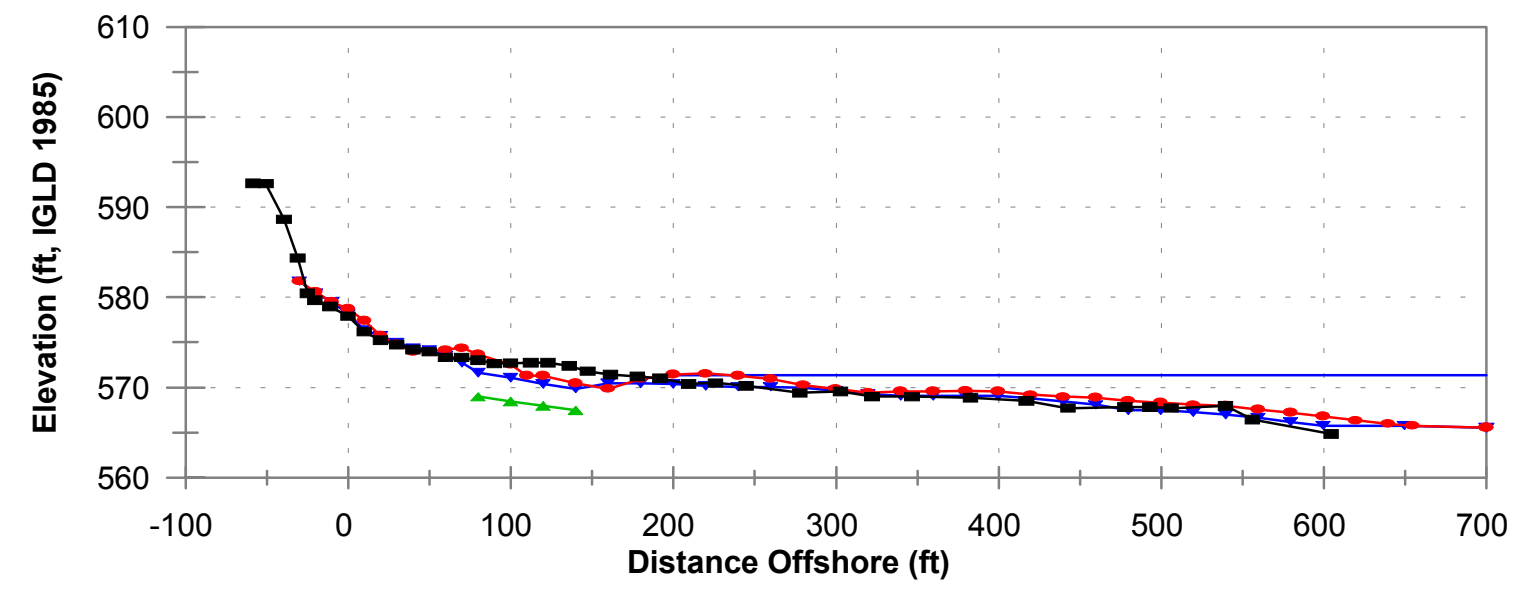

— Sep $99 \mathrm{WL}$

— W025 5-30-90 Pre-project

$\longrightarrow$ W025 12-4-91

$\because$ W025 9-16-92

$\rightarrow$ W025 9-24-99

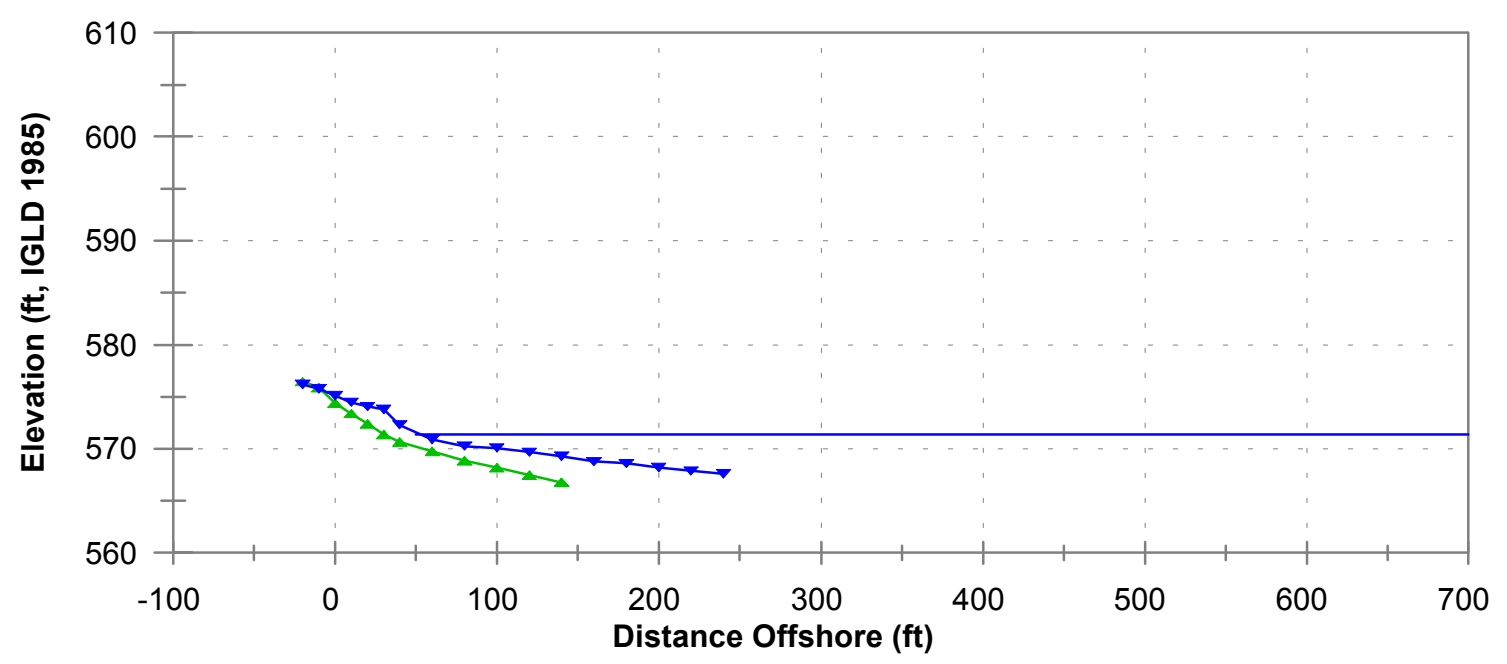

Sep 99 WL

—E675 5-30-90 Pre-project

$\longrightarrow$ E675 10-24-91 

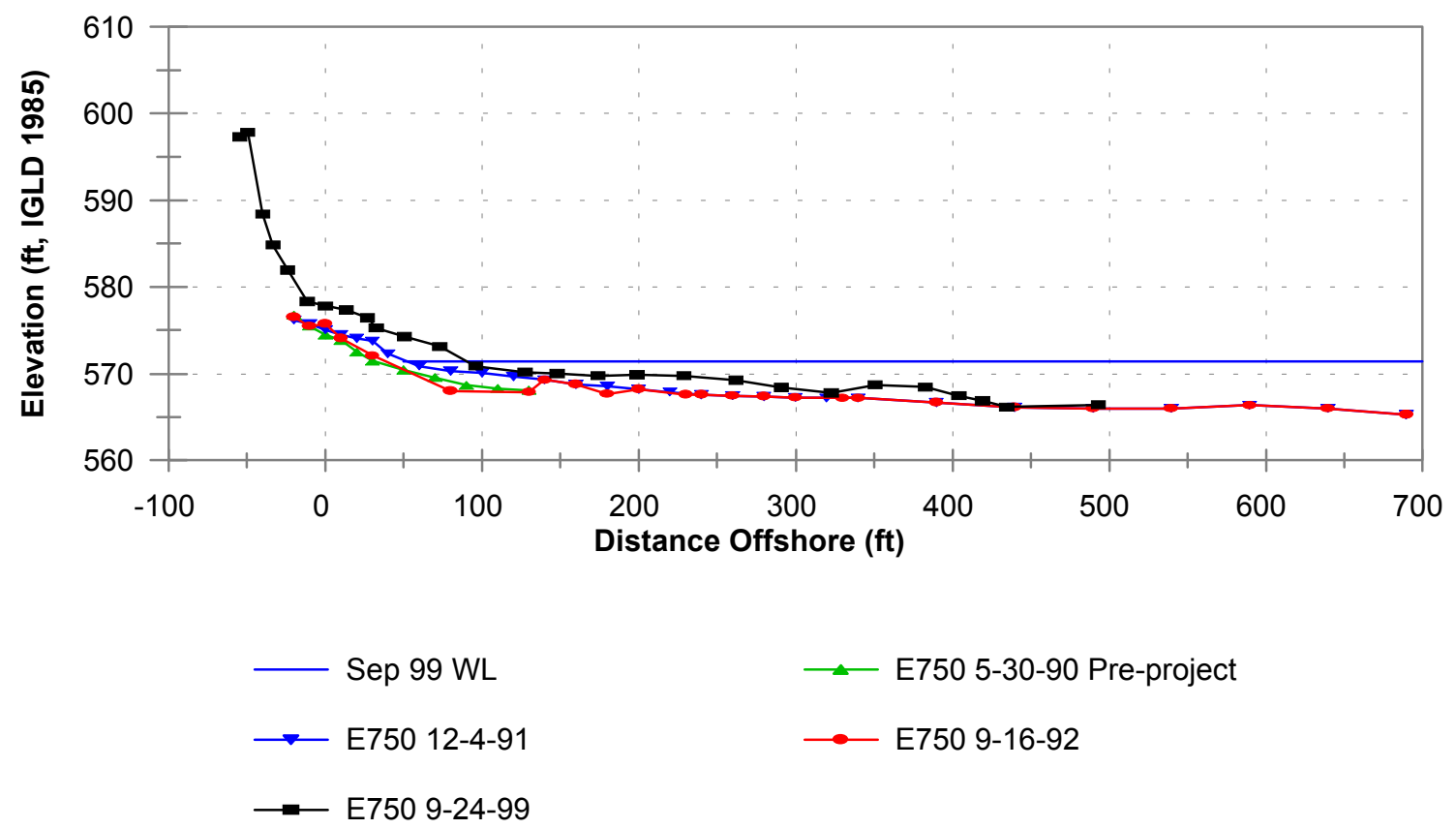

—E750 5-30-90 Pre-project

$\because$ E750 9-16-92

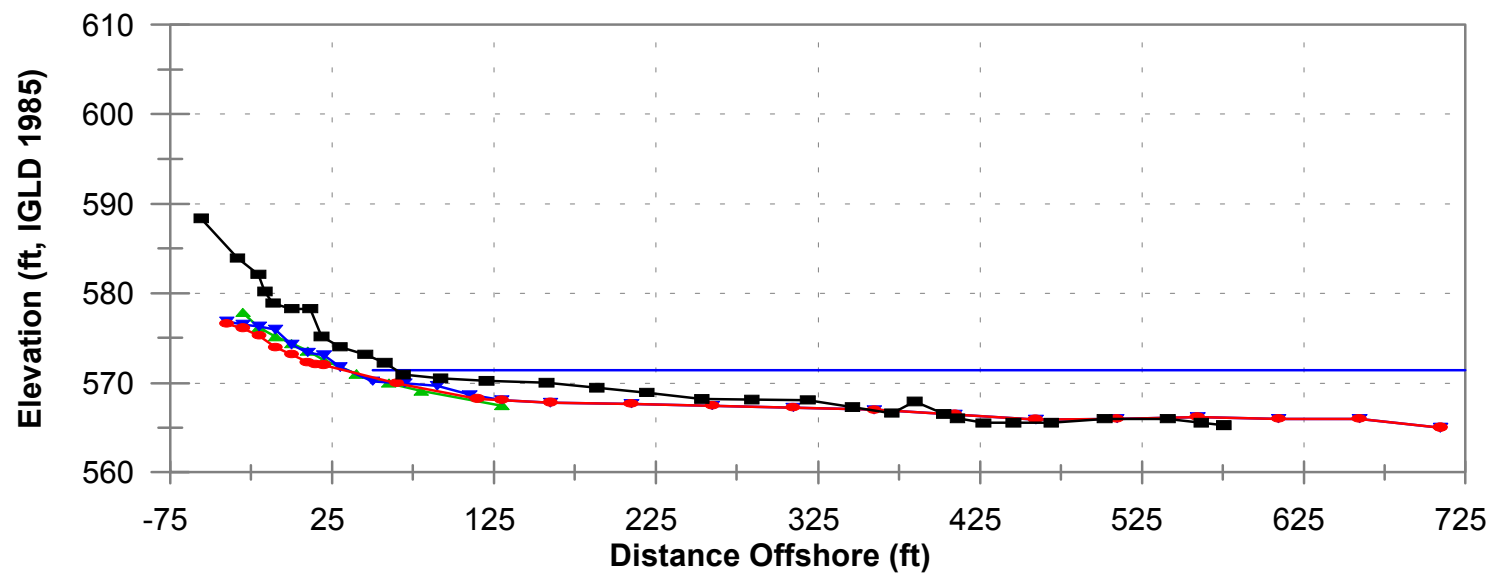

— Sep $99 \mathrm{WL}$

E825 5-30-90 Pre-project

$\longrightarrow$ E825 12-4-91

$\longrightarrow$ E825 9-16-92 

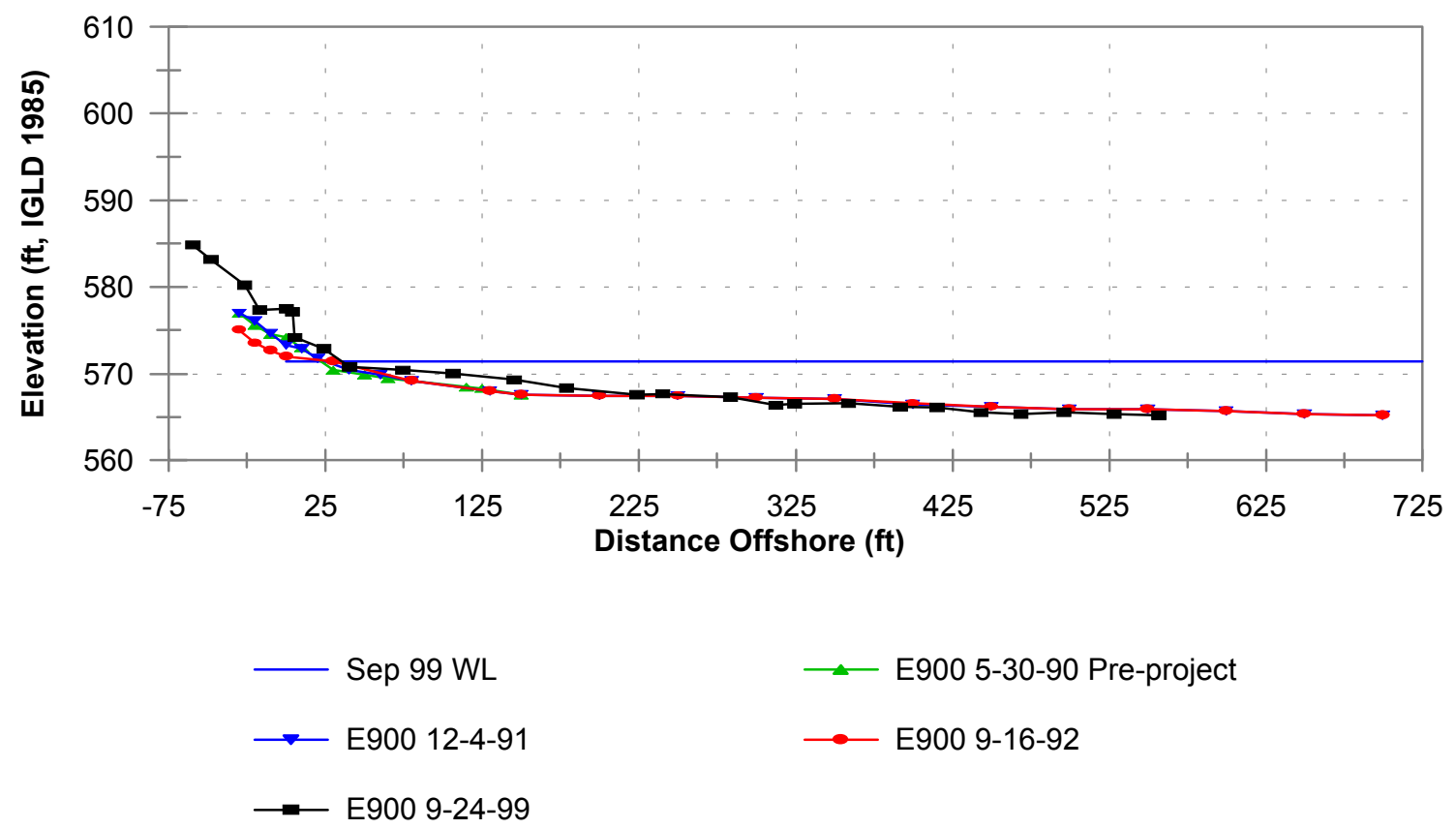

—E900 5-30-90 Pre-project

—E900 9-16-92

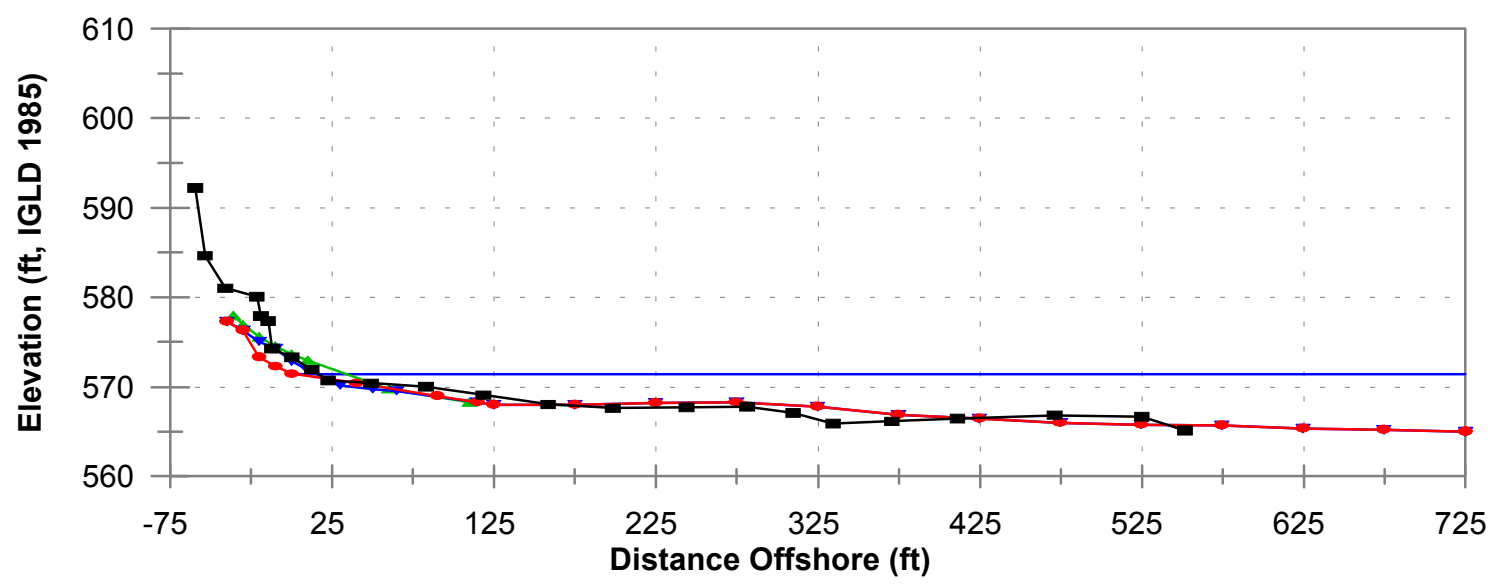

— Sep $99 \mathrm{WL}$

E975 5-30-90 Pre-project

$\longrightarrow$ E975 12-4-91

$\longrightarrow$ E975 9-16-92

$\longrightarrow$ E975 9-24-99 

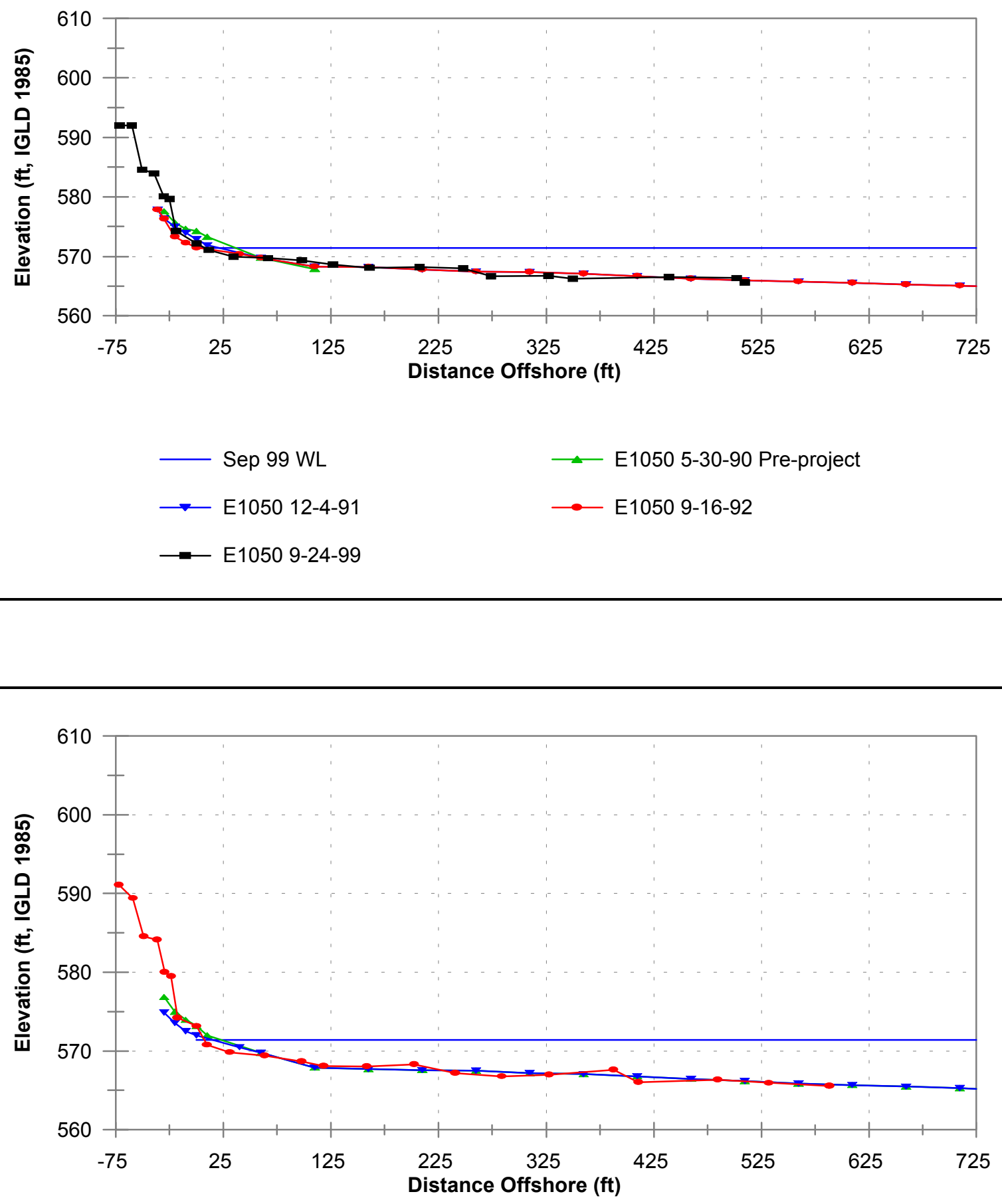

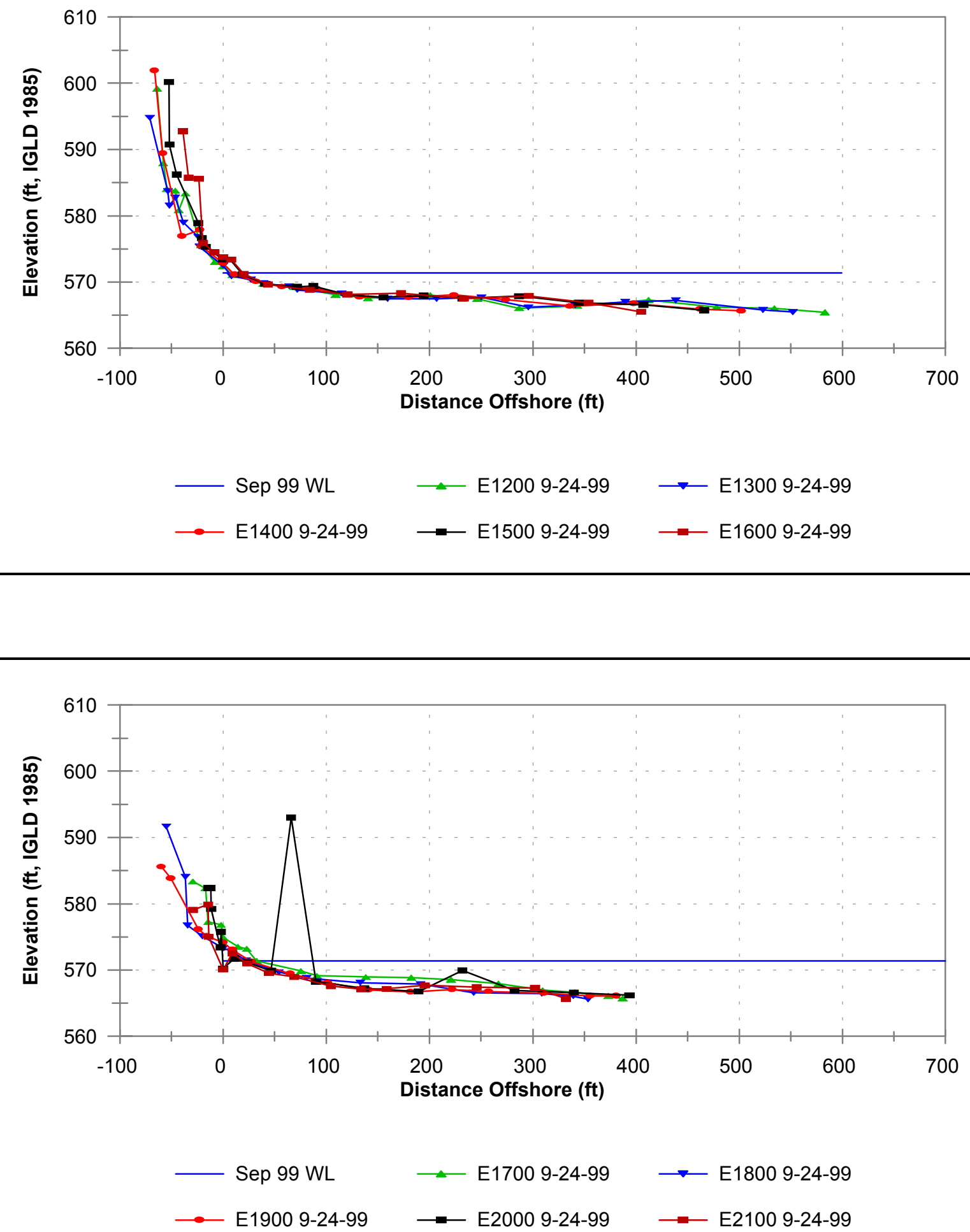


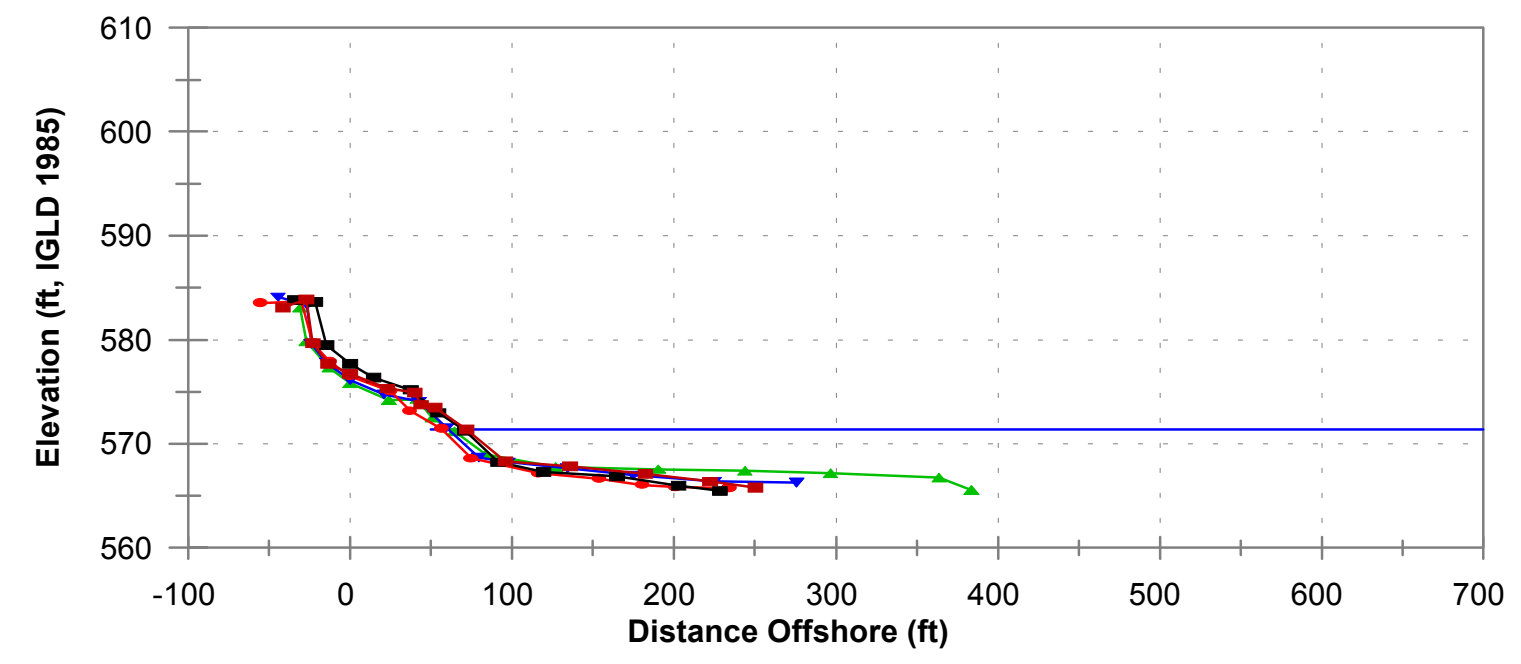

- Sep $99 \mathrm{WL} \longrightarrow$ E2700 9-24-99 $\longrightarrow$ E2800 9-24-99

$\multimap$ E2900 9-24-99 — E3000 9-24-99 —- E3100 9-24-99

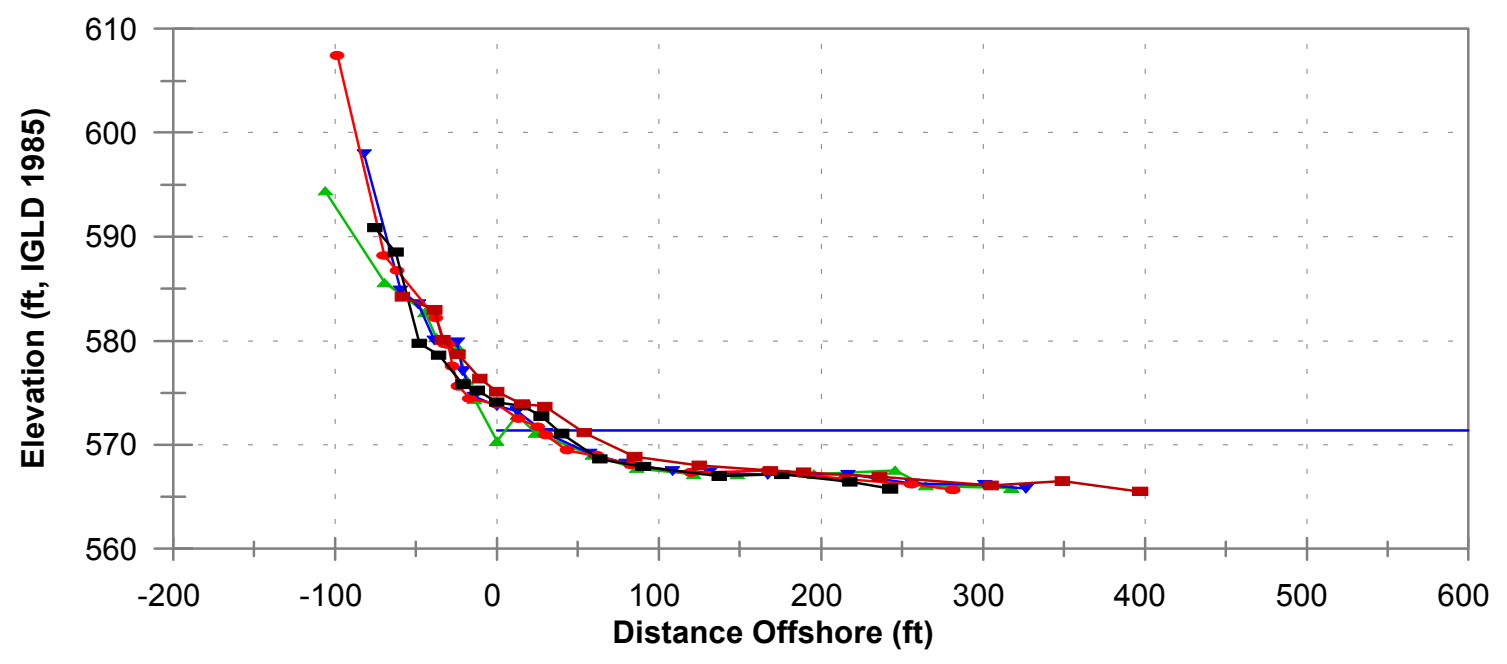

- Sep $99 \mathrm{WL} \longrightarrow$ E2200 9-24-99 $\longrightarrow$ E2300 9-24-99

$\multimap$ E2400 9-24-99 — E2500 9-24-99 —- E2600 9-24-99 


\section{Appendix D \\ Profile Survey Procedures and Establishment of Baseline ${ }^{1}$}

\section{Baseline}

The 1991 baseline was re-established from the original found rebar pins set by Lynn S. Hofius on Sightsinger Road, which were used for a "construction baseline", having a project bearing of North 48 degrees 12 minutes East. A rebar was set near the 1991 boundary line, 100 feet from the westernmost Hofius pin. The cross-section base line was re-set at 120 feet from the "construction baseline" and at an angle of 90 degrees from the found pins towards the lake. Two P.K. nails were set in the marina asphalt lot at baseline stations E $0+75$ and E $6+75$. The original baseline was re-created going west from stations $\mathrm{W} 0+25$ (hub) to W $3+00$ (rebar/cap) along the project bearing of North 53 degrees 14 minutes East. The baseline was then extended at 100-foot increments along two random lines from W $3+00$ to $\mathrm{W} 10+00$ (rebar/cap) and to $\mathrm{W} 12+00$ (rebar/cap). The original baseline was re-created going east from E 6+75 (PK) to $\mathrm{E} 11+25$ (rebar/cap) setting a rebar at E 8+25, along the project bearing of North 55 degrees 42 minutes East. The baseline was then extended 75 feet to E $12+00$ then at 100-foot intervals along four random lines from E $12+00$ to E $16+25$ (rebar/cap), from E $16+25$ to E $19+21.18$ (rebar/cap), from E 19+21.18 to $\mathrm{E} 30+51.12$ (rebar/cap), setting a rebar at E 25+00, then from E 30+51.12 to 20 Mile Creek, setting a rebar at E $32+00$.

\section{Vertical Control}

A level loop was made from USC\&GS Station "ORTON" located at I-90/U.S. 20 Interchange 12, about 3 miles southeast of North East Marina.

\footnotetext{
${ }^{1}$ The following text are exerts taken from Project Summary Sheet submitted to U.S. Army Engineer District, Pittsburgh, by GRW Aerial Surveys, Inc., 801 Corporate Drive, Lexington, KY 40503 .
} 
Vertical control was referenced to the International Great Lakes Datum of 1985 (IGLD-85) by using the published Dynamic Height and applying a Hydraulic Correction of +0.08 feet. Bench marks were set at one-half mile intervals. An elevation check was made on the Hofius Bench Mark on Sightsinger Road (0.23 ') and on "TBM 10" (-0.32') a previously set elevation point on the east marina wall. Elevations were established on all baseline stations and on two GPS stations named "GPS EAST and GPS WEST".

\section{Horizontal Control}

Horizontal control was referenced to the NAD 83 Pennsylvania State Plane Coordinates- North Zone, in U.S. Survey Feet, from GPS observations made to B-Order HARN USC\&GS Station "M 56" in Chautauqua County, New York near the town of Ripley and New York Department of Transportation Station "FRENCH CREEK" located on the abutment of State Route 430 over French Creek, about 4.4 miles south of the town of Findley Lake in Chautauqua County, New York. GPS observations were made to two on site stations named "GPS EAST and GPS WEST".

Both stations were one-half inch rebar, 24 inches long with plastic GRWAS yellow plastic cap. They were set as an inter-visible pair near the east and west property lines, near the cyclone fences, south of the marina office building, at the top of the bluff along the parking lot access roads. Reference sketches accompany this report. A horizontal traverse tie was made to the Hofius rebars and the set rebar near the property line, which was the basis for the original base line.

The field re-establishment of the original baseline and all station crosssection/profiles were based on an assumed coordinate system (N5000,E5000 on Hofius rebar at $100^{\prime}$ ) and referenced to the original "construction baseline" bearing of North 48 degrees 12 minutes East. The field collected data was translated and rotated to NAD 83 coordinates after GPS processing and adjustment, as an office procedure and named "NE-NAD83.CR2". The field collected cross-section data was also translated and rotated so that the northing coordinate was near N 0.00 and the easting coordinate was the distance from the baseline station and named "NE-XS.CR3". This file was used in the generation of the cross-section plots from "Microsoft Excel".

\section{Cross Sections}

All original cross-sectional lines were run relative to the 1991 survey. New base line station cross-sections were designed to be measured parallel to the original survey lines. Baseline stations with elevations were occupied with a Topcon total station and sections measured using standard trig-elevation 
$\mathrm{rod} / \mathrm{prism}$ configuration methods. Lines were taken to the top of the bluff and into the lake as far as possible, generally to the 566 elevation.

\section{Profile Monuments (extracted from complete data listing) ${ }^{1}$}

\begin{tabular}{|c|c|c|c|c|}
\hline \multicolumn{5}{|c|}{$\begin{array}{l}\text { Table D1 } \\
\text { Profile Survey Control Monuments, September } 1999 \text { Field Study }\end{array}$} \\
\hline Point no. & Northing $^{1}$ & Easting $^{1}$ & Elevation $^{2}$ & Description \\
\hline 1 & 768249.799 & 1415162.690 & 598.290 & IPC HOFIUS \\
\hline 2 & 768281.845 & 1415201.070 & 0.000 & IPC HOFIUS \\
\hline 3 & 768313.891 & 1415239.451 & 0.000 & IPC GRWAS \\
\hline 4 & 768406.003 & 1415162.540 & 0.000 & STA $0+00 \mathrm{BL}$ \\
\hline 5 & 768838.618 & 1415680.684 & 576.820 & PT5 E 6+75 BL \\
\hline 6 & 768454.067 & 1415220.122 & 578.870 & PT6 E 0+75 BL \\
\hline 7 & 768838.563 & 1415680.754 & 0.000 & CK PT 5 \\
\hline 8 & 768872.012 & 1415680.477 & 0.000 & CHISHELD X \\
\hline 9 & 768901.215 & 1415657.819 & 0.000 & LEAD PLUG \\
\hline 10 & 768788.075 & 1415679.315 & 0.000 & PK NAIL BL \\
\hline 11 & 768439.509 & 1415253.836 & 0.000 & PK MARINA BL \\
\hline 12 & 768454.548 & 1415170.766 & 0.000 & CHISLED $X$ \\
\hline 13 & 768492.706 & 1415132.774 & 0.000 & LEAD PLUG \\
\hline 14 & 768830.692 & 1414856.409 & 0.000 & LEAD PLUG \\
\hline 15 & 769269.590 & 1415442.956 & 0.000 & LEAD PLUG HOFIUS \\
\hline 16 & 768391.669 & 1415141.936 & 577.920 & STA W0+25 \\
\hline 17 & 768363.005 & 1415100.736 & 576.220 & STA W0+75 \\
\hline 18 & 768320.007 & 1415038.932 & 576.590 & STA W1+50 \\
\hline 19 & 768277.014 & 1414977.137 & 576.790 & STA W2+25 \\
\hline 20 & 768234.003 & 1414915.316 & 577.810 & PI STA W3+00 \\
\hline 21 & 768879.109 & 1415744.585 & 577.840 & STA E7+50 \\
\hline & & & & (Contin \\
\hline
\end{tabular}

\footnotetext{
1 The complete data set is available from the Survey Branch, U.S. Army Engineer District, Pittsburgh.
} 


\begin{tabular}{|c|c|c|c|c|}
\hline \multicolumn{5}{|c|}{ Table D1 (Concluded) } \\
\hline Point no. & Northing $^{1}$ & Easting $^{1}$ & Elevation $^{2}$ & Description \\
\hline 22 & 768919.595 & 1415808.478 & 578.290 & STA E8+25 \\
\hline 23 & 768960.087 & 1415872.379 & 577.540 & STA E9+00 \\
\hline 24 & 769000.577 & 1415936.281 & 573.330 & STA E9+75 \\
\hline 25 & 769041.069 & 1416000.182 & 572.210 & STA E10+50 \\
\hline 26 & 769079.494 & 1416060.654 & 573.180 & STA E11+25 IPC \\
\hline 27 & 769373.642 & 1416464.984 & 574.150 & STA E16+25 IPC \\
\hline 28 & 769358.933 & 1416444.765 & 573.760 & STA E16+00 HUB \\
\hline 29 & 769241.311 & 1416283.085 & 572.870 & STA E14+00 HUB \\
\hline 30 & 769182.530 & 1416202.285 & 572.520 & STA E13+00 HUB \\
\hline 31 & 769123.671 & 1416121.313 & 572.430 & STA E12+00 HUB \\
\hline 32 & 769300.163 & 1416363.920 & 573.420 & STA $15+00$ HUB \\
\hline 33 & 769081.555 & 1416064.074 & 88.010 & STA E11+25 \\
\hline 34 & 768075.968 & 1414660.386 & 579.610 & PI STA W6+00 HUB \\
\hline 35 & 768013.231 & 1414582.506 & 578.220 & STA W7+00 \\
\hline 36 & 767950.440 & 1414504.551 & 577.590 & STA W8+00 \\
\hline 37 & 767887.781 & 1414426.776 & 576.590 & STA W9+00 \\
\hline 38 & 767825.016 & 1414348.722 & 577.040 & PI STA W10+00 \\
\hline 39 & 768128.635 & 1414745.345 & 579.510 & STA W5+00 \\
\hline 40 & 768181.332 & 1414830.352 & 579.060 & STA W4+00 \\
\hline 1317 & 769398.147 & 1416535.820 & 574.960 & STA E17+00 \\
\hline 1318 & 769430.841 & 1416630.318 & 573.310 & STA E18+00 \\
\hline 1319 & 769463.555 & 1416724.892 & 574.170 & STA E19+00 \\
\hline 1320 & 769518.393 & 1416809.923 & 573.480 & STA E $20+00$ \\
\hline 1321 & 769577.691 & 1416890.399 & 573.370 & STA E21+00 \\
\hline 1322 & 769636.975 & 1416970.856 & 573.600 & STA E22+00 \\
\hline 1323 & 769696.357 & 1417051.448 & 573.700 & STA E23+00 \\
\hline 1324 & 769755.667 & 1417131.900 & 573.910 & STA E24+00 \\
\hline 1325 & 769815.005 & 1417212.424 & 574.110 & STA E25+00 IPC \\
\hline 1326 & 769873.125 & 1417291.293 & 575.130 & STA E26+00 \\
\hline 1327 & 769932.449 & 1417371.796 & 575.860 & STA E27+00 \\
\hline 1328 & 769991.864 & 1417452.423 & 576.130 & STA E28+00 \\
\hline 1329 & 770051.089 & 1417532.793 & 576.520 & STA E29+00 \\
\hline 1330 & 770110.468 & 1417613.370 & 577.690 & STA E30+00 \\
\hline 1331 & 770187.576 & 1417668.996 & 576.730 & STA E31+00 \\
\hline 1332 & 770283.113 & 1417698.552 & 575.720 & STA E32+00 \\
\hline
\end{tabular}




\section{Appendix E}

\section{Field Notes from 10 October 1999 Data Collection Effort ${ }^{1}$}

\section{Sta W $0+75$}

Water's Edge (W.E.) $160 \mathrm{ft}$ from baseline. Steel probe driven $5 \mathrm{ft}$. into sand to refusal (bedrock?). $100 \mathrm{ft}$. from W.E. - $1.5 \mathrm{ft}$. water depth. Probe pushed through $3 \mathrm{ft}$. of fine to medium sand to refusal. $200 \mathrm{ft}$. from W.E. - $3.0 \mathrm{ft}$. water depth. Probe pushed through $2.8 \mathrm{ft}$. of sand to refusal. $300 \mathrm{ft}$. from W.E. - 3.5 $\mathrm{ft}$. water depth. Probe pushed through $1.5 \mathrm{ft}$. if sand to refusal. $400 \mathrm{ft}$. from W.E. $-6.0 \mathrm{ft}$ water depth. 3 inch sand cover over hard shale. $500 \mathrm{ft}$. from W.E. $-6.8 \mathrm{ft}$. water depth. No sand - cobble bottom. Video taken by divers. $700 \mathrm{ft}$. from W.E. $-7.7 \mathrm{ft}$ water depth. No sand - cobble bottom. Divers videotaped back toward shore along the station alignment.

\section{Sta. W $2+25$}

W.E. $120 \mathrm{ft}$. from baseline. Steel probe driven $4 \mathrm{ft}$. to bedrock to refusal (bedrock). $100 \mathrm{ft}$. from W.E. $-1.5 \mathrm{ft}$. water depth. Probe pushed $3.5 \mathrm{ft}$. to shale. $200 \mathrm{ft}$. from W.E. $-3 \mathrm{ft}$. water depth. Probe pushed $1.5 \mathrm{ft}$. to refusal. $300 \mathrm{ft}$. from W.E. $-4.5 \mathrm{ft}$. water depth. Probe pushed $1.2 \mathrm{ft}$. to shale. $400 \mathrm{ft}$ from W.E. $-6.5 \mathrm{ft}$. water depth. No sand - cobble bottom. $500 \mathrm{ft}$. from W.E. $-6.5 \mathrm{ft}$. water depth. No sand - cobble bottom. Video taken by hanging camera from boat and taping back towards shore starting at $500 \mathrm{ft}$. from W.E. Further use of scuba divers was determined to be unnecessary due to clear water and ability to obtain data and video from boat deck and by wading.

\section{Sta. W 8+00}

W.E. $60 \mathrm{ft}$. from baseline. Steel probe driven 18" to refusal (bedrock). $100 \mathrm{ft}$. from W.E. $-4.0 \mathrm{ft}$. water depth. 6 inches of sand to shale. $200 \mathrm{ft}$, from W.E. -

\footnotetext{
1 Adopted from Mr. Thomas Bender, U.S. Army Engineer District, Buffalo. (Non-SI units are used. To convert feet to meters, mutilpy by 0.3048 . To convert inches to centimeters, multiply by 2.54)
} 
$6 \mathrm{ft}$. water depth - hard shale bottom. $300 \mathrm{ft}$. from W.E. $-6 \mathrm{ft}$. water depth hard shale bottom. Video taken back towards shore by suspending camera from boat deck.

\section{Lakeward of marina - approx. $100 \mathrm{ft}$. east of west corner}

Cobble bottom at base of armor stone in $3-4 \mathrm{ft}$. of water extending approx. 25 $\mathrm{ft}$. lakeward. Thin veneer of sand ripples over hard shale bottom visible for next $25 \mathrm{ft}$. $6 \mathrm{ft}$. water depth $50 \mathrm{ft}$. from breakwater Clean hard shale visible for next $200 \mathrm{ft}$. Video taken for $100 \mathrm{ft}$. toward shore.

\section{Lakeward of marina - approx. $100 \mathrm{ft}$. west of east corner}

Cobble bottom at base of armor stone in 3-4 ft. of water extending approx. $25 \mathrm{ft}$. lakeward. Only traces of sand visible for next $25 \mathrm{ft}$. $6 \mathrm{ft}$. water depth at $50 \mathrm{ft}$. from breakwater. Clean hard bedrock for next $150 \mathrm{ft}$. - no evidence of sand. Video taken back towards shore for approx. $100 \mathrm{ft}$.

\section{Point approx. $1 / 2 \mathrm{mi}$. west of marina}

Clean hard shale bottom approx. $600 \mathrm{ft}$. offshore extending to approx. $100 \mathrm{ft}$. from shore. Scattered cobbles on hard shale bottom to waters edge. Some sand between cobbles from $50 \mathrm{ft}$. offshore to waters edge.

\section{Sta. E $7+50$}

W.E. $93 \mathrm{ft}$. from baseline. Steel probe driven $3 \mathrm{ft}$. to refusal (bedrock?). $100 \mathrm{ft}$. from W.E - $2 \mathrm{ft}$. water depth. Probe pushed $2 \mathrm{ft}$. to refusal. $200 \mathrm{ft}$. from W.E. $2.5 \mathrm{ft}$. water depth. 6 inches of sand to bedrock. 4-inch to 6-inch cobble bottom from 250 to $300 \mathrm{ft}$. from W.E. $4.0 \mathrm{ft}$. water depth at $300 \mathrm{ft}$. from shore -1.5 $\mathrm{ft}$.of sand over shale bottom near south side of entrance channel. $400 \mathrm{ft}$. from W.E (approx. $25 \mathrm{ft}$. from east end of outer breakwater - $5.5 \mathrm{ft}$. water depth cobble tip shoal then bare rock adjacent to shoal. $500 \mathrm{ft}$. from W.E. $-5.5 \mathrm{ft}$. water depth - hard shale bottom. Video taken back towards shore.

\section{Sta. E 9+00}

W.E. $36 \mathrm{ft}$. from baseline. Steel probe pushed $1 \mathrm{ft}$. to refusal (bedrock). $100 \mathrm{ft}$. from W.E. $-2.4 \mathrm{ft}$. water depth $-1.0 \mathrm{ft}$. sand cover over shale. $200 \mathrm{ft}$. from W.E. - 3ft. water depth - hard shale bottom. $300 \mathrm{ft}$. from shore $-4.5 \mathrm{ft}$. water depth - hard shale bottom. $400 \mathrm{ft}$. from W.E. $-5.5 \mathrm{ft}$. water depth - hard shale bottom. $500 \mathrm{ft}$. from W.E. $-5.5 \mathrm{ft}$. water depth - hard shale bottom. Video taken back towards shore. 


\section{Sta. E 11+00}

W.E. $10 \mathrm{ft}$. from baseline. $0.5 \mathrm{ft}$. sand cover over bedrock. $100 \mathrm{ft}$. from W.E. $3 \mathrm{ft}$. water depth -2 inch sand cover. $200 \mathrm{ft}$. from W.E. $-3 \mathrm{ft}$. water depth hard shale bottom. $300 \mathrm{ft}$. from baseline $-5 \mathrm{ft}$. water depth - hard shale bottom. $400 \mathrm{ft}$. from W.E. - $4 \mathrm{ft}$. water depth - hard shale bottom. Video taken back towards shore. 


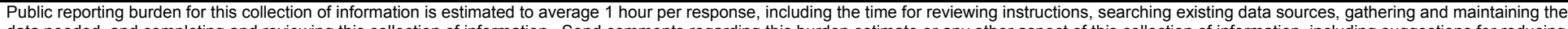

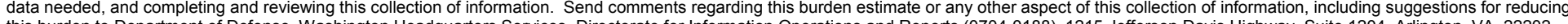

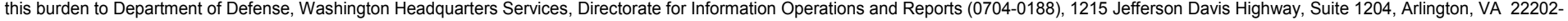

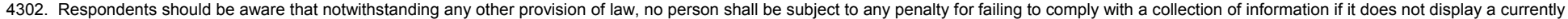
valid OMB control number. PLEASE DO NOT RETURN YOUR FORM TO THE ABOVE ADDRESS.

\begin{tabular}{l|l|l|l} 
1. REPORT DATE (DD-MM-YYYY) & 2. REPORT TYPE & 3. DATES COVERED (FrOm - To)
\end{tabular}

June 2001

Final Report

4. TITLE AND SUBTITLE

Beach Erosion and Sediment Processes Study, North East Marina,

Erie County, Pennsylvania

5a. CONTRACT NUMBER

Andrew Morang, Jeffrey Melton

5b. GRANT NUMBER

5c. PROGRAM ELEMENT NUMBER

5d. PROJECT NUMBER

5e. TASK NUMBER

5f. WORK UNIT NUMBER

8. PERFORMING ORGANIZATION REPORT NUMBER

U.S. Army Engineer Research and Development Center

Coastal and Hydraulics Laboratory

ERDC/CHL TR-01-12

3909 Halls Ferry Road

Vicksburg, MS 39180-6199

9. SPONSORING / MONITORING AGENCY NAME(S) AND ADDRESS(ES)

10. SPONSOR/MONITOR'S ACRONYM(S)

U.S. Army Engineer District, Pittsburgh

William Moorhead Federal Building

1000 Liberty Avenue

Pittsburgh, PA 15222-4186

11. SPONSOR/MONITOR'S REPORT NUMBER(S)

\section{DISTRIBUTION / AVAILABILITY STATEMENT}

Approved for public release; distribution is unlimited.

\section{SUPPLEMENTARY NOTES}

\section{ABSTRACT}

North East Marina is a recreational boating facility on the shore of Lake Erie in the northwestern corner of Pennsylvania. Since construction in 1991, artificial bypassing has been conducted to maintain the movement of sediment along the coast from west to east, but downdrift homeowners complained that their beaches had eroded excessively. The purpose of this study was to identify and investigate alternative solutions to the beach erosion problem in the vicinity of the marina. Based on cross-shore profile surveys, since November of

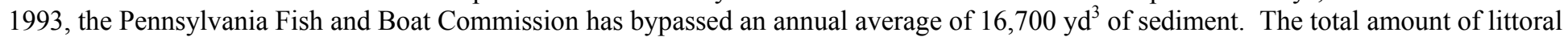
material bypassed from 1991 to 2001 has been about 105,000 $\mathrm{yd}^{3}$. This volume approximately equals the natural drift along this shore. The width of the dry beach is largely a function of lake water level. At this time, continued bypassing is the optimum solution, and no structural solutions are recommended. Hydraulic bypassing is not practical here because of gravel and freezing conditions. Mechanical bypassing will have to be continued indefinitely, and annual volumes will have to be adjusted based on sediment accumulates on the updrift fillet.

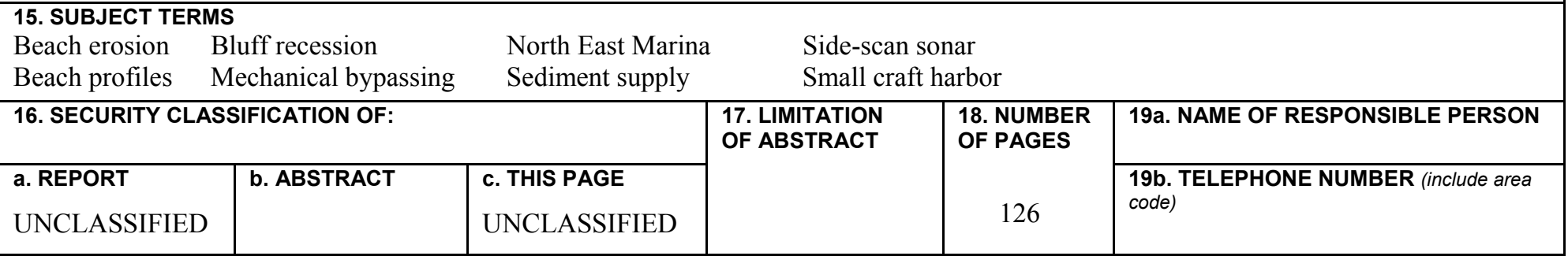

